\title{
Copper imbalance in Alzheimer's disease: Convergence of the chemistry and the clinic
}

\author{
Kepp, Kasper P.; Squitti, Rosanna
}

Published in:

Coordination Chemistry Reviews

Link to article, DOI:

10.1016/j.ccr.2019.06.018

Publication date:

2019

Document Version

Peer reviewed version

Link back to DTU Orbit

Citation (APA):

Kepp, K. P., \& Squitti, R. (2019). Copper imbalance in Alzheimer's disease: Convergence of the chemistry and the clinic. Coordination Chemistry Reviews, 397, 168-187. https://doi.org/10.1016/j.ccr.2019.06.018

\section{General rights}

Copyright and moral rights for the publications made accessible in the public portal are retained by the authors and/or other copyright owners and it is a condition of accessing publications that users recognise and abide by the legal requirements associated with these rights.

- Users may download and print one copy of any publication from the public portal for the purpose of private study or research.

- You may not further distribute the material or use it for any profit-making activity or commercial gain

- You may freely distribute the URL identifying the publication in the public portal

If you believe that this document breaches copyright please contact us providing details, and we will remove access to the work immediately and investigate your claim. 
Copper imbalance in Alzheimer's disease: Convergence of the chemistry and the clinic Kasper P. Kepp ${ }^{1 *}$ and Rosanna Squitti ${ }^{2 *}$

${ }^{1}$ Technical University of Denmark, DTU Chemistry, Denmark

${ }^{2}$ IRCCS Istituto Centro San Giovanni di Dio Fatebenefratelli, Brescia, Italy

Correspondence:

KPK: kpj@kemi.dtu.dk

Technical University of Denmark, DTU Chemistry, DK-2800 Kongens Lyngby, Denmark.

Phone: +45 45252409 .

RS: rosanna.squitti@afar.it

IRCCS Istituto Centro San Giovanni di Dio- Fatebenefratelli, 25125 Brescia, Italy.

Phone: 0039-030-3501725.

\section{Content}

1. Introduction

2. The amyloid hypothesis and its main problems

3. Brain copper homeostasis

4. The critical $\mathrm{K}_{\mathrm{d}}$ of CuAD

5. Clinical evidence: Copper dyshomeostasis in AD

6. Biochemical evidence: $A P P / A \beta$ and copper transport

7. Molecular mechanisms of copper toxicity in CuAD

8. Analogies to other Cu-related diseases

9. Combining the facts into a simple model of AD due to copper dyshomeostasis

10. Conclusions 


\begin{abstract}
In this perspective we list the many clinical, histopathological, genetic and chemical observations relating copper to Alzheimer's disease (AD). We summarize how the coordination chemistry of the APP/A $\beta$ system is centrally involved in neuronal copper transport at the synapses, and that genetic variations in the gene coding for the copper transporter ATP7B cause a subset of AD, which we call CuAD. Importantly, the distinction between loss of function and gain of toxic function breaks down in CuAD, because copper dyshomeostasis features both aspects directly. We argue that $\mathrm{CuAD}$ can be described by a single control variable, a critical, location-dependent copper dissociation constant, $\mathrm{K}_{\mathrm{d}}{ }^{\mathrm{c}}$. Loss of functional copper from protein-bound pools reduces energy production and oxidative stress control and is characterized by a reduced pool of divalent $\mathrm{Cu}(\mathrm{II})$ with $\mathrm{K}_{\mathrm{d}}<\mathrm{K}_{d}{ }^{\mathrm{c}}$. Gain of redox-toxic function is described by more copper with $\mathrm{K}_{d}>\mathrm{K}_{d}{ }^{\mathrm{c}}$. In the blood, the critical threshold is estimated to be $\mathrm{K}_{\mathrm{d}}{ }^{\mathrm{c}} \sim 10^{-12} \mathrm{M}$ whereas at synapses it is argued to be $\mathrm{K}_{\mathrm{d}}^{\mathrm{c}} \sim 10^{-9} \mathrm{M}$. The synaptic threshold is close to the values of $\mathrm{K}_{\mathrm{d}}$ for $\mathrm{Cu}(\mathrm{II})$-binding to $\mathrm{A} \beta$, prion protein, APP, and $\alpha$-synuclein, implied in copper buffering at the synapses during glutamatergic transmission. The empirical support for and biochemical and pathological consequences of $\mathrm{CuAD}$ are discussed in detail.
\end{abstract}

Keywords: Alzheimer's disease; copper; $\beta$-amyloid; $K_{d}$, ceruloplasmin; ATP7B 


\section{Introduction}

Every day, thousands of people across the world are estimated to develop Alzheimer's Disease (AD)[1,2]. Despite its enormous prevalence and tragic consequences, currently available treatments only delay the disease by typically a few months[3,4], and the many recent failures of leading drug candidates have put renewed emphasis on alternative, more complete causal disease mechanisms[5-10]. The disease manifests first as mild cognitive impairment characterized by a gradual loss of episodic memory and leads to a slow, continuous impairment of cognitive abilities and life quality[3,11-13]. Neuron loss initiates in the cerebral cortex and commonly in the hippocampus[14].

Diagnosis of $\mathrm{AD}$ requires the observation of deposits of senile plaques outside the neurons and neurofibrillar tangles inside neurons[12,13]. The plaques contain oxidized and metal-bound $\beta$-amyloid $(\mathrm{A} \beta)$ peptides arranged in regular $\beta$-sheet fibril structures[15-17]. AD occurs most commonly with no apparent family history as "sporadic AD" (SAD); only a very small percentage relates to inherited mutations within a family, i.e. "familial AD" (FAD)[18]. FAD is caused by mutations in the genes coding for the $\beta$-amyloid precursor protein (APP)[19] and the presenilin isoforms PS1 and PS2; A $\beta$ is produced from APP by the action of $\beta$ - and $\gamma$-secretases[20,21], and PS1/2 is the catalytic subunit of $\gamma$-secretase which produces A $\beta$ from APP together with $\beta$ secretase[22-26]. Thus, $A \beta$ is centrally implied both by biochemical hallmarks and genetic risk factors, leading to the dominance of the amyloid hypothesis in current drug development efforts[15,27,28].

Other biochemical hallmarks include molecular oxidative stress[29], impaired glucose utilization[30,31], and disturbed concentrations of metal ions, notably calcium[32-34], zinc[14,35,36], copper[37-41], and iron[42,43]. Each of these hallmarks have associated theories of pathogenesis assuming them to be causative, e.g. the tau[44-47], metal ion[48,49] and oxidative stress[50,51] hypotheses. Age is however the main risk factor of the disease[52] and should accordingly be central to any disease mechanism.

This review focuses on copper's increasingly recognized role in AD. Copper's importance to the central nervous system (CNS) is well-known and involves processes such as catecholamine synthesis, neurotransmission, adenosine triphosphate (ATP) synthesis, antioxidant defense, and myelin formation, which are briefly reviewed below and discussed elsewhere in detail[14,53-56]. Copper is crucial for CNS development and takes part in complex regulatory networks of proteins and pathways that maintain CNS homeostasis via the two copper-transporting P-type ATPases 
(copper-ATPases)[57,58]. In recent years, it has become increasingly clear that impaired copper control plays a role in $\mathrm{AD}$ development and progression, mainly via an increase in serum $\mathrm{Cu}$ not bound to ceruloplasmin (noncp-Cu)[55]. Increases in noncp-Cu pertains to a percentage of AD patients, a copper-related AD subtype, which we call 'CuAD', characterized by high noncp-Cu levels and showing peculiar clinical characteristics linked to a perturbed copper homeostasis. These changes in noncp-Cu can be merged with the physical chemistry of copper-binding proteins which is also strongly related to $\mathrm{AD}[49,56,59,60]$; the merging of these two fields to produce a united, consistent view of $\mathrm{CuAD}$ is the purpose of the present review paper.

\section{The amyloid hypothesis and its main problems}

The parallel between the plaque deposits in $\mathrm{AD}$ and the protein deposits in Creutzfeldt-Jakob disease inspired the hypothesis that the plaques in $\mathrm{AD}$ might be pathogenic[61]. When these plaques were found to consist primarily of aggregated $A \beta$ peptides, the basis for the amyloid hypothesis was established[62] and further supported by the three major genetic risk genes of FAD coding for PS1/PS2 and APP[15,27,63].

The amyloid hypothesis is a "gain-of-function" hypothesis, i.e. it proposes that $A \beta$ attains a toxic function in the brain that leads to disease[27,64]. Earlier it was commonly named the "amyloid cascade hypothesis", emphasizing a quantitative overload of toxic A $\beta$ leading to $\mathrm{AD}[15,63]$. The $\mathrm{A} \beta$ deposits in brains typically represent several years of total $\mathrm{A} \beta$ production[65]. Accordingly, drugs are pursued that prevent the formation of amyloids either by molecular interaction with $A \beta[66-69]$ or by modulating its formation[70-76].

PS1 mutations often produce lower amounts of all A $\beta$ isoforms than the wild type protein[20,77,78]. The 99-residue C-terminal fragment of APP (C99, produced by cleavage of APP by $\beta$-secretase (BACE1), is subsequently trimmed by $\gamma$-secretase in consecutive steps[79], resulting in $A \beta$ peptides that vary in length, most notably $A \beta_{40}$ and $A \beta_{42}[7,77]$, and the FAD mutations affect the precision of this cleavage[80,81] and tend to increase $A \beta_{42} / A \beta_{40}$ ratios[78,8285], which, rather than any absolute amount of $A \beta_{42}$ or $A \beta_{40}$, is the main consistent feature of FAD mutations[28,78,86]. The long amyloids harbor additional hydrophobic amino acids and are thus more prone to aggregation[87,88] and more toxic to cells as these two features tend to correlate[15,89,90]. Thus, the current version of the amyloid hypothesis rests not on the total $A \beta$ levels, but rather the local surplus of $A \beta_{42}$ leading to disease. The importance of the $A \beta_{42} / A \beta_{40}$ ratio is supported by its correlation with clinical age of onset of PSEN1 mutation carriers[91]. 
Many (estimated 20-40\%) cognitively normal older people possess enough senile plaques[92] to satisfy currently applied AD diagnostic criteria[93,94]. The measured signatures of neurodegeneration and cognitive decline do not correlate significantly with plaque load[4,64]. Neuron loss generally begins in specific parts of the brain (e.g. hippocampus) but APP and A $\beta$ is broadly distributed, implying other disease modifiers[95,96]. Rather than the plaques themselves, the intracellular soluble oligomers of $\mathrm{A} \beta$ are particularly toxic and are considered the pathogenic culprits in the current version of the amyloid hypothesis[97-102].

The toxicity of A $\beta$ oligomers depends substantially on their structure and size[103-105], and the specific pathogenic forms that allegedly causes AD remain unknown[90,106,107]. Also the mechanisms of action remain unknown although many have been suggested[108], including general seeding of protein misfolding[87,98,109], toxic redox reactions in their metal-bound forms[110-113], and $A \beta$ forming membrane channels that facilitate metal ion transport[114-118].

The physiological structures of $A \beta$ peptides are central for understanding their aggregation and natural functions[7,15,88,119]. The structural disorder of the peptide[120] makes measured toxicity very dependent on concentration, $\mathrm{pH}$, ionic strength, co-solvents, and the time scale of the experiment performed[89,121]. Whereas aggregated fibrillar $A \beta$ attains a regular $\beta$-sheet structure as seen in senile plaques, the free $A \beta$ monomer has a disordered coil-dominated structure with only a small amount of helix and $\beta$-strand[120,122-124] as reflected in structural models with PDB codes 1BA4[125], 1IYT[122], 2LFM[126], 1Z0Q[123], and 1AML[127] (Figure 1). However, in non polar co-solvents such as hexafluroisopropanol and close to membranes, the helix content of $A \beta$ monomers increases[127]. When $A \beta$ is in a membrane-like chemical environment, the Cterminal of $\mathrm{A} \beta$ forms an extended, potentially membrane-spanning helix, an observation that fits well with the widely documented membrane channel properties of $A \beta[115,117,128-130]$. The conformation, aggregation tendency, and potential function of $\mathrm{A} \beta$ monomers and oligomers depends on the coordination environment imposed by metal ions[131-133], as discussed further below. 

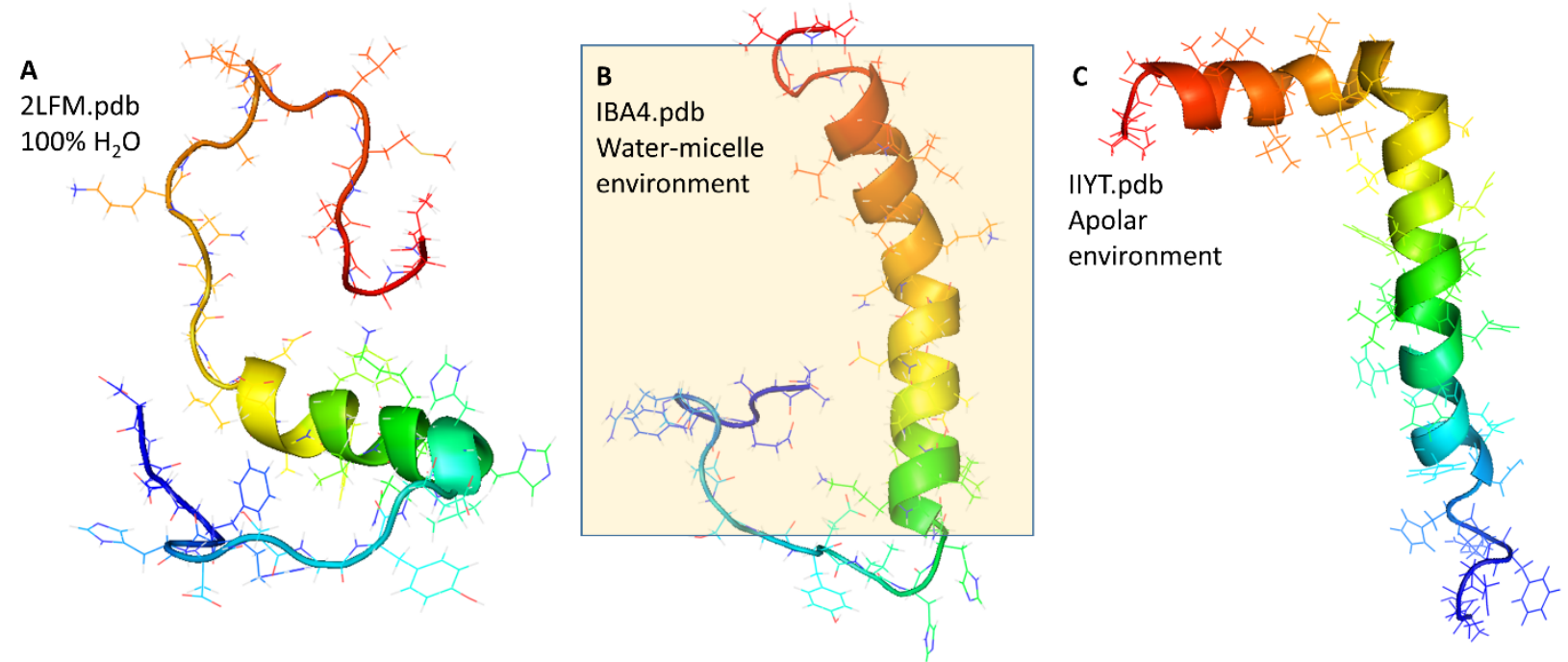

Figure 1. $A \beta$ structures derived from NMR experiments: A) $A \beta_{40}$ in water (PDB: $\left.2 L F M\right)[126]$. B) $\mathrm{A} \beta_{40}$ in a micelle membrane-mimicking environment (PDB: 1BA4)[125]. C) $A \beta_{42}$ in an apolar environment (20\% water, 80\% hexafluoroisopropanol) (PDB: 1IYT)[122]. N-terminals are shown in blue, and C-terminals in red.

\section{Brain copper homeostasis}

Copper is an essential trace metal that is required for the activity of many enzymes and proteins; its homeostasis has been reviewed many times before but is briefly summarized below $[14,134,135]$. The redox cycling between its $\mathrm{Cu}(\mathrm{II})$ and $\mathrm{Cu}(\mathrm{I})$ oxidation states is utilized by numerous enzymes[14,136]. Copper is mostly transported and buffered in its Cu(I) state intracellularly, as for example bound to metallothioneins (MT), copper-transporter 1 (Ctr1), and ATPases ATP7A/B, but is functionally important as $\mathrm{Cu}(\mathrm{II})[137,138]$. Vital functions involving copper directly in the catalytic active site include energy production via ATP synthesis in the mitochondria (cytochrome c oxidase, CCO), antioxidant defense (superoxide dismutase 1 and 3, SOD1 and SOD3), collagen maturation (lysyl oxidase), pigment synthesis (tyrosinase), and white and red blood cell production via hemoglobin synthesis and iron redox regulation (ceruloplasmin, haephestin)[14,137]. 

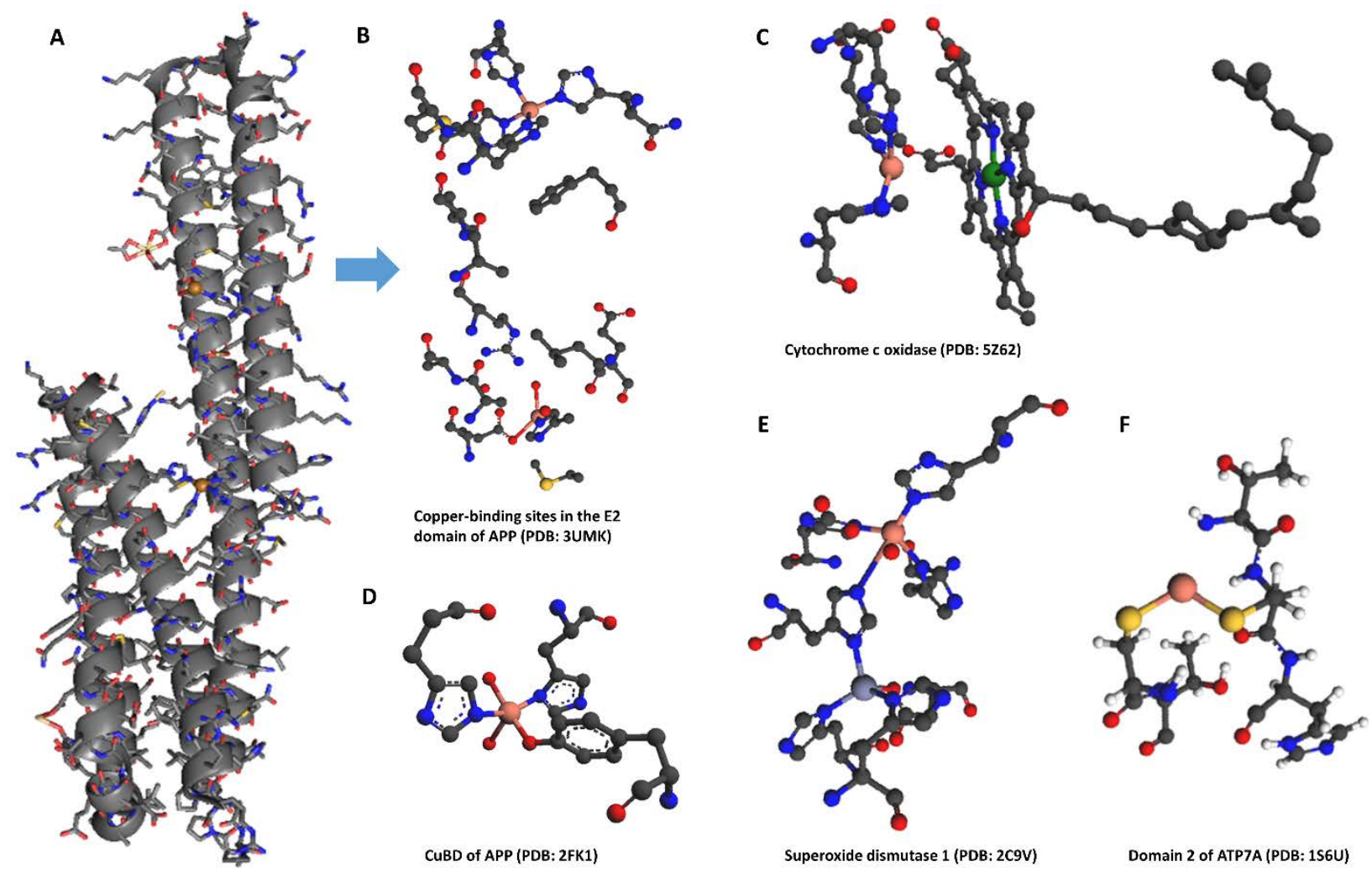

Figure 2. Established copper sites in some key proteins of the brain: (A) and (B) Copper-binding sites in the E2 domain of APP (PDB: 3UMK)[139]. (C) Copper (center, orange) in CCO (PDB: 5Z62)[140]. (D) Copper in the CuBD of APP (PDB: 2FK1)[141]. (E) Superoxide dismutase 1 (PDB: 2C9V)[142]. (F) Domain 2 of ATP7A (PDB: 1S6U)[143].

Examples of established copper sites in relevant proteins are shown in Figure 2A-2F. Most notably are the two copper sites in the extracellular E2 domain of APP (Figure 2A and 2B), one having a 4-histidine coordination sphere similar to that in SOD1 (Figure 2E), and the other E2 copper binding in a trigonal coordination geometry to one histidine, a carboxylate group of a glutamate residue, and a solvent water, with a potential coordinating methionine near-by[139]. Another copper site in APP is the so-called copper binding domain (CuBD)[144]; this copper binds two histidines and a tyrosine and two solvent molecules in a distorted trigonal bipyramidal geometry (Figure 2D)[141]. CCO, which is the terminal protein in the electron transport chain and thus required for energy production, contains both a $\mathrm{Cu}_{\mathrm{A}}$ and $\mathrm{Cu}_{\mathrm{B}}$ center. The $\mathrm{Cu}_{\mathrm{B}}$ is coordinated by three histidines and is located uniquely close to a heme iron to assist in 4-electronreduction of $\mathrm{O}_{2}$ (Figure 2C)[140]. Finally, the copper site in the ATPase is characterized by 
coordination to two cysteines in a distorted solvent-exposed coordination geometry; this structure is from solution NMR and thus less detailed (Figure 2F)[143].

In the brain, copper is also centrally involved in catecholamine synthesis via dopamine $\beta$ hydroxylase $(\mathrm{DBH})$, catecholamine degradation via monoamine oxidase (MAO), neuropeptide synthesis via peptidylglycine $\alpha$-amidating monooxygenase, glutamatergic synapse modulation, excitoxicity, and myelin formation[14,135]. Via its antagonistic relationship to zinc managed by the metallothioneins, copper also affects zinc levels and associated processes[38,145-148], which again affects calcium levels[149,150]. Via ceruloplasmin, copper modulates iron uptake and distribution by influencing the oxidative state of iron, since ceruloplasmin catalyzes the oxidation of Fe(II)to Fe(III), which is then loaded into transferrin[54,151].

As discussed in detail below, the chemical and pathological features of disease tend to converge in the synapse. A simplified view of the copper homeostasis at the synapse is displayed in Figure 3. The healthy normal situation is shown in Figure 3A. The integral membrane protein Ctr1 imports $\mathrm{Cu}(\mathrm{I})$, which is then loaded onto copper-dependent enzymes via chaperone proteins such as copper-chaperone for SOD1 (CCS) and MTs. The two copper-transporting ATPases are encoded by the genes ATP7A and ATP7B. Both ATPase7A and ATPase7B remove excess Cu from cells, control influx of copper into vesicles, whereas primarily ATPase7B delivers $\mathrm{Cu}$ for incorporation into $\mathrm{Cu}$-dependent enzymes. In the gastrointestinal tract, copper is pumped out by ATPase7A and then transported to the liver bound to albumin or $\alpha 2$ macroglobulin or amino acids via the portal vein. In the liver, ATPase B incorporates copper into ceruloplasmin. The majority of the plasma copper is strongly bound to ceruloplasmin (called here $\mathrm{cp}-\mathrm{Cu}$ ), whereas the remainder is loosely bound and is exchanged among albumin, $\alpha$-2-macroglobulin, amino oxidases, ferroxidase (II), SOD3, metallothioneins, and amino acids (called here noncp-Cu)[135,152,153].

In the central nervous system (CNS), astrocytes appear to play an important role in copper transport from the blood and cerebrospinal fluid (CSF) to the neurons[154,155], at the astrocyte foot (Figure 3A). At this site ATPase7A and ATPase7B control brain copper balance, starting from the early phases of development[156]. ATPase7A is expressed before birth, primarily in the hippocampus and cerebellum[157], then its levels decline. The protein is involved in synaptogenesis and axonal outgrowth and contributes to seizure resistance in hippocampal CA2 pyramidal cells[157]. ATPase7A is expressed in the basolateral membrane. While in the enterocyte it controls copper absorption into the body, in the endothelial cell of the blood brain barrier (BBB) it facilitates copper transport from the blood to the brain[158] and modulates synapses of 
glutamatergic neurons[159]. Inactivation of ATPase7A in Menkes disease disturbs the transport of $\mathrm{Cu}$ into the brain, which leads to neurodegeneration[155,160]. ATPase7B is expressed at the apical side of endothelial cells of the blood cerebrospinal fluid barrier and facilitates copper transport into the CSF, as well as copper sequestration into the choroid plexus[156]. ATPase7B is expressed mainly in the hippocampus, in the cerebellum and brain cortex, and acts as a mediator of the synthesis of the Cu-dependent enzymes mentioned above[160].

Several other proteins locate at neuronal membranes and bind copper, most notably APP, $\alpha$-synuclein ( $\alpha$-syn), and the prion protein (PrP), a glycoprotein located at synapse[161-163]. PrP is involved in copper uptake and efflux, and the metal facilitates PrPc internalization[164,165]. The interplay between copper and PrP appears to modulate glutamatergic transmission[166-169], and PrP also binds to $A \beta[170]$. Moreover, the binding of copper to the PrP increases its conversion to the infectious protease-resistant, $\beta$-sheet-rich form of the protein[171-173]. 


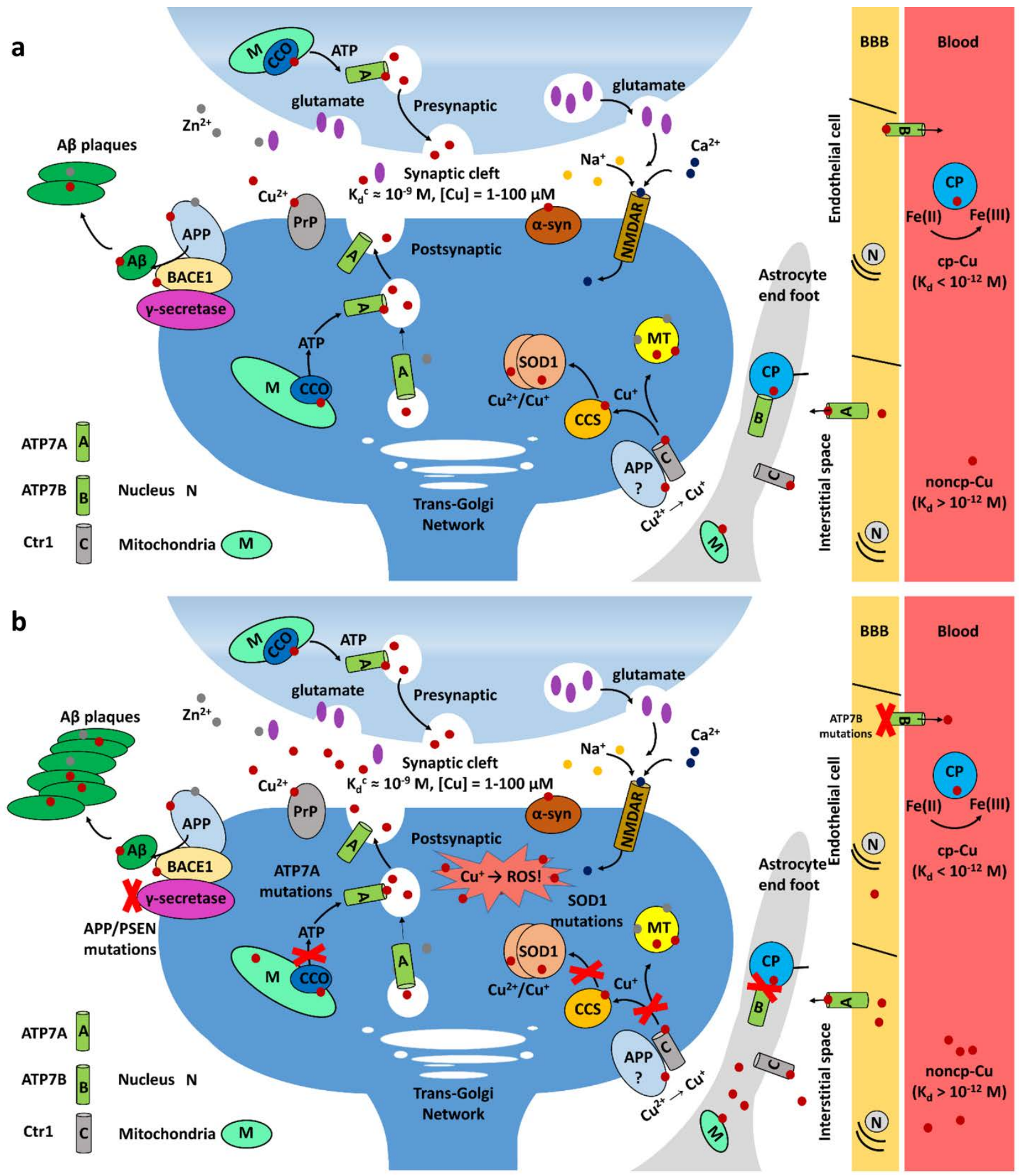

Figure 3. Simple overview of synaptic copper homeostasis. (A) Normal healthy brain. (B) CuAD brain. The main differences are shown as red copper and red crosses of probable impaired pathways. $\mathrm{CCO}=$ cytochrome c oxidase; SOD1 = Superoxide dismutase 1; $\mathrm{MT}=$ metallothionein; PrP = prion protein; CP = ceruloplasmin. In CuAD (B), genetic (APP, PSEN1, or ATP7B) or lifestyle-induced changes in copper transport and balance leads to increased labile $\mathrm{Cu}$, which disrupts ATP production (CCO), antioxidant defense (SOD1), and synaptic transmission. 
Much of the bioinorganic chemistry of neuronal copper occurs at the synaptic cleft, where $\mathrm{Cu}(\mathrm{II})$ is released from the postsynaptic terminal upon stimulation of the N-methyl-D-aspartate receptor (NMDAR) during glutamatergic neurotransmission (Figure 3A). $\mathrm{Cu}(\mathrm{II})$ is presumably in a 'free' form when it is released at the synaptic cleft and modulates glutamate neurotransmission by down-regulating the NMDAR activity[156]. Copper is also released from presynaptic vesicles during transmission[174] in a recycling process regulated by $\operatorname{PrP}[159,167,168,175-178]$, which is a natural synaptic $\mathrm{Cu}(\mathrm{II})$ binding protein[164,166,171,172]. Due to the small volume of the synaptic cleft, $\mathrm{Cu}(\mathrm{II})$ can transiently reach micromolar concentrations and peak levels can be up to 100 -fold higher[166].

While actual "free" exchangeable copper in the cytoplasm is virtually negligible at concentrations as low as $10^{-18} \mathrm{M}[14,179,180]$, the distinction between loosely bound and strongly bound copper is important. The strongly bound pool of copper is characterized by a tight coordination geometry of non-solvent ligands as seen in active sites of copper proteins[137]. In the plasma this fraction is mainly bound to ceruloplasmin (cp-Cu). The remaining plasma $\mathrm{Cu}$ (noncp-Cu) is loosely bound to albumin, $\alpha$-2-macroglobulin (transcuprein), and random peptides and amino acids and exchanged among them[136] and comes out from the liver; this type of copper crosses the $\mathrm{BBB}$, is chelatable and engages in toxic Fenton-like reactions that produce very reactive radicals such as hydroxyl, which can contribute to oxidative stress in the aging neuron[14,179,181,182].

\section{The critical $K_{d}$ of CuAD}

To differentiate the pathological and physiological Cu(II) pools, we use a threshold (or critical) dissociation constant $\mathrm{K}_{d}{ }^{c}$ : Since $\mathrm{K}_{d}=[\mathrm{Cu}][\mathrm{P}] /[\mathrm{CuP}]$ where $\mathrm{P}$ is the copper protein, $[\mathrm{Cu}]$ is the "free" copper concentration and $[\mathrm{CuP}]$ is the complex, a small $\mathrm{K}_{\mathrm{d}}$ corresponds to strong binding, whereas a large $\mathrm{K}_{\mathrm{d}}$ represents copper that is relatively exchangeable. The $\mathrm{Cu}(\mathrm{I})$ oxidation state binds generally much more strongly to proteins, reaching attomolar $\mathrm{K}_{\mathrm{d}}\left(\sim 10^{-18} \mathrm{M}\right.$ or lower) in high-affinity copper storage and transport proteins such as MTs and Ctr1[183]. Since the copper concentrations and the affinities of the copper proteins vary with redox state and location, the relevant $\mathrm{K}_{d}{ }^{c}$ is context-dependent, and we thus focus on the $\mathrm{K}_{d}{ }^{c}$ of $\mathrm{Cu}(\mathrm{II})$ at the synapse which reflects the discussed pathology. Evidence suggests that dyshomeostasis will spread from location to location, as described below for the impact of ATP7B variants on brain copper homeostasis[184- 
186]. The threshold $\mathrm{K}_{d}{ }^{\mathrm{c}}$ represents the affinity that separates, for the metal ion in the given location, the exchangeable solvent-accessible copper (all copper bound with $K_{d}>K_{d}{ }^{c}$ ) from the strongly bound, inaccessible copper (all copper bound with $\mathrm{K}_{d}<\mathrm{K}_{d}{ }^{\mathrm{c}}$ ). $\mathrm{K}_{\mathrm{d}}^{\mathrm{c}}$ is a constant of the redox state and location, whereas concentrations of the two pools of copper can vary. We define the copper dyshomeostasis as the situation where the ratio $[\mathrm{Cu}]\left(\mathrm{K}_{d}>\mathrm{K}_{d}{ }^{\mathrm{c}}\right) /[\mathrm{Cu}]\left(\mathrm{K}_{\mathrm{d}}<\mathrm{K}_{d}^{\mathrm{c}}\right)$ increases.

As mentioned, the concentrations of copper vary by orders of magnitude dependent on redox state and location, and the amount of exchangeable copper varies according to the $\mathrm{K}_{\mathrm{d}}$ of the local copper-proteins. In blood serum, the moderate-affinity copper-proteins albumin (10-15\% of copper[187], mostly exchangeable, $\mathrm{K}_{\mathrm{d}}<10^{-12} \mathrm{M}$ [188]) and $\alpha$-2-macroglobulin (5-15\% of copper, which exchanges with albumin, $\left.\mathrm{K}_{\mathrm{d}} \sim 10^{-12} \mathrm{M}[189]\right)$ and the high-affinity ceruloplasmin (40-70\% of copper, not exchangeable, $\mathrm{K}_{\mathrm{d}}=10^{-15} \mathrm{M}$ ) ensure very little exchangeable $\mathrm{Cu}(\mathrm{II})$. The threshold of exchangeable $\mathrm{Cu}(\mathrm{II})$ in this location is then arguably close to $\mathrm{K}_{\mathrm{d}}$ of albumin $\left(\mathrm{K}_{d}^{\mathrm{c}} \sim 10^{-12} \mathrm{M}\right)$.

However, at the pathologically relevant synaptic cleft we argue that $\mathrm{K}_{\mathrm{d}}{ }^{\mathrm{c}} \sim 10^{-9} \mathrm{M}$ : First, average $\left[\mathrm{Cu}^{2+}\right]$ at the synapses $(100-250 \mu \mathrm{M})[190]$ is $\sim 100-1000$-fold that of the CSF $(0.3-0.5$ $\mu \mathrm{M})[191]$ and the extracellular space $(\sim 1 \mu \mathrm{M})$ [192] and the exchangeable $\left[\mathrm{Cu}^{2+}\right]$ vary by 100 -fold during synaptic transmission, whereas it is kept small and constant in blood and CSF. Second, $\mathrm{K}_{\mathrm{d}}$ is surprisingly similar, typically $0.1-10 \mathrm{nM}$, for the disordered proteins suspected to be involved in synaptic $\mathrm{Cu}(\mathrm{II})$ transport and regulation, all being main culprits of neurodegenerative diseases, i.e. $A \beta, \operatorname{PrP}$, and $\alpha$-synuclein[193,194]. We argue that this is not a coincidence but reflects the $\mathrm{K}_{d}{ }^{\mathrm{c}}$ at the synapses. Third, the amount of copper in A $\beta$ plaques $(\sim 40 \mu \mathrm{M})[17]$ is similar to the average $\left[\mathrm{Cu}^{2+}\right]$ at the synapses $(100-250 \mu \mathrm{M})[190]$ indicating that the $\mathrm{K}_{\mathrm{d}}$ of $\mathrm{A} \beta$ is close to the threshold value for synaptic $\left[\mathrm{Cu}^{2+}\right]$. Fourth, micromolar $\mathrm{K}_{\mathrm{d}}$ values $\left(10^{-6} \mathrm{M}\right)$ in typical assays represent unspecific binding of labile metal ions such as Zn(II) with small binding free energy[14,193]. For $\mathrm{Cu}(\mathrm{II})$ at the same concentrations as $\mathrm{Zn}(\mathrm{II})$, a threshold $\mathrm{K}_{d}{ }^{\mathrm{c}}$ value 1000 -fold smaller $\left(\sim 10^{-9} \mathrm{M}\right)$ can be argued from $\mathrm{K}_{\mathrm{d}}$ of complex formation to typical N-donor and O-donor ligands, i.e. the IrvingWilliams series[195]. Fifth, we argue that the if ratio $[\mathrm{Cu}]\left(\mathrm{K}_{d}>\mathrm{K}_{d}{ }^{c}\right) /[\mathrm{Cu}]\left(\mathrm{K}_{d}<\mathrm{K}_{d}{ }^{c}\right)$ is increased in the blood as measured directly by noncp-Cu, this will also affect the ratio in other places. One example that we discuss further below is the analogy with failed copper incorporation into nascent ceruloplasmin upon defects of the ATP7B gene that cause Wilson's disease (WD), an autosomal recessive disease distinct from $\mathrm{AD}$ but with some biochemical features being similar to $\mathrm{CuAD}$ [54,160,196,197]. 
The $\mathrm{K}_{\mathrm{d}}$ of the involved copper proteins may change by mutation or post-translational modification such as oxidations of sulfur ligands, and this will accordingly change the proposed pathogenic ratio $[\mathrm{Cu}]\left(\mathrm{K}_{\mathrm{d}}>\mathrm{K}_{\mathrm{d}^{\mathrm{c}}}\right) /[\mathrm{Cu}]\left(\mathrm{K}_{\mathrm{d}}<\mathrm{K}_{\mathrm{d}}^{\mathrm{c}}\right)$. Most notably, $\mathrm{A} \beta$ exists in vivo in various modified forms, with emphasis on $\mathrm{N}$-terminal modified peptides of the type $A \beta_{4-x}$. Since these modifications affect the primary copper binding site, they also affect the $\mathrm{K}_{\mathrm{d}}$ of copper and can reach much higher affinity than the full peptide and thus be functionally important[198-203].

The definitions above have centered on the thermodynamic binding equilibria of $\mathrm{Cu}(\mathrm{II})$. $\mathrm{Cu}(\mathrm{II})$ binding may be under kinetic control if release of copper becomes rate-limiting for equilibrating the copper pools described above. The lability is the appropriate term if the ligandmetal interaction is kinetically controlled, measured as the life time of the ligand's association with the metal ion or the rate constant of ligand substitution[204]. The thermodynamic $\left(\mathrm{K}_{\mathrm{d}}\right)$ and kinetic (lifetime) definitions of pathological metal ions thus potentially differ, as indicated by some recent studies[205]. For high-affinity copper sites in proteins, kinetic control of copper pools may arise from barriers to release copper depending on the steric and electronic nature of the ligands. However, for the low-affinity synaptic proteins with $\mathrm{K}_{\mathrm{d}} \sim 10^{-10} \mathrm{M}-10^{-9} \mathrm{M}$, exchange is very fast. NMR relaxation recently showed that the pathogenic $\mathrm{A} 2 \mathrm{~V}$ mutation of $\mathrm{A} \beta$ exchanges $\mathrm{Cu}(\mathrm{II})$ much faster than the protective A2T and wild type $A \beta$, despite having similar $K_{d}$ values[206], suggesting a role of kinetics over thermodynamics in $\mathrm{Cu}(\mathrm{II})$ buffering. Rapid changes in $\left[\mathrm{Cu}^{2+}\right]$ at the synapses can produce other barriers than induce kinetic control despite fast metal-ligand dissociation, for example due to slow vesicle copper release or membrane transport at the synapses. Under such conditions, low affinity proteins such as the synaptic A $\beta, \alpha$-syn and PrP, will be much more adequate in restoring the copper pools, as copper is rapidly released from these sites on the timescale of synaptic transmission, supporting of a relatively high $\mathrm{K}_{\mathrm{d}}{ }^{\mathrm{c}}$ at the synapses.

\section{Clinical evidence: Copper dyshomeostasis in AD}

Metal ion imbalances are a consistent feature of $\mathrm{AD}[15,33,34,37,50,104,182]$. Several metaanalyses focusing on copper have been performed during the last 10 years merging data from more than 35 studies[207-211]; the most updated studies are shown in Table 1. The meta-analysis of copper in the brain shows that AD patients have lower levels of copper in their brains than healthy controls[185]. Meta-analyses monitoring the serum/plasma show increased copper in AD patients vs. controls[207,210-213]. This latter increase can be explained by the fact that the chelatable portion of copper (noncp-Cu) is increased in AD patients[209], in analogy with WD. A recent 
study comparing directly WD and AD patients showed that while the two diseases differ in terms of serum copper and ceruloplasmin levels, they share increased levels of noncp-Cu, indicative of a failure a copper control[197]. Expansion of the weakly bound $\mathrm{Cu}(\mathrm{II})$ in $\mathrm{AD}$ coincides with decreased levels of functional protein-bound $\mathrm{Cu}(\mathrm{II})$ in the brain[208], as has been found in autopsy studies[214]. Analysis of copper in cerebral cortex Brodmann areas 22 and 46 showed reduced copper in $\mathrm{AD}$ patients, associated with $20 \%$ increase of labile copper in the same Brodmann areas[214], as also confirmed in other studies [214,215]. The results for copper differ from those for many other metal ions, including Zn, implying their possible antagonistic relationship[216].

While there is some disagreement on the ceruloplasmin concentration levels in $\mathrm{AD}$ [217], data on ceruloplasmin activity, which importantly reflect fully constituted copper-bound protein, are univocal, and largely similar for all the reported studies[151,191,217-220]. Ceruloplasmin is a $132 \mathrm{kDa}$ multicopper oxidase that acts as an acute phase reactant scavenging oxygen-derived free radicals during inflammation states[54,187,221,222]. Ceruloplasmin is mainly synthesized in hepatocyte, where the ATPase 7B protein loads six copper atoms into apo-ceruloplasmin, generating an active holo-ceruloplasmin that is then transferred into blood circulation. It is also expressed in the kidney, mammary gland, placenta, and choroid plexus in the brain[187]. A ceruloplasmin isoform linked to the cell membrane by glycophosphatidyl inositol (GPI) is expressed endogenously by the CNS and is abundant in astrocytes in the vicinity of neurons[223]. A key process catalyzed by ceruloplasmin is the oxidation of $\mathrm{Fe}^{2+}$ to $\mathrm{Fe}^{3+}$, which reduces the availability of $\mathrm{Fe}^{2+}$, promoting instead iron transport to various organs by transferrin, which accepts only $\mathrm{Fe}^{3+}$ [224]. Ceruloplasmin also scavenges $\mathrm{H}_{2} \mathrm{O}_{2}$ thus preventing the production of dangerous oxygen species[225]. Holo-ceruloplasmin synthesis strictly depends on the amount of available copper in the liver[224] and on ATPase7B function[135,187]. Consequently, reduced copper availability or ATPase7B protein dysfunction increases the fraction of apo-ceruloplasmin, which has no ferroxidase capability and is rapidly degraded in plasma[135,187].

The specific activity of ceruloplasmin decreases in AD and higher values in serum were shown to reduce risk of the disease[217]. The holo-form of ceruloplasmin in CSF[191], along with ceruloplasmin activity in serum[217,220] are decreased in AD patients. Low-molecular-weight fragments of ceruloplasmin derived from apo-ceruloplasmin degradation have been detected in AD samples and are suggestive of a defective activity of the ATPase7B copper pump[226]. Same mechanisms can be applied to the brain, positing a defective loading of the metal into other copper proteins and enzyme. Supporting this notion, AD risk variants of ATP7B (rs732774 and 
rs1061472) have been found to cause abnormalities in the expression[227] and function of the ATPase7B[57]. As a whole this evidence suggests a disturbed activity of ATPase7B in loading the metal in copper proteins and enzymes in $\mathrm{AD}$ at liver but also at brain level.

Elevated levels of noncp-Cu in serum increase the risk of AD by approximately threefold[228,229] and contribute to a worse prognosis of the patients[230]. Some AD patients display increased levels of noncp-Cu correlating with altered patterns of electrical brain activity and brain atrophy, along with pathological levels of $\mathrm{A} \beta$ and tau-protein in the CSF, and more severe clinical outcome[55]. In one study, subjects with mild cognitive impairment (MCI) with elevated noncp$\mathrm{Cu}$ levels have a 3-fold increased probability of $\mathrm{AD}$ and faster conversion to $\mathrm{AD}$ [212]. Total copper and the ratio of copper to non-heme iron distinguished progressive MCI subjects from cognitively stable MCI subjects in a five-year follow-up study[37]. Other cross-sectional studies also demonstrated that noncp-Cu is higher in MCI than in healthy controls[219,231,232]. Large population studies suggest that copper imbalances occur at early stages of cognitive loss and AD development, and copper in the soil has been associated with increased mortality relating to AD (Table 1)[233].

Aside from $\mathrm{AD}$, other studies have related copper levels to cognitive performance: A high copper diet combined with high levels of trans- and saturated fatty acids associated with a 3-fold increase in loss of cognition (Table 1, [234]). High copper plasma concentrations have been associated with loss of cognitive performance in normal women (Table 1)[235], and a poorer working memory and attention in children[236] and adolescents[237] (Table 1). A recent study found that copper in hair correlates with low cognitive abilities, high regional gray matter volume over widespread areas of the brain, and larger indices of low density in brain tissues (Table 1)[238]. As a whole, these studies indicate that elevated noncp- $\mathrm{Cu}$ is associated with loss of cognitive performance. These indications are further supported by a study investigating a neuropsychological battery of 19 tests in a cohort of healthy elderly women[239].

Several studies indicate that noncp-Cu may serve as a biomarker for specific sub-group of $\mathrm{AD}$ [240]. AD patients stratified on the basis of a noncp-Cu cut-off[219] have different clinical[241,242] and genetic features that relate to the frequency of specific variants of the ATP7B gene[243]. This evidence supports the existence of a detectable metabolic subtype of AD associated to copper abnormalities $\mathrm{AD}[240]$, called here CuAD. The AD risk variants of $A T P 7 B$ (rs732774 and rs1061472) have been found to cause abnormalities in the expression[227] and function of ATPase 7B[57]. 
Many in vitro or in vivo studies have increased our knowledge about the likely causative mechanisms of copper dysregulation in $\mathrm{AD}[39,40,49]$. In vivo studies in animal models demonstrated that small amounts $(0.13 \mathrm{ppm})$ of $\mathrm{Cu}$ ingested through drinking water double plasma concentrations of noncp- $\mathrm{Cu}$, reduce $\mathrm{CSF} A \beta$ clearance via the $\mathrm{BBB}$ in wild type mice, and increase $\mathrm{A} \beta$ production in a mouse model of $\mathrm{AD}[244]$.

It is known from many studies that cholesterol can enhance $A \beta$ pathology in models of disease[245-248]. However, it was found that this tendency varied depending on the quality of water given to the animals, such that distilled water gave less pathology compared to tap water[249]. Strong evidence for a direct link between copper homeostasis and A $\beta$-related AD pathology came from the report that the reason is probably that trace amounts of $\mathrm{Cu}$ (II) (0.12 ppm) in water induce $A \beta$ accumulation and senile plaque-like structures in the hippocampus and temporal lobe of cholesterol-fed rabbits, with associated retardation of learning ability[250]. These findings were later confirmed in another study with controls against other metal ions, $\mathrm{Zn}$ and $\mathrm{Al}$, with no such effect[251]. These findings fit well with in vitro A $\beta$ aggregation seen in many studies being caused by trace metals in contaminated laboratory glassware[252].

A further indication of $\mathrm{Cu}$ dyshomeostasis in $\mathrm{AD}$ comes from the fact that MT expression changes in $\mathrm{AD}$ [253][254]. These small cysteine-rich proteins naturally bind and buffer the concentrations of copper and zinc[145,179,255]. The MTI and MTII isoforms are found in almost all organs, whereas MTIII is predominantly expressed in the CNS. MTIII possesses a unique neuronal growth inhibitory activity distinct from the MTI and MTII isoforms[145,256]. MTI/MTII biosynthesis is induced by a range of factors including glucocorticoids, cytokines, reactive oxygen species, and metal ions. Expression levels of the three isoforms differ in AD: MTI and MTII expression is increased in $\mathrm{AD}$ [256], stimulated probably by the presence of free radicals, metal ions, and cytokines[256-258], whereas MTIII levels are decreased, notably in the temporal cortex[259]. MTIII shows extracellular growth inhibitory activity that antagonizes the ability of AD brain extract to stimulate survival and neuritic sprouting[260]. By a not fully understood mechanism, the extracellular $\mathrm{Zn}_{7} \mathrm{MTIII}$ can protect neurons from toxic $\mathrm{A} \beta$, through an interaction of free $\mathrm{Cu}(\mathrm{II})$ and $\mathrm{Cu}(\mathrm{II})$ bound to $\mathrm{A} \beta[257,261]$. Accordingly, MTIII, but not MTI and MTII, have been reported to protect neuronal cells from $\mathrm{Cu}(\mathrm{II})$-amyloid toxicity[257,258]. Similar mechanisms have been observed also for $\alpha$-Syn and PrPSc proteins[258]: in vitro studies have demonstrated interaction of $\mathrm{Zn}_{7}$-MTIII and $\mathrm{Cu}(\mathrm{II})$-containing $\alpha$-Syn and PrPSc indicating that Zn 7 MTIII can be neuroprotective via copper transfer[257]. 


\section{Biochemical evidence: APP/A $\beta$ and copper transport}

As expected from their major presence, APP and the APP-like proteins APLP1 and APLP2, serve natural roles in neurons. APP-knockout reduces synaptic proliferation[262]. Knockout of both APP and APLP2 simultaneously is lethal and indicates an important role of APP/APLP2[263,264] with a partial ability of mutual compensation[265]. The proteins are particularly important for synaptic function and affects synaptic plasticity[266-269] and are essential for hippocampus function and spatial learning of mice[270].

$A \beta$ also seems to have normal functions in neurons[271-274]. Nanomolar concentrations tend to be neurotrophic, whereas micromolar concentrations as seen in cell assays are toxic[273,275]. The existence of a therapeutic window of $A \beta$ may explain observations of both loss- and gain of function in AD, depending on study conditions[273,276,277]. Inhibition or depletion of $A \beta_{40}$ by secretase inhibitors or antibodies is lethal to neurons[278]. $A \beta$ depletion has also been shown to impair neuronal activity in mice[271]. More specifically, A $\beta$ monomers seem to protect against copper- and iron-induced toxicity[272] and extracellular A $\beta$ increases vesicle release probability in hippocampal synapses[274]. Together with the findings for APP, these findings point to an important role of $\mathrm{APP} / \mathrm{A} \beta$ at the synapses.

Most of the proteins central to AD, including APP, $\mathrm{A} \beta, \alpha$-secretase, and the matrix metalloproteases that mainly degrade $A \beta$, have copper or zinc sites [14,279]. APP has multiple established metal binding sites[182,280-282] (Figure 2A, 2B, and 2D). The large extracellular part of APP contains the copper-binding domain (CuBD) [141,144,283]. A Zn(II) site is located within residues 181-200 of APP[284]. In addition, several other Cu(II) and Zn(II) sites are present in the E2 domain of APP-like proteins [139,285].

APP can reduce bound $\mathrm{Cu}(\mathrm{II})$ to $\mathrm{Cu}(\mathrm{I})$ [286], suggesting that APP may aid in transporting $\mathrm{Cu}(\mathrm{I})$ across the membrane similar to other proteins that enable $\mathrm{Ctr} 1 \mathrm{Cu}(\mathrm{I})$ transport, which requires a copper(II) reductase to bind $\mathrm{Cu}(\mathrm{I})$; in analogy to this function of APP, Ctr1 is cleaved from the membrane upon high concentration of copper to prevent uptake of copper[287]. Noteworthy, APP ablation in APP knock-out mouse model facilitates massive copper increases in the liver (80\%) and in the brain (40\%)[288]. This perturbation of copper efflux linked to APP ablation can be associated with an impairment of copper incorporation into copper proteins and the consequent increase of noncp-Cu that can reach the brain (up to 40\%) [288] Previous data 
indicate that $3 \%$ of serum noncp-Cu crosses the BBB in living AD patients[289], and consistent findings indicate a direct interaction of copper with A $\beta$ in the CNS[244,250,290].

Further evidencing a function of APP in copper transport, APP knockout in cultured neurons leads to reduced sensitivity to copper toxicity [291]. In addition, overexpression of APP can both lead to increased Cu(II) reduction and uptake in cells[292]; however, overexpression can also cause intracellular copper deficiency in mouse brains[293], indicating that APP, either directly or by its cleavage product $\mathrm{A} \beta$, also contributes to copper export. Other studies have shown that copper export caused by APP can be reduced by copper-chelators such as clioquinol[294]. The specific copper-binding domain of APP reduces toxicity from copper exposure[295], indicating a sensingtransport function to maintain intracellular copper concentrations at adequate levels. Inhibition of copper transporters increase $A \beta$ and decrease expression of $A \beta$-degrading zinc proteases [296].

Interestingly, this copper buffering function is regulated by calcium levels: APP cleavage is regulated by increases in calcium concentration[297]. Secreted APP fragments can protect the neurons against excitotoxicity and reduce intracellular calcium [298]. In contrast to its plausible role in reducing $\mathrm{Cu}(\mathrm{II})$, C-terminal APP instead increases intracellular calcium levels which causes glutamate-based excitotoxicity[299]. Thus the buffering effect of APP/A $\beta$ on copper and calcium seems to be antagonistic. Copper exposure to aged mice leads to $\mathrm{A} \beta$ accumulation and downregulation of low-density lipoprotein receptor-related protein 1 (LRP1) [244], which is a transporter of $A \beta$ [300] that also controls APP trafficking and processing[301,302]. However, dietary copper can also reduce A $\beta$ production[303], and copper deficiency directly changes APP processing and $A \beta$ secretion[304].

$\mathrm{A} \beta$ is a genuine metal-binding peptide with a typical $\mathrm{N}$-terminal metal-binding sequence including three histidines (His-6, His-13, and His-14 using A $\beta$ numbering[59,305]. Only two of them (His-6 and either His-13 or His-14) are thought to bind $\mathrm{Cu}(\mathrm{II})$ at any instance, and several ligand environments of the predominantly square-planar complex exists depending on $\mathrm{pH}[59,113,305-307]$. At low $\mathrm{pH}$ ( 6), only one histidine may bind $\mathrm{Cu}(\mathrm{II})$ probably due to protonation of the other[308]. Metal ions such as $\mathrm{Cu}(\mathrm{II})$ and $\mathrm{Zn}(\mathrm{II})$ mostly form 1:1 complexes with $A \beta[282,309-311]$. The $K_{d}$ for copper depends on the conditions of measurement but is approximately $10^{-10}-10^{-7} \mathrm{M}[56,113,138,203,206,280,306,312-314]$, about 2-3 orders of magnitude more strongly binding than $\mathrm{Zn}(\mathrm{II})$, in accordance with the Irving-Williams series of metal ion binding[14,195]. 
Metal binding generally changes the aggregation tendency of $A \beta$, in some cases favoring fibrillar aggregates and in other cases oligomers[14,49,310,315-319]. The metal-rich fibrils resemble the senile plaques characteristic of $\mathrm{AD}[123,206]$; however the $\mathrm{Cu}(\mathrm{II})$ bound states resemble early oligomers before aggregation, as estimated from thioflavin T assays[206,307]. The fibrils making up the senile plaques consist mainly of such extended sheets, packed with metal ions[17,123,320]. The coil-helix transition in low-dielectric environments (Figure 1A-1C) provides a structural rationale for its membrane channel function[116,128,321,322]. A $\beta$ is known to form metal ion channels in membranes[116,117,128,130,323-325]. Such interaction involves conformational transition from disordered to helix, as favored upon $\mathrm{Cu}(\mathrm{II})$ binding[326] and facilitated by membrane-like micelle environments[122]. In combination, these various facts provide the structural-chemical basis for the suggested function of $A \beta$ as a naturally disordered $\mathrm{Cu}(\mathrm{II})$ transport peptide[60], in agreement with the biochemical evidence of a copper-APP/A $\beta$ relationship cited above. Metal binding most likely increases the ability of the peptide to associate with membranes, since the hydrophilic charged N-terminal becomes helical and less charged upon metal binding (from -3 to -1 when binding a divalent metal ion)[327].

As mentioned, $A \beta$ is toxic and aggregation-prone at micromolar concentrations in typical assays[328,329]. However, this concentration corresponds to typically one year of total production and is 1000 -fold higher than the normal sub-nanomolar concentrations $\left(10^{-10} \mathrm{M}\right)$ of $\mathrm{A} \beta[330,331]$. Thus, the threshold concentration range separating beneficial and harmful $\mathrm{A} \beta$ is $10^{-7}-10^{-9} \mathrm{M}$. Considering that $\mathrm{A} \beta$ typically forms $1: 1$ complexes with a $\mathrm{K}_{\mathrm{d}}$ of $\mathrm{Cu}(\mathrm{II})$ of $10^{-10}-10^{-7} \mathrm{M}$, 2-3 orders of magnitude more strongly than $\mathrm{Zn}(\mathrm{II})$, one can expect synaptic $\mathrm{A} \beta$ to buffer the $\mathrm{Cu} / \mathrm{Zn}$ ratio in the synapses at 1/1000-1/100 approximately; this ratio is arguably important upon $\mathrm{Zn}$ and $\mathrm{Cu}$ release during glutamatergic neurotransmission.

$\beta$-secretase (BACE1) initiates production of A $\beta$ by cleaving its $N$-terminal from APP[332]. The transmembrane region of BACE1 contains a highly conserved copper binding site[333-335]. Overexpression of BACE leads to reduced SOD1 activity due to loss of intracellular protein-bound copper[334,335]. Similarly, copper exposure leads to increased APP expression and A $\beta$ formation by action of a copper sensing protein (CUTA) that interacts with the $\beta$-cleavage site of APP[336]. Recent work suggests that BACE1 functions via trimer formation upon cystine bridge formation to compartmentalize copper within the cell[337].

Further support for an in vivo relationship between APP/A $\beta$ and copper comes from chelation studies. A variety of metal chelators, typically large complex phenolic $\mathrm{N}$ - and O-donor 
systems such as clioquinol[338], coumarin[339] and benzylideneindanone[340] derivatives, and myricetin[341] reduce amyloid plaque formation[342], down-regulate APP expression and lower A $\beta$ production with associated loss of intracellular loosely bound copper [343]. Strong metal chelators such as EDTA (estimated $\mathrm{K}_{\mathrm{d}} \sim 10^{-19} \mathrm{M}$ from $\log \mathrm{K}_{\mathrm{f}}=18.8$ ) reduce $\gamma$-secretase activity and thereby, production of $A \beta[344]$. Metal chelators reduce $A \beta$ levels in cultured cells[345,346] and in Drosophila expressing human $A \beta[347]$, and at the same time such chelators can improve the cognition of mice[348].

\section{Molecular mechanisms of copper toxicity in CuAD}

The mechanisms relating copper translocation in compartments prone to the disease are both loss of function (loss of bound copper in enzymes involved in anti-oxidant stress and energy production) and gain of function (induced protein aggregation, toxic redox activity of $\mathrm{Cu}-$ complexes), and both processes eventually contribute to neuronal death[60,277]. Even though the detailed mechanisms of these complex processes are still elusive, the many data reviewed in this work suggest that they act in concert in some AD patients.

Recent work shows that noncp-Cu has 95\% specificity in detecting AD patients affected by CuAD[219], characterized by higher frequency of rs1061472 and rs732774 of the ATP7B gene, associated with susceptibility to AD due to copper exposure[243]. These gene variants are functional single nucleotide polymorphisms that modify expression and properties of ATPase7B[227]. ATPase7B loads copper onto nascent ceruloplasmin in the hepatocyte and onto the glycophosphatidyl inositol (GPI)-ceruloplasmin expressed in the astrocyte, and slight defects in this process associated with ATP7B rs1061472 and rs732774 may explain the increased release of noncp-Cu in the blood[209] and decreases in ceruloplasmin expression and activity in both blood and CSF[135,187,191,217] and probably alterations in the expression of additional copper proteins of the brain[156].

Focusing first on the gain of toxic functions, when the pool of exchangeable copper increases in blood (as noncp-Cu) and in the brain, it may change the conformations of many intrinsically disordered proteins, as widely documented by $\mathrm{Cu}(\mathrm{II})$ binding leading to oligomer seeding and aggregation of $\mathrm{A} \beta[102,133,206,252,307,319,349,350]$. Cu(II) may also engage in Fenton-like chemistry after reduction to $\mathrm{Cu}(\mathrm{I})$ in the reducing cell[14,351,352]. Overload of $\mathrm{Cu}(\mathrm{II})-\mathrm{A} \beta$ molecules is also probable, particularly at the synapses where both are available at much higher than normal concentrations[53,159,274,353]. These complexes by themselves also have 
both redox-toxic and potentially beneficial effects[181,199,206,314,354] that are so far not well understood in context, and separating the negative and positive effects of $\mathrm{Cu}$ (II)-A $\beta$ (and other metal-A $\beta$ complexes) is of major importance[60,277]. Efforts to modulate the aggregation tendency and redox toxicity of both amyloids alone and $\mathrm{Cu}(\mathrm{II})-\mathrm{A} \beta$ complexes are accordingly of major current interest[74,75,355-359].

One underlying systemic variable of neurons that could potentially unify the risk factors of metal ion and protein dyshomeostasis is thus energy. The brain uses half of its energy for glutamatergic signaling and perhaps $30 \%$ of the remaining energy for protein synthesis and degradation. Cognition and memory are defined by energy requirements unique to the brain and are much more expensive in humans than rodents, ranging from $34 \%$ in rodents to $74 \%$ in humans[360,361]. The energy production decreases and the energy cost of maintenance grow monotonously with aging, providing a direct rationale for the age trigger of disease[362-364], with energetic abnormalities and energy efficiency (diabetes risk factors) being hallmarks of AD[365367].

The catalytic reduction of molecular oxygen $\left(\mathrm{O}_{2}\right)$ to water $\left(\mathrm{H}_{2} \mathrm{O}\right)$ by CCO generates the electrical gradient used by the mitochondria to create ATP, and mitochondrial dysfunction and associated quality control, which occurs upon impaired energy production, is a hallmark of AD and other neurodegenerative diseases[363,368-370]. If copper is lost from the bound functional pools, mainly from CCO, this energy production will be impaired, such that energy surplus for cognition may ultimately be affected. At the same time, noncp-Cu can increase stress of misfolded proteins that in turn can increase the cost of turnover[371,372]. A $\beta$ 's role in this vicious circle may possibly be to restrain and buffer the increased levels of oxidative stress and the disruption of the ionic gradients due to copper dysfunction (Figure 3B).

\section{Analogies to other Cu-related diseases}

WD is the paradigmatic disease of noncp-Cu overload in tissues and organs caused by failure of copper incorporation into ceruloplasmin in the hepatocyte[196,240]. Upon ATP7B mutations noncp- $\mathrm{Cu}$ increases in the liver, brain, and the cornea of the eye (Kayser-Fleischer rings), producing oxidative stress and tissue damage[135,373]. As a consequence WD has a broad spectrum of symptom presentation. About one third of cases present with liver disease, another third with neurological manifestations, and the last third involves psychiatric and behavioral abnormalities[196,374-380]. In WD brains, the labile component of Cu is increased and deposition 
occurs particularly in the basal ganglia, associated with gliosis, neuronal loss[381] and features that resemble Parkinson‘s disease[382].

Mass screening in Korea suggests that WD may be much more common than previously estimated and reach 1:3000 to 1:1500 cases[377,383]. In line with this, a recent study reported an unexpected rate of about 1 in 40, higher than the 1:90 previously reported, of $A T P 7 B$ heterozygote mutation carriers in UK, yielding a prevalence of 1 per 7000 inhabitants[377,384]. The large discrepancy between the estimated genetic prevalence of WD based on ATP7B mutation frequency and the number of clinically diagnosed WD patients, which is significantly lower, motivates the hypothesis that $A T P 7 B$ mutations may increase the likelihood of other neurological or mental disorders, e.g. AD. In line with this hypothesis, some $A T P 7 B$ mutations have been identified in AD patients[385]. Multiple ATP7B variants modify copper homeostasis and the risk of the disease, and at least in a percentage of patients, specific loci of the ATP7B (primarily K952 and R832) contribute to the global susceptibility of developing AD (CuAD) [386]. ATP7B Genetics appears to drive a large part of the association between copper abnormalities and brain development and function. The BREATHE project highlights an interaction between specific ATP7B variants (including $A T P 7 B$ R832) and alterations of basal ganglia structure and its function in the brain [387] (Table 1). Multiple ATP7B gene variants apparently interplay with diet or life style to modify susceptibility and disease phenotype, and could thus provide correlations to nutrition during aging, when the copper requirements are reduced relative to other phases of life[388].

\section{Combining the facts into a simple model of AD due to copper dyshomeostasis}

The many studies of the role of copper at the synapse suggest that APP can play a role in reducing $\mathrm{Cu}(\mathrm{II})$ to $\mathrm{Cu}(\mathrm{I})$ to enable $\mathrm{Ctr} 1$ function, and that ATP7A/B can facilitate copper translocation into vesicles, which can then be released at the synaptic cleft as part of the glutamatergic transmission that occurs also in the hippocampus at the pyramidal CA1 synapse[159,167,174] (Figure 3A). In this model PrP and APP can serve as buffer proteins that control [Cu(II)] within the synaptic space, where it can reach micromolar concentrations and is subject to major variations[166,389]. The threshold binding strength of these $\mathrm{Cu}(\mathrm{II})$ ions at the synapse is of the order of $10^{-9} \mathrm{M}$, which is, incidentally, also the typical neuronal concentration of $\mathrm{A} \beta$, which also tends to localize at synapses[353,390]. A $\beta$ binds copper preferably with 1:1 stoichiometry[199,203,305,391] and interacts with the membranes to form calcium channels[115,116,128,324]. 
The evidence summarized above strongly suggest that copper dyshomeostasis can interfere with this basic synaptic process in at least a subset of AD patients. We define this dyshomeostasis as a change from strongly bound synaptic copper pools $\left(\mathrm{K}_{\mathrm{d}}<10^{-9} \mathrm{M}\right)$ to loosely bound pools $\left(\mathrm{K}_{\mathrm{d}}\right.$ $>10^{-9} \mathrm{M}$ ) over time, with a correlated excess noncp-Cu in the blood. The resulting change in the proposed pathogenic ratio $[\mathrm{Cu}]\left(\mathrm{K}_{d}>\mathrm{K}_{\mathrm{d}} \mathrm{c}\right) /[\mathrm{Cu}]\left(\mathrm{K}_{\mathrm{d}}<\mathrm{K}_{\mathrm{d}}{ }^{\mathrm{c}}\right)$ would make it more difficult for the copper buffer proteins to restore copper pools. A concomitant loss of functional bound copper in copper proteins will impair SOD1 activity and ATP synthesis by CCO, causing energy depletion and oxidative stress (Figure 3B). The disruption of copper homeostasis at the synapse can affect the synaptic strength: Application of physiologically relevant concentrations of $1 \mu \mathrm{M} \mathrm{CuCl}_{2}$ in rat hippocampal slices inhibited long-term potentiation, which is one of the basic processes of learning and memory[392]. Similar pathology is observed in rats fed with a high copper diet[393] or injected with copper[394].

A previous model of copper involvement in $\mathrm{AD}[240]$ held that the neurovascular unit has a primary role in regulating the transport of copper from the blood to the interstitial space in the brain. The concentration of $\mathrm{Cu}$ in the interstitial space is primarily controlled by the astrocytes and the other cells of the neurovascular unit[155]. ATPase7B and ATPase7A and Ctr1 have primary control over Cu levels (Figure 3A). Specific variants in the ATP7B gene (e.g. rs1061472 and rs732774, but additional variants may exist) affect the expression and function of the ATPase7B pump[57,136,227] (Figure 3B). $\quad$ Overtime, ATP7B dysfunction may increase noncp-Cu in serum plasma and reduce the copper loaded into copper proteins (including transporters) and enzymes, as exemplified by reduced ceruloplasmin specific activity[135,187,191,217]; in the brain these processes can correspond to copper depletion and probably a general loss of function of copper proteins including ATPase7B, CCO, SOD1, DBH, and MAO[156]. In particular, DBH catalyzes the formation of noradrenaline from dopamine. Midbrain catecholamine diffuse neurotransmitter systems have broad effects that affect the entire cerebral cortex. Apart from the disturbed equilibrium of the neurotransmitters (dopamine, noradrenaline, serotonin) which almost certainly would affect brain function, increased levels of dopamine may contribute to oxidative stress via autoxidation and MAO activity, generating $\mathrm{H}_{2} \mathrm{O}_{2}$ that can directly react with noncp-Cu in Fenton-type reactions producing the extremely reactive hydroxyl radical $(\mathrm{OH} \bullet)[14,395]$.

The many data indicating that the natural APP/A $\beta$ function relates to copper (and possibly zinc) transport at the synapses put the amyloid hypothesis in close and logic relationship to the model described above. Since the APP/A $\beta$ system aids copper transport at the synapses, the 
disruption of $A \beta$ levels by PSEN or APP mutations would contribute to a disturbance of the copper homeostasis, as indicated in Figure 3B[60,277,396]. In this model, APP and PSEN mutations, the main genetic risk factors of familial early-onset $\mathrm{AD}$, cause disease by a partial loss of function that manifests at high age when the overall copper homeostasis is already stressed. We also note that mutations in SOD1 cause Amyotrophic lateral sclerosis[397-399], a severe motor neuron disease which we speculate, because of its many clinical similarities to $\mathrm{AD}$, share some of the pathways shown in Figure 3B, notably those relating to copper-constituted functional SOD1.

\section{Conclusions}

From the evidence collected it is clear that copper dysfunction pertains to a percentage of AD patients, a condition we call here CuAD. This copper dysfunction can explain a fraction of the global susceptibility for AD. In addition to the pathological and clinical evidence, there is also substantial biochemical support for a strong link between copper status and APP/A $\beta$, with current evidence pointing toward a function in copper transport across neuronal membranes, either directly or indirectly, as a support of $\mathrm{Ctr} 1$. Thus the main hallmark of $\mathrm{AD}, \mathrm{A} \beta$, is a proficient copper binding peptide with a very broad range of data now documenting how copper binds and modifies $A \beta$ structure, aggregation, and toxicity.

For the subset of $\mathrm{AD}$ associated to copper dysfunction, causes relate to four processes that can be summarized as follows: i) increased frequency of specific ATP7B variants, ii) increased levels of noncp-Cu, and iii) decreased specific activity of ceruloplasmin; iv) decreased proteinbound copper into the brain, such as ceruloplasmin, ATPase7B, MT, CCO, SOD1, and DBH[400403]. These processes can influence each other but standing alone they can still increase the risk of the disease. They can trigger a cascade of processes that involve neurotransmitter alteration, oxidative stress, and disruption of energy production, eventually leading to cell death. Large population studies and meta-analyses support the proposed pathways shown in Figure 3.

We suggest that the transition from bound functional copper to "free" chelatable noncp-Cu is defined by a location-dependent threshold binding constant for pathogenicity which is approximately $\mathrm{K}_{\mathrm{d}}^{\mathrm{c}} \sim 10^{-12} \mathrm{M}$ in blood and $\mathrm{K}_{\mathrm{d}}^{\mathrm{c}} \sim 10^{-9} \mathrm{M}$ in synapses, where stronger binding represents innocent functional copper and weaker binding represents, at least to some extent, the redox-active gain-of toxic function. A large reduction potential of the $\mathrm{Cu}(\mathrm{II})$ concomitant with access to reductants such as ascorbate produces the $\mathrm{Cu}(\mathrm{I})$ state that may undergo Fenton-like 
reactions[404]; it is quite interesting that $\mathrm{Cu}(\mathrm{II})-\mathrm{A} \beta$, which is also a weakly bound copper-system, can do the same[202,405]. At oxidative conditions hydroxyl radicals are not formed to a great extent[352] but in the reducing environment of neurons they are likely to do so, as well as reacting with sulfur groups of proteins[404]. This threshold represents the shift form specific (controlled and contained) to nonspecific binding in physical chemical binding assays[14,193]. The $K_{d}$ of $A \beta$ for copper is $10^{-9} \mathrm{M}$ which is strong enough to bind and sequester the "free" copper but weak enough to release it after transport. Copper binding to $\mathrm{A} \beta$ changes its conformation and increases its hydrophobicity, probably thus enabling interaction with membranes. Mutations in PSEN1 and PSEN2 that cause FAD change the production of $A \beta$ peptides which may affect the specific transport capacity of copper-A $\beta$ across the neuronal membrane[60].

Finally, we would like to emphasize that Professor Brewer, based on epidemiological and demographic data that are completely orthogonal to the chemical, genetic and clinical data presented here, has put forward a theory that a subset of sporadic AD can be caused by increased copper exposure. He reaches this suggestion based on data from developed and industrialized countries with and without copper piping in a historical context and from toxicological studies of the $A \beta$ pathology induced by normal copper exposure in drinking water[406-408]. Given that the biochemical mechanisms would be similar to those described here and thus strongly documented, we suggest that this possible contribution to sporadic AD is explored further.

\section{Conflicts of interest}

KPK declares that he has no commercial or noncommercial conflicts of interest relating to this work. RS is Chief Scientific Officer of IGEA Pharma N.V. and has some shares in Canox4drug and IGEA Pharma N.V., but does not receive monetary compensation. 
Table 1. List of the most updated meta-analyses of copper in Alzheimer's disease, in developmental disorders, and epidemiological studies of copper in cognition. ${ }^{\mathrm{a}}$

\begin{tabular}{|c|c|c|c|c|c|c|c|}
\hline \multicolumn{8}{|c|}{ Most updated meta-analyses copper in Alzheimer's disease } \\
\hline $\begin{array}{l}\text { Reference } \\
\text { (Author, year) }\end{array}$ & \begin{tabular}{|l|l} 
Cu & Tiomarker \\
sa \\
so
\end{tabular} & $\begin{array}{l}\text { Tissues } \\
\text { sample } \\
\text { sources }\end{array}$ & $\begin{array}{l}\text { Studies } \\
\text { analyzed }\end{array}$ & $\begin{array}{l}\text { Number } \\
\text { of AD Cases }\end{array}$ & $\begin{array}{l}\text { Number of } \\
\text { controls }\end{array}$ & Trend & p value \\
\hline Li et al. 2017[211] & $\mathrm{Cu}$ & serum & 35 & 2128 & 2889 & increase & $<0.0001$ \\
\hline $\begin{array}{l}\text { Squitti et al. } \\
\text { 2014[209] }\end{array}$ & nCp-Cu & serum/plasma & 10 & 599 & 867 & increase & $<0.001$ \\
\hline $\begin{array}{l}\text { Bucossi et al. } \\
2011[207]\end{array}$ & $\mathrm{Cu}$ & serum/CSF & 5 & 116 & 129 & $\begin{array}{l}\text { no diff in } \\
\text { CSF, } \\
\text { increase in } \\
\text { serum }\end{array}$ & \\
\hline $\begin{array}{l}\text { Schrag et al. } \\
\text { 2011[208] }\end{array}$ & $\mathrm{Cu}$ & brain & 7 & 115 & 123 & decrease & $=0.0003$ \\
\hline \multicolumn{8}{|c|}{ Meta-analyses of copper in neurodevelopmental disorders } \\
\hline $\begin{array}{l}\text { Reference } \\
\text { (Author, year) }\end{array}$ & \begin{tabular}{|l|l} 
Condition & $\mathbf{T}$ \\
& sa \\
& so
\end{tabular} & $\begin{array}{l}\text { Tissues } \\
\text { sample } \\
\text { sources }\end{array}$ & $\begin{array}{l}\text { Studies } \\
\text { analyzed }\end{array}$ & $\begin{array}{l}\text { Number of } \\
\text { Cases } \\
\text { analyzed }\end{array}$ & $\begin{array}{l}\text { Number of } \\
\text { controls }\end{array}$ & Results & \\
\hline $\begin{array}{l}\text { Saghazadeh et al. } \\
2018 \text { [409] }\end{array}$ & $\begin{array}{l}\text { febrile } \\
\text { seizures }\end{array}$ & Serum/plasma & 4 & 99 & 92 & Cu increases & in patients \\
\hline $\begin{array}{l}\text { Saghazadeh et al. } \\
2015 \text { [409] }\end{array}$ & epilepsy & Serum/plasma & 10 & 934 & 899 & No changes il & $\mathrm{nCu}$ \\
\hline \multicolumn{8}{|c|}{ Epidemiological studies of copper and cognition } \\
\hline $\begin{array}{l}\text { Reference } \\
\text { (Author, year) }\end{array}$ & $\begin{array}{l}\text { Type of } \\
\text { analysis }\end{array}$ & $\begin{array}{l}\text { Number of } \\
\text { Cases } \\
\text { analyzed }\end{array}$ & Results & & & & p value \\
\hline $\begin{array}{l}\text { Morris et al. } 2006 \\
{[234]}\end{array}$ & $\begin{array}{l}\text { Longitudinal, } \\
9 \text { years follow } \\
\text { up }\end{array}$ & \begin{tabular}{l|l}
, & $\begin{array}{l}3718 \\
\text { w- CHAP } \\
\text { study) }\end{array}$
\end{tabular} & $\begin{array}{l}\text { Among pe } \\
\text { trans fats, } \\
\text { faster rate } \\
\text { fifth of cu } \\
\text { fats lost co }\end{array}$ & $\begin{array}{l}\text { sons whose die } \\
\text { igher copper ir } \\
\text { f cognitive dec } \\
\text { ntake combine } \\
\text { gnition three tir }\end{array}$ & $\begin{array}{l}\text { s were high ir } \\
\text { ake was asso } \\
\text { ine (participa } \\
\text { with a diet hi } \\
\text { es faster than }\end{array}$ & $\begin{array}{l}\text { turated and } \\
\text { ted with a } \\
\text { in the highest } \\
\text { in saturated } \\
\text { pected). }\end{array}$ & $<0.01$ \\
\hline
\end{tabular}




\begin{tabular}{|c|c|c|c|c|}
\hline $\begin{array}{l}\text { Lam et al. } 2008 \\
\text { [235] }\end{array}$ & $\begin{array}{l}\text { Cross- } \\
\text { sectional, and } \\
\text { cores on } 11 \text { of } \\
12 \text { cognitive } \\
\text { function tests } \\
\text { Plasma } \\
\text { analysis }\end{array}$ & $\begin{array}{l}1551 \\
\text { (Rancho } \\
\text { Bernardo } \\
\text { Study) }\end{array}$ & $\begin{array}{l}\text { In women copper concentrations had inverse linear } \\
\text { associations with Buschke total, long and short-term } \\
\text { recall and Blessed scores (cognitive test). }\end{array}$ & $<0.001$ \\
\hline $\begin{array}{l}\text { Shen et al. } 2014 \\
\text { [233] }\end{array}$ & $\begin{array}{l}\text { Copper } \\
\text { concentration } \\
\text { in soil in } \\
\text { relation to } \\
\text { annual } \\
\text { mortality of } \\
\text { AD }\end{array}$ & $\begin{array}{l}\text { Chinese } \\
\text { general } \\
\text { population, } \\
\text { from 1991- } \\
2000 \text {, in } 26 \\
\text { provinces, } \\
3 \text { districts }\end{array}$ & $\begin{array}{l}\text { relative risk of mortality in the regions with the highest } \\
\text { copper concentrations (60-80 mg/kg) was high [OR: } 2.63 \\
(95 \% \text { CI: } 2.626-2.642)]\end{array}$ & $<0.001$ \\
\hline $\begin{array}{l}\text { Zhou et al. } 2016 \\
\text { [410] }\end{array}$ & & $\begin{array}{l}826 \\
\text { children }\end{array}$ & $\begin{array}{l}\text { significant association between high copper levels and } \\
\text { poorer working memory in boys (unstandardized } \\
\text { regression coefficient (b) = -0.099, robust standard error } \\
\text { (s.e.) }=0.009, \mathrm{t}=-10.99, \mathrm{p}=0.008,95 \% \mathrm{CI}(-0.138 \text {, - } \\
0.060) \text {. }\end{array}$ & \\
\hline $\begin{array}{l}\text { Kicinski et al. } \\
2015 \text { [237] }\end{array}$ & & & $\begin{array}{l}\text { A two-fold increase in blood } \mathrm{Cu} \text { was associated with a } \\
0.37 \text { standard deviation decrease in sustained attention } \\
(95 \% \text { CI: }-0.67 \text { to }-0.07, \mathrm{p}=0.02 \text { ) and } 0.39 \text { standard } \\
\text { deviation decrease in short-term memory ( } 95 \% \mathrm{CI}:-0.70 \\
\text { to }-0.07, \mathrm{p}=0.02) \text {. }\end{array}$ & \\
\hline $\begin{array}{l}\text { Pujol et al. } 2016 \\
{[387]}\end{array}$ & & $\begin{array}{l}2836 \\
\text { children } \\
\text { aged from } \\
8 \text { to } 12 \\
\text { years. }\end{array}$ & $\begin{array}{l}\text { The results establish an association between } \\
\text { environmental copper exposure in children and } \\
\text { alterations of basal ganglia structure and function. }\end{array}$ & $\mathrm{P}<0.001$ \\
\hline $\begin{array}{l}\text { Takeuchi et al. } \\
2019 \text { [238] }\end{array}$ & $\begin{array}{l}\text { gray matter } \\
\text { volume } \\
\text { (rGMV), mean } \\
\text { diffusivity } \\
\text { (MD), and } \\
\text { cognitive } \\
\text { performance }\end{array}$ & $\begin{array}{l}924 \\
\text { healthy } \\
\text { young } \\
\text { adults }\end{array}$ & $\begin{array}{l}\text { Cu in hair associates with aberrant cognitive functions, } \\
\text { greater rGMV in extensive areas, greater MD (which are } \\
\text { indicative of low density in brain tissues) in subcortical } \\
\text { structures in the healthy young adults }\end{array}$ & $\begin{array}{l}\mathrm{P}<0.0001 \\
\text { for } \\
\text { rGMVs }\end{array}$ \\
\hline
\end{tabular}




\begin{tabular}{|l|l|l|l|l|}
\hline Alemany et al. & & $\left.\begin{array}{l}1,645 \\
\text { scholar }\end{array} 411\right]$ & ATP7B rs1061472 (P for interaction 0.016) and ATP7B- \\
children & rs1801243 (P for interaction 0.003) polymorphisms & modified the association between indoor copper exposure \\
from the & and inattentiveness. & \\
BREATHE & & & \\
& project & & \\
\hline
\end{tabular}

a Risk is reported as OR=Odds ratio; $\mathrm{CI}=$ Confidence Intervals. 


\section{References}

[1] K. Blennow, M.J. de Leon, H. Zetterberg, Alzheimer’s disease, Lancet. 368 (2015) 387403. doi:10.1016/S0140-6736(06)69113-7.

[2] E. Nichols, C.E.I. Szoeke, S.E. Vollset, N. Abbasi, F. Abd-Allah, J. Abdela, M.T.E. Aichour, R.O. Akinyemi, F. Alahdab, S.W. Asgedom, A. Awasthi, S.L. Barker-Collo, B.T. Baune, Y. Béjot, A.B. Belachew, D.A. Bennett, B. Biadgo, A. Bijani, M.S. Bin Sayeed, C. Brayne, D.O. Carpenter, F. Carvalho, F. Catalá-López, E. Cerin, J.Y.J. Choi, A.K. Dang, M.G. Degefa, S. Djalalinia, M. Dubey, E.E. Duken, D. Edvardsson, M.

Endres, S. Eskandarieh, A. Faro, F. Farzadfar, S.M. Fereshtehnejad, E. Fernandes, I. Filip, F. Fischer, A.K. Gebre, D. Geremew, M. Ghasemi-Kasman, E. V. Gnedovskaya, R. Gupta, V. Hachinski, T.B. Hagos, S. Hamidi, G.J. Hankey, J.M. Haro, S.I. Hay, S.S.N. Irvani, R.P. Jha, J.B. Jonas, R. Kalani, A. Karch, A. Kasaeian, Y.S. Khader, I.A. Khalil, E.A. Khan, T. Khanna, T.A.M. Khoja, J. Khubchandani, A. Kisa, K. Kissimova-Skarbek, M. Kivimäki, A. Koyanagi, K.J. Krohn, G. Logroscino, S. Lorkowski, M. Majdan, R. Malekzadeh, W. März, J. Massano, G. Mengistu, A. Meretoja, M. Mohammadi, M. Mohammadi-Khanaposhtani, A.H. Mokdad, S. Mondello, G. Moradi, G. Nagel, M. Naghavi, G. Naik, L.H. Nguyen, T.H. Nguyen, Y.L. Nirayo, M.R. Nixon, R. OforiAsenso, F.A. Ogbo, A.T. Olagunju, M.O. Owolabi, S. Panda-Jonas, V.M. d. A. Passos, D.M. Pereira, G.D. Pinilla-Monsalve, M.A. Piradov, C.D. Pond, H. Poustchi, M. Qorbani, A. Radfar, R.C. Reiner, S.R. Robinson, G. Roshandel, A. Rostami, T.C. Russ, P.S. Sachdev, H. Safari, S. Safiri, R. Sahathevan, Y. Salimi, M. Satpathy, M. Sawhney, M. Saylan, S.G. Sepanlou, A. Shafieesabet, M.A. Shaikh, M.A. Sahraian, M. Shigematsu, R. Shiri, I. Shiue, J.P. Silva, M. Smith, S. Sobhani, D.J. Stein, R. Tabarés-Seisdedos, M.R. Tovani-Palone, B.X. Tran, T.T. Tran, A.T. Tsegay, I. Ullah, N. Venketasubramanian, V. Vlassov, Y.P. Wang, J. Weiss, R. Westerman, T. Wijeratne, G.M.A. Wyper, Y. Yano, E.M. Yimer, N. Yonemoto, M. Yousefifard, Z. Zaidi, Z. Zare, T. Vos, V.L. Feigin, C.J.L. Murray, Global, regional, and national burden of Alzheimer's disease and other dementias, 1990-2016: a systematic analysis for the Global Burden of Disease Study 2016, Lancet Neurol. 18 (2019) 88-106. doi:10.1016/S1474-4422(18)30403-4.

[3] M. Goedert, M.G. Spillantini, A century of Alzheimer's disease., Science. 314 (2006) 777-781. doi:10.1126/science.1132814. 
[4] P. Sorrentino, A. Iuliano, A. Polverino, F. Jacini, G. Sorrentino, The dark sides of amyloid in Alzheimer’s disease pathogenesis, FEBS Lett. 588 (2014) 641-652. doi:10.1016/j.febslet.2013.12.038.

[5] W.I. Rosenblum, Why Alzheimer trials fail: Removing soluble oligomeric beta amyloid is essential, inconsistent, and difficult, Neurobiol. Aging. 35 (2014) 969-974. doi:10.1016/j.neurobiolaging.2013.10.085.

[6] K. Herrup, The case for rejecting the amyloid cascade hypothesis, Nat Neurosci. (2015) 794-799.

[7] M.K. Tiwari, K.P. Kepp, $\beta$-Amyloid pathogenesis: Chemical properties versus cellular levels, Alzheimer’s Dement. 12 (2016) 184-194. doi:10.1016/j.jalz.2015.06.1895.

[8] B. De Strooper, Lessons from a Failed $\gamma$-Secretase Alzheimer Trial, Cell. 159 (2014) 721726. doi:10.1016/j.cell.2014.10.016.

[9] S. Veugelen, T. Saito, T.C. Saido, L. Chávez-Gutiérrez, B. De Strooper, Familial Alzheimer's Disease Mutations in Presenilin Generate Amyloidogenic A $\beta$ Peptide Seeds, Neuron. 90 (2016) 410-416. doi:10.1016/j.neuron.2016.03.010.

[10] K.P. Kepp, Ten Challenges of the Amyloid Hypothesis of Alzheimer's Disease, J. Alzheimer’s Dis. 55 (2017) 447-457. doi:10.3233/JAD-160550.

[11] J. Karlawish, Addressing the ethical, policy, and social challenges of preclinical Alzheimer disease., Neurology. 77 (2011) 1487-1493. doi:10.1212/WNL.0b013e318232ac1a.

[12] S. Karantzoulis, J.E. Galvin, Distinguishing Alzheimer's disease from other major forms of dementia, Expert Rev. Neurother. 11 (2011) 1579-1591. doi:10.1586/ern.11.155.

[13] G.M. McKhann, D.S. Knopman, H. Chertkow, B.T. Hyman, C.R. Jack Jr., C.H. Kawas, W.E. Klunk, W.J. Koroshetz, J.J. Manly, R. Mayeux, R.C. Mohs, J.C. Morris, M.N. Rossor, P. Scheltens, M.C. Carrillo, B. Thies, S. Weintraub, C.H. Phelps, The diagnosis of dementia due to Alzheimer's disease: Recommendations from the National Institute on Aging-Alzheimer's Association workgroups on diagnostic guidelines for Alzheimer’s disease, Alzheimer’s Dement. 7 (2011) 263-269. doi:http://dx.doi.org/10.1016/j.jalz.2011.03.005.

[14] K.P. Kepp, Bioinorganic chemistry of Alzheimer's disease., Chem. Rev. 112 (2012) 5193-5239. doi:10.1021/cr300009x.

[15] J. Hardy, D.J. Selkoe, The amyloid hypothesis of Alzheimer's disease: progress and 
problems on the road to therapeutics., Science 297 (2002) 353-356.

doi:10.1126/science.1072994.

[16] C.L. Masters, D.J. Selkoe, Biochemistry of amyloid $\beta$-protein and amyloid deposits in Alzheimer disease., Cold Spring Harb. Perspect. Med. 2 (2012) a006262.

doi:10.1101/cshperspect.a006262.

[17] M.A. Lovell, J.D. Robertson, W.J. Teesdale, J.L. Campbell, W.R. Markesbery, Copper, iron and zinc in Alzheimer’s disease senile plaques., J. Neurol. Sci. 158 (1998) 47-52.

[18] C. Ballard, S. Gauthier, A. Corbett, C. Brayne, D. Aarsland, E. Jones, Alzheimer’s disease., Lancet. 377 (2011) 1019-1031. doi:10.1016/S0140-6736(10)61349-9.

[19] A. Goate, M.C. Chartier-Harlin, M. Mullan, J. Brown, F. Crawford, L. Fidani, L. Giuffra, A. Haynes, N. Irving, L. James, Segregation of a missense mutation in the amyloid precursor protein gene with familial Alzheimer's disease., Nature. 349 (1991) 704-706. doi:10.1038/349704a0.

[20] M.S. Wolfe, Processive proteolysis by $\gamma$-secretase and the mechanism of Alzheimer's disease, Biol. Chem. 393 (2012) 899-905. doi:10.1515/hsz-2012-0140.

[21] R. Vassar, B.D. Bennett, S. Babu-Khan, S. Kahn, E.A. Mendiaz, P. Denis, D.B. Teplow, S. Ross, P. Amarante, R. Loeloff, Y. Luo, S. Fisher, J. Fuller, S. Edenson, J. Lile, M.A. Jarosinski, A.L. Biere, E. Curran, T. Burgess, J.C. Louis, F. Collins, J. Treanor, G.

Rogers, M. Citron, Beta-secretase cleavage of Alzheimer's amyloid precursor protein by the transmembrane aspartic protease BACE., Science. 286 (1999) 735-741. doi:10.1126/science.286.5440.735.

[22] R. Sherrington, E.I. Rogaev, Y. Liang, E.A. Rogaeva, G. Levesque, M. Ikeda, H. Chi, C. Lin, G. Li, K. Holman, T. Tsuda, L. Mar, J.F. Foncin, A.C. Bruni, M.P. Montesi, S. Sorbi, I. Rainero, L. Pinessi, L. Nee, I. Chumakov, D. Pollen, A. Brookes, P. Sanseau, R.J. Polinsky, W. Wasco, H.A. Da Silva, J.L. Haines, M.A. Perkicak-Vance, R.E. Tanzi, A.D. Roses, P.E. Fraser, J.M. Rommens, P.H. St George-Hyslop, Cloning of a gene bearing missense mutations in early-onset familial Alzheimer’s disease., Nature. 375 (1995) 754 760. doi:10.1038/375754a0.

[23] E. Levy-Lahad, W. Wasco, P. Poorkaj, D.M. Romano, J. Oshima, W.H. Pettingell, C.E. Yu, P.D. Jondro, S.D. Schmidt, K. Wang, et al., Candidate gene for the chromosome 1 familial Alzheimer’s disease locus, Science 269 (1995) 973-977.

doi:10.1126/science.7638622. 
[24] P. Hollingworth, D. Harold, L. Jones, M.J. Owen, J. Williams, Alzheimer's disease genetics: Current knowledge and future challenges, Int. J. Geriatr. Psychiatry. 26 (2011) 793-802. doi:10.1002/gps.2628.

[25] D.C. Ryman, N. Acosta-Baena, P.S. Aisen, T. Bird, A. Danek, N.C. Fox, A. Goate, P. Frommelt, B. Ghetti, J.B.S. Langbaum, F. Lopera, R. Martins, C.L. Masters, R.P. Mayeux, E. McDade, S. Moreno, E.M. Reiman, J.M. Ringman, S. Salloway, P.R. Schofield, R. Sperling, P.N. Tariot, C. Xiong, J.C. Morris, R.J. Bateman, Symptom onset in autosomal dominant Alzheimer disease: A systematic review and meta-analysis, Neurology. 83 (2014) 253-260. doi:10.1212/WNL.0000000000000596.

[26] B. De Strooper, P. Saftig, K. Craessaerts, H. Vanderstichele, G. Guhde, W. Annaert, K. Von Figura, F. Van Leuven, Deficiency of presenilin-1 inhibits the normal cleavage of amyloid precursor protein., Nature. 391 (1998) 387-390. doi:10.1038/34910.

[27] J. Hardy, Alzheimer’s disease: The amyloid cascade hypothesis - An update and reappraisal, J. Alzheimer’s Dis. 9 (2006) 151-153.

[28] E. Karran, M. Mercken, B. De Strooper, The amyloid cascade hypothesis for Alzheimer ' s disease : an appraisal for the development of therapeutics, Nat. Rev. Drug Discov. 10 (2011) 698-712. doi:10.1038/nrd3505.

[29] G.E. Gibson, H.-M. Huang, Oxidative stress in Alzheimer's disease, Neurobiol. Aging. 26 (2005) 575-578. doi:10.1016/j.neurobiolaging.2004.07.017.

[30] I. Ferrer, Altered mitochondria, energy metabolism, voltage-dependent anion channel, and lipid rafts converge to exhaust neurons in Alzheimer’s disease, J. Bioenerg. Biomembr. 41 (2009) 425-431. doi:10.1007/s10863-009-9243-5.

[31] S.M. De la Monte, Type 3 diabetes is sporadic Alzheimer’s disease: Mini-review, Eur. Neuropsychopharmacol. 24 (2014) 1-7. doi:10.1016/j.euroneuro.2014.06.008.

[32] G. Zündorf, G. Reiser, Calcium dysregulation and homeostasis of neural calcium in the molecular mechanisms of neurodegenerative diseases provide multiple targets for neuroprotection., Antioxid. Redox Signal. 14 (2011) 1275-1288. doi:10.1089/ars.2010.3359.

[33] S. Chakroborty, G.E. Stutzmann, Early calcium dysregulation in Alzheimer's disease: Setting the stage for synaptic dysfunction, Sci. China Life Sci. 54 (2011) 752-762. doi:10.1007/s11427-011-4205-7.

[34] D.H. Small, Dysregulation of calcium homeostasis in Alzheimer's disease, Neurochem. 
Res. 34 (2009) 1824-1829. doi:10.1007/s11064-009-9960-5.

[35] M.A. Greenough, J. Camakaris, A.I. Bush, Metal dyshomeostasis and oxidative stress in Alzheimer’s disease., Neurochem. Int. 62 (2013) 540-55.

doi:10.1016/j.neuint.2012.08.014.

[36] J.D. Robertson, A.M. Crafford, W.R. Markesbery, M.A. Lovell, Disruption of zinc homeostasis in Alzheimer's disease, Nucl. Instruments Methods Phys. Res. Sect. B Beam Interact. with Mater. Atoms. 189 (2002) 454-458. doi:10.1016/S0168-583X(01)01124-7.

[37] L.E. Scott, C. Orvig, Medicinal inorganic chemistry approaches to passivation and removal of aberrant metal ions in disease, Chem. Rev. 109 (2009) 4885-4910. doi:10.1021/cr9000176.

[38] P. Zatta, D. Drago, P. Zambenedetti, S. Bolognin, E. Nogara, A. Peruffo, B. Cozzi, Accumulation of copper and other metal ions, and metallothionein I/II expression in the bovine brain as a function of aging, J. Chem. Neuroanat. 36 (2008) 1-5. doi:10.1016/j.jchemneu.2008.02.008.

[39] A. Pal, M. Siotto, R. Prasad, R. Squitti, Towards a unified vision of copper involvement in Alzheimer's disease: a review connecting basic, experimental, and clinical research, J. Alzheimer's Dis. 44 (2015) 343-354.

[40] G.J. Brewer, Copper excess, zinc deficiency, and cognition loss in Alzheimer's disease, BioFactors. 38 (2012) 107-113. doi:10.1002/biof.1005.

[41] G.J. Brewer, S.H. Kanzer, E.A. Zimmerman, E.S. Molho, D.F. Celmins, S.M. Heckman, R. Dick, Subclinical Zinc Deficiency in Alzheimer’s Disease and Parkinson’s Disease, Am. J. Alzheimer’s Dis. Other Dementias. 25 (2010) 572-575. doi:10.1177/1533317510382283.

[42] H. Kozlowski, M. Luczkowski, M. Remelli, D. Valensin, Copper, zinc and iron in neurodegenerative diseases (Alzheimer’s, Parkinson’s and prion diseases), Coord. Chem. Rev. 256 (2012) 2129-2141. doi:10.1016/j.ccr.2012.03.013.

[43] L. Mascitelli, F. Pezzetta, M.R. Goldstein, Iron, type 2 diabetes mellitus, and Alzheimer’s disease, Cell. Mol. Life Sci. 66 (2009) 2943. doi:10.1007/s00018-009-0083-6.

[44] K.S. Kosik, Tau protein and Alzheimer’s disease, Curr. Opin. Cell Biol. 2 (1990) 101104. doi:http://dx.doi.org/10.1016/S0955-0674(05)80038-9.

[45] K.S. Kosik, C.L. Joachim, D.J. Selkoe, Microtubule-associated protein tau (tau) is a major antigenic component of paired helical filaments in Alzheimer disease., Proc. Natl. Acad. 
Sci. U. S. A. 83 (1986) 4044-4048.

[46] R.B. Maccioni, G. Farias, I. Morales, L. Navarrete, The revitalized tau hypothesis on Alzheimer’s disease., Arch. Med. Res. 41 (2010) 226-231.

doi:10.1016/j.arcmed.2010.03.007.

[47] M. Goedert, Tau protein and the neurofibrillary pathology of Alzheimer's disease, Trends Neurosci. 16 (1993) 460-465. doi:http://dx.doi.org/10.1016/0166-2236(93)90078-Z.

[48] A.I. Bush, R.E. Tanzi, Therapeutics for Alzheimer's disease based on the metal hypothesis., Neurotherapeutics. 5 (2008) 421-432. doi:10.1016/j.nurt.2008.05.001.

[49] A.I. Bush, The Metal Theory of Alzheimer's Disease, Rev. Lit. Arts Am. 33 (2013) 277281. doi:10.3233/JAD-2012-129011.

[50] G. Perry, A.D. Cash, M.A. Smith, Alzheimer Disease and Oxidative Stress, J. Biomed. Biotechnol. 2 (2002) 120-123. doi:10.1155/S1110724302203010.

[51] K. Honda, G. Casadesus, R.B. Petersen, G. Perry, M.A. Smith, Oxidative stress and redox-active iron in Alzheimer's disease, Ann. N. Y. Acad. Sci. 1012 (2004) 179-182. doi:10.1196/annals.1306.015.

[52] T. Lu, Y. Pan, S.-Y. Kao, C. Li, I. Kohane, J. Chan, B.A. Yankner, Gene regulation and DNA damage in the ageing human brain., Nature. 429 (2004) 883-891. doi:10.1038/nature02661.

[53] C.M. Opazo, M.A. Greenough, A.I. Bush, Copper: from neurotransmission to neuroproteostasis , Front. Aging Neurosci. . 6 (2014) 143. https://www.frontiersin.org/article/10.3389/fnagi.2014.00143.

[54] V. Vassiliev, Z.L. Harris, P. Zatta, Ceruloplasmin in neurodegenerative diseases, Brain Res. Rev. 49 (2005) 633-640. doi:10.1016/j.brainresrev.2005.03.003.

[55] Z.K. Mathys, A.R. White, Copper and Alzheimer's Disease, in: Adv. Neurobiol., 2017: pp. 199-216. doi:10.1007/978-3-319-60189-2_10.

[56] C. Hureau, Coordination of redox active metal ions to the amyloid precursor protein and to amyloid- $\beta$ peptides involved in Alzheimer disease. Part 1: An overview, Coord. Chem. Rev. 256 (2012) 2164-2174. doi:10.1016/j.ccr.2012.03.037.

[57] R. Squitti, R. Polimanti, M. Siotto, S. Bucossi, M. Ventriglia, S. Mariani, F. Vernieri, F. Scrascia, L. Trotta, P.M. Rossini, ATP7B variants as modulators of copper dyshomeostasis in Alzheimer’s disease, Neuromolecular Med. 15 (2013) 515-522.

[58] R. Squitti, M. Siotto, M. Arciello, L. Rossi, Non-ceruloplasmin bound copper and ATP7B 
gene variants in Alzheimer’s disease, Metallomics. 8 (2016) 863-873.

[59] P. Faller, C. Hureau, Bioinorganic chemistry of copper and zinc ions coordinated to amyloid-beta peptide., Dalt. Trans. (2009) 1080-1094. doi:10.1039/b813398k.

[60] K.P. Kepp, Alzheimer's disease: How metal ions define $\beta$-amyloid function, Coord. Chem. Rev. 351 (2017) 127-159. doi:10.1016/j.ccr.2017.05.007.

[61] C.L. Masters, D.C. Gajdusek, C.J.J. Gibbs, The familial occurrence of Creutzfeldt-Jakob disease and Alzheimer's disease., Brain. 104 (1981) 535-558.

[62] G.G. Glenner, C.W. Wong, Alzheimer's disease: initial report of the purification and characterization of a novel cerebrovascular amyloid protein., Biochem. Biophys. Res. Commun. 120 (1984) 885-890.

[63] J.A. Hardy, G.A. Higgins, Alzheimer's disease: the amyloid cascade hypothesis., Science 256 (1992) 184-185.

[64] A.F. Teich, O. Arancio, Is the Amyloid Hypothesis of Alzheimer's disease therapeutically relevant?, Biochem. J. 446 (2012) 165-177. doi:10.1042/BJ20120653.

[65] R.J. Bateman, L.Y. Munsell, J.C. Morris, R. Swarm, K.E. Yarasheski, D.M. Holtzman, Human amyloid-beta synthesis and clearance rates as measured in cerebrospinal fluid in vivo., Nat. Med. 12 (2006) 856-861. doi:10.1038/nm1438.

[66] M.D. Carter, G.A. Simms, D.F. Weaver, The development of new therapeutics for Alzheimer’s disease., Clin. Pharmacol. Ther. 88 (2010) 475-486. doi:10.1038/clpt.2010.165.

[67] J.-S. Choi, J.J. Braymer, R.P.R. Nanga, A. Ramamoorthy, M.H. Lim, Design of small molecules that target metal-A $\beta$ species and regulate metal-induced $\mathrm{A} \beta$ aggregation and neurotoxicity., Proc. Natl. Acad. Sci. U. S. A. 107 (2010) 21990-21995. doi:10.1073/pnas.1006091107.

[68] A.S. DeToma, S. Salamekh, A. Ramamoorthy, M.H. Lim, Misfolded proteins in Alzheimer's disease and type II diabetes, Chem. Soc. Rev. 41 (2012) 608-621. doi:10.1039/c1cs15112f.

[69] A. Ramamoorthy, M.H. Lim, Structural characterization and inhibition of toxic amyloid- $\beta$ oligomeric intermediates, Biophys. J. 105 (2013) 287-288. doi:10.1016/j.bpj.2013.05.004.

[70] B.P. Imbimbo, G.A.M. Giardina, gamma-secretase inhibitors and modulators for the treatment of Alzheimer's disease: disappointments and hopes., Curr. Top. Med. Chem. 11 (2011) 1555-1570. 
[71] J. Nunan, D.H. Small, Regulation of APP cleavage by alpha-, beta- and gammasecretases., FEBS Lett. 483 (2000) 6-10.

[72] N. Tang, A.K. Somavarapu, K.P. Kepp, Molecular Recipe for $\gamma$-Secretase Modulation from Computational Analysis of 60 Active Compounds, ACS Omega. 3 (2018) 1807818088. doi:10.1021/acsomega.8b02196.

[73] T.E. Golde, L.S. Schneider, E.H. Koo, Anti-A $\beta$ therapeutics in alzheimer's disease: The need for a paradigm shift, Neuron. 69 (2011) 203-213. doi:10.1016/j.neuron.2011.01.002.

[74] M.W. Beck, J.S. Derrick, R.A. Kerr, S.B. Oh, W.J. Cho, S.J.C. Lee, Y. Ji, J. Han, Z.A. Tehrani, N. Suh, S. Kim, S.D. Larsen, K.S. Kim, J.-Y. Lee, B.T. Ruotolo, M.H. Lim, Structure-mechanism-based engineering of chemical regulators targeting distinct pathological factors in Alzheimer’s disease, Nat. Commun. 7 (2016) 13115. https://doi.org/10.1038/ncomms13115.

[75] J. Kang, S.J.C. Lee, J.S. Nam, H.J. Lee, M.-G. Kang, K.J. Korshavn, H.-T. Kim, J. Cho, A. Ramamoorthy, H.-W. Rhee, T.-H. Kwon, M.H. Lim, An Iridium(III) Complex as a Photoactivatable Tool for Oxidation of Amyloidogenic Peptides with Subsequent Modulation of Peptide Aggregation, Chem. - A Eur. J. 23 (2017) 1645-1653. doi:10.1002/chem.201604751.

[76] J.S. Derrick, R.A. Kerr, Y. Nam, S.B. Oh, H.J. Lee, K.G. Earnest, N. Suh, K.L. Peck, M. Ozbil, K.J. Korshavn, A. Ramamoorthy, R. Prabhakar, E.J. Merino, J. Shearer, J.-Y. Lee, B.T. Ruotolo, M.H. Lim, A Redox-Active, Compact Molecule for Cross-Linking Amyloidogenic Peptides into Nontoxic, Off-Pathway Aggregates: In Vitro and In Vivo Efficacy and Molecular Mechanisms, J. Am. Chem. Soc. 137 (2015) 14785-14797. doi:10.1021/jacs.5b10043.

[77] L. Chávez-Gutiérrez, L. Bammens, I. Benilova, A. Vandersteen, M. Benurwar, M. Borgers, S. Lismont, L. Zhou, S. Van Cleynenbreugel, H. Esselmann, J. Wiltfang, L. Serneels, E. Karran, H. Gijsen, J. Schymkowitz, F. Rousseau, K. Broersen, B. De Strooper, The mechanism of $\gamma$-secretase dysfunction in familial Alzheimer disease, EMBO J. 31 (2012) 2261-2274. doi:10.1038/emboj.2012.79.

[78] L. Sun, R. Zhou, G. Yang, Y. Shi, Analysis of 138 pathogenic mutations in presenilin-1 on the in vitro production of $A \beta 42$ and $A \beta 40$ peptides by $\gamma$-secretase, Proc. Natl. Acad. Sci. 114 (2016) E476-E485. doi:10.1073/pnas.1618657114.

[79] M. Takami, Y. Nagashima, Y. Sano, S. Ishihara, M. Morishima-Kawashima, S. 
Funamoto, Y. Ihara, $\gamma$-Secretase: successive tripeptide and tetrapeptide release from the transmembrane domain of $\beta$-carboxyl terminal fragment., J. Neurosci. 29 (2009) 1304213052. doi:10.1523/JNEUROSCI.2362-09.2009.

[80] A. Fukumori, R. Fluhrer, H. Steiner, C. Haass, Three-amino acid spacing of presenilin endoproteolysis suggests a general stepwise cleavage of gamma-secretase-mediated intramembrane proteolysis., J. Neurosci. 30 (2010) 7853-7862. doi:10.1523/JNEUROSCI.1443-10.2010.

[81] C. Haass, C. Kaether, G. Thinakaran, S. Sisodia, Trafficking and proteolytic processing of APP., Cold Spring Harb. Perspect. Med. 2 (2012) a006270. doi:10.1101/cshperspect.a006270.

[82] M.A. Fernandez, J.A. Klutkowski, T. Freret, M.S. Wolfe, Alzheimer Presenilin-1 Mutations Dramatically Reduce Trimming of Long Amyloid $\beta$-Peptides (A $\beta$ ) by $\gamma$ Secretase to Increase 42-to-40-Residue A $\beta$, J. Biol. Chem. 289 (2014) 31043-31052. doi:10.1074/jbc.M114.581165.

[83] M. Cacquevel, L. Aeschbach, J. Houacine, P.C. Fraering, Alzheimer's disease-linked mutations in presenilin-1 result in a drastic loss of activity in purified $\gamma$-secretase complexes, PLoS One. 7 (2012) 1-13. doi:10.1371/journal.pone.0035133.

[84] G. Woodruff, J.E. Young, F.J. Martinez, F. Buen, A. Gore, J. Kinaga, Z. Li, S.H. Yuan, K. Zhang, L.S.B. Goldstein, The Presenilin-1 $\delta E 9$ Mutation Results in Reduced $\gamma$-Secretase Activity, but Not Total Loss of PS1 Function, in Isogenic Human Stem Cells, Cell Rep. 5 (2013) 974-985. doi:10.1016/j.celrep.2013.10.018.

[85] M. Bentahir, O. Nyabi, J. Verhamme, A. Tolia, K. Horre, J. Wiltfang, H. Esselmann, B. De Strooper, Presenilin clinical mutations can affect gamma-secretase activity by different mechanisms., J. Neurochem. 96 (2006) 732-742. doi:10.1111/j.1471-4159.2005.03578.x.

[86] A. Jan, O. Gokce, R. Luthi-Carter, H.A. Lashuel, The ratio of monomeric to aggregated forms of $A \beta 40$ and $A \beta 42$ is an important determinant of amyloid- $\beta$ aggregation, fibrillogenesis, and toxicity, J. Biol. Chem. 283 (2008) 28176-28189. doi:10.1074/jbc.M803159200.

[87] F. Chiti, C.M. Dobson, Protein misfolding, functional amyloid, and human disease., Annu. Rev. Biochem. 75 (2006) 333-366. doi:10.1146/annurev.biochem.75.101304.123901.

[88] A. Rauk, The chemistry of Alzheimer’s disease., Chem. Soc. Rev. 38 (2009) 2698-2715. doi:10.1039/b807980n. 
[89] M.K. Tiwari, K.P. Kepp, Modeling the Aggregation Propensity and Toxicity of Amyloid$\beta$ Variants, J. Alzheimer’s Dis. 47 (2015) 215-229. doi:10.3233/JAD-150046.

[90] A.K. Somavarapu, K.P. Kepp, Direct Correlation of Cell Toxicity to Conformational Ensembles of Genetic A $\beta$ Variants, ACS Chem. Neurosci. 6 (2015) 1990-1996. doi:10.1021/acschemneuro.5b00238.

[91] N. Tang, K.P. Kepp, A $\beta 42 / A \beta 40$ ratios of presenilin 1 mutations correlate with clinical onset of Alzheimer's disease, J. Alzheimer's Dis. 66 (2018) 939-945.

[92] H.J. Aizenstein, R.D. Nebes, J.A. Saxton, J.C. Price, C.A. Mathis, N.D. Tsopelas, S.K. Ziolko, J.A. James, B.E. Snitz, P.R. Houck, W. Bi, A.D. Cohen, B.J. Lopresti, S.T. DeKosky, E.M. Halligan, W.E. Klunk, Frequent amyloid deposition without significant cognitive impairment among the elderly., Arch. Neurol. 65 (2008) 1509-1517. doi:10.1001/archneur.65.11.1509.

[93] F.H. Bouwman, N.S.M. Schoonenboom, N.A. Verwey, E.J. van Elk, A. Kok, M.A. Blankenstein, P. Scheltens, W.M. van der Flier, CSF biomarker levels in early and late onset Alzheimer's disease., Neurobiol. Aging. 30 (2009) 1895-1901. doi:10.1016/j.neurobiolaging.2008.02.007.

[94] J.L. Price, D.W.J. McKeel, V.D. Buckles, C.M. Roe, C. Xiong, M. Grundman, L.A. Hansen, R.C. Petersen, J.E. Parisi, D.W. Dickson, C.D. Smith, D.G. Davis, F.A. Schmitt, W.R. Markesbery, J. Kaye, R. Kurlan, C. Hulette, B.F. Kurland, R. Higdon, W. Kukull, J.C. Morris, Neuropathology of nondemented aging: presumptive evidence for preclinical Alzheimer disease., Neurobiol. Aging. 30 (2009) 1026-1036. doi:10.1016/j.neurobiolaging.2009.04.002.

[95] T. Gomez-Isla, R. Hollister, H. West, S. Mui, J.H. Growdon, R.C. Petersen, J.E. Parisi, B.T. Hyman, Neuronal loss correlates with but exceeds neurofibrillary tangles in Alzheimer’s disease., Ann. Neurol. 41 (1997) 17-24. doi:10.1002/ana.410410106.

[96] C. Schmitz, B.P.F. Rutten, A. Pielen, S. Schafer, O. Wirths, G. Tremp, C. Czech, V. Blanchard, G. Multhaup, P. Rezaie, H. Korr, H.W.M. Steinbusch, L. Pradier, T.A. Bayer, Hippocampal neuron loss exceeds amyloid plaque load in a transgenic mouse model of Alzheimer’s disease., Am. J. Pathol. 164 (2004) 1495-1502. doi:10.1016/S00029440(10)63235-X.

[97] B.A. Yankner, L.R. Dawes, S. Fisher, L. Villa-Komaroff, M.L. Oster-Granite, R.L. Neve, Neurotoxicity of a fragment of the amyloid precursor associated with Alzheimer's 
disease., Science. 245 (1989) 417-420. doi:10.1126/science.2474201.

[98] R. Kayed, E. Head, J.L. Thompson, T.M. McIntire, S.C. Milton, C.W. Cotman, C.G. Glabe, Common structure of soluble amyloid oligomers implies common mechanism of pathogenesis., Science. 300 (2003) 486-489. doi:10.1126/science.1079469.

[99] S. Lesne, M.T. Koh, L. Kotilinek, R. Kayed, C.G. Glabe, A. Yang, M. Gallagher, K.H. Ashe, A specific amyloid-beta protein assembly in the brain impairs memory., Nature. 440 (2006) 352-357. doi:10.1038/nature04533.

[100] L.W. Hung, G.D. Ciccotosto, E. Giannakis, D.J. Tew, K. Perez, C.L. Masters, R. Cappai, J.D. Wade, K.J. Barnham, Amyloid-beta peptide $(A \beta)$ neurotoxicity is modulated by the rate of peptide aggregation: Abeta dimers and trimers correlate with neurotoxicity., J. Neurosci. 28 (2008) 11950-11958. doi:10.1523/JNEUROSCI.3916-08.2008.

[101] F. Panza, V. Frisardi, D. Seripa, B.P. Imbimbo, D. Sancarlo, G. D’Onofrio, F. Addante, F. Paris, A. Pilotto, V. Solfrizzi, Metabolic Syndrome, Mild Cognitive Impairment and Dementia, Curr. Alzheimer Res. 8 (2011) 492-509.

[102] S.J.C. Lee, E. Nam, H.J. Lee, M.G. Savelieff, M.H. Lim, Towards an understanding of amyloid- $\beta$ oligomers: characterization, toxicity mechanisms, and inhibitors, Chem. Soc. Rev. 46 (2017) 310-323.

[103] A.R.A. Ladiwala, J. Litt, R.S. Kane, D.S. Aucoin, S.O. Smith, S. Ranjan, J. Davis, W.E. Van Nostrand, P.M. Tessier, Conformational differences between two amyloid beta oligomers of similar size and dissimilar toxicity., J. Biol. Chem. 287 (2012) 24765-24773. doi:10.1074/jbc.M111.329763.

[104] M. Townsend, G.M. Shankar, T. Mehta, D.M. Walsh, D.J. Selkoe, Effects of secreted oligomers of amyloid beta-protein on hippocampal synaptic plasticity: a potent role for trimers., J. Physiol. 572 (2006) 477-492. doi:10.1113/jphysiol.2005.103754.

[105] D.M. Walsh, D.J. Selkoe, A beta oligomers - a decade of discovery., J. Neurochem. 101 (2007) 1172-1184. doi:10.1111/j.1471-4159.2006.04426.x.

[106] C. Haass, D.J. Selkoe, Soluble protein oligomers in neurodegeneration: lessons from the Alzheimer’s amyloid beta-peptide., Nat. Rev. Mol. Cell Biol. 8 (2007) 101-112. doi:10.1038/nrm2101.

[107] W.E. Balch, R.I. Morimoto, A. Dillin, J.W. Kelly, Adapting proteostasis for disease intervention., Science. 319 (2008) 916-919. doi:10.1126/science.1141448.

[108] J. Götz, A. Eckert, M. Matamales, L.M. Ittner, X. Liu, Modes of A $\beta$ toxicity in 
Alzheimer’s disease, Cell. Mol. Life Sci. 68 (2011) 3359-3375. doi:10.1007/s00018-0110750-2.

[109] Y. Yoshiike, D.H. Chui, T. Akagi, N. Tanaka, A. Takashima, Specific compositions of amyloid- $\beta$ peptides as the determinant of toxic A $\beta$-aggregation, J. Biol. Chem. 278 (2003) 23648-23655. doi:10.1074/jbc.M212785200.

[110] L. Lecanu, J. Greeson, V. Papadopoulos, Beta-amyloid and oxidative stress jointly induce neuronal death, amyloid deposits, gliosis, and memory impairment in the rat brain., Pharmacology. 76 (2006) 19-33. doi:10.1159/000088929.

[111] D.P. Smith, D.G. Smith, C.C. Curtain, J.F. Boas, J.R. Pilbrow, G.D. Ciccotosto, T.L. Lau, D.J. Tew, K. Perez, J.D. Wade, A.I. Bush, S.C. Drew, F. Separovic, C.L. Masters, R. Cappai, K.J. Barnham, Copper-mediated amyloid-beta toxicity is associated with an intermolecular histidine bridge, J. Biol. Chem. 281 (2006) 15145-15154. doi:10.1074/jbc.M600417200.

[112] P. Faller, C. Hureau, Metal ions in neurodegenerative diseases, Coord. Chem. Rev. 256 (2012) 2127-2128. doi:10.1016/j.ccr.2012.04.006.

[113] S.C. Drew, C.J. Noble, C.L. Masters, G.R. Hanson, K.J. Barnham, Pleomorphic Copper Coordination by Alzheimer's Disease Amyloid- $\beta$ Peptide, J. Am. Chem. Soc. 131 (2009) 1195-1207. doi:10.1021/ja808073b.

[114] C.G. Glabe, Common mechanisms of amyloid oligomer pathogenesis in degenerative disease., Neurobiol. Aging. 27 (2006) 570-575. doi:10.1016/j.neurobiolaging.2005.04.017.

[115] M.F.M. Sciacca, S.A. Kotler, J.R. Brender, J. Chen, D.K. Lee, A. Ramamoorthy, Twostep mechanism of membrane disruption by $\mathrm{A} \beta$ through membrane fragmentation and pore formation, Biophys. J. 103 (2012) 702-710. doi:10.1016/j.bpj.2012.06.045.

[116] N. Arispe, E. Rojas, H.B. Pollard, Alzheimer disease amyloid beta protein forms calcium channels in bilayer membranes: blockade by tromethamine and aluminum., Proc. Natl. Acad. Sci. U. S. A. 90 (1993) 567-571. doi:10.1073/pnas.90.2.567.

[117] A. Quist, I. Doudevski, H. Lin, R. Azimova, D. Ng, B. Frangione, B. Kagan, J. Ghiso, R. Lal, Amyloid ion channels: a common structural link for protein-misfolding disease., Proc. Natl. Acad. Sci. U. S. A. 102 (2005) 10427-10432. doi:10.1073/pnas.0502066102.

[118] J.R. Brender, S. Salamekh, A. Ramamoorthy, Membrane disruption and early events in the aggregation of the diabetes related peptide IAPP from a molecular perspective, Acc. 
Chem. Res. 45 (2012) 454-462. doi:10.1021/ar200189b.

[119] I.W. Hamley, The amyloid beta peptide: a chemist's perspective. Role in Alzheimer's and fibrillization., Chem. Rev. 112 (2012) 5147-5192. doi:10.1021/cr3000994.

[120] A.K. Somavarapu, K.P. Kepp, The Dependence of Amyloid-beta Dynamics on Protein Force Fields and Water Models., Chemphyschem. 16 (2015) 3278-3289. doi:10.1002/cphc.201500415.

[121] A. Deshpande, E. Mina, C. Glabe, J. Busciglio, Different conformations of amyloid beta induce neurotoxicity by distinct mechanisms in human cortical neurons., J. Neurosci. 26 (2006) 6011-6018. doi:10.1523/JNEUROSCI.1189-06.2006.

[122] O. Crescenzi, S. Tomaselli, R. Guerrini, S. Salvadori, A.M. D’Ursi, P.A. Temussi, D. Picone, Solution structure of the Alzheimer amyloid $\beta$-peptide (1-42) in an apolar microenvironment: Similarity with a virus fusion domain, Eur. J. Biochem. 269 (2002) 5642-5648. doi:10.1046/j.1432-1033.2002.03271.x.

[123] S. Tomaselli, V. Esposito, P. Vangone, N.A.J. Van Nuland, A.M.J.J. Bonvin, R. Guerrini, T. Tancredi, P.A. Temussi, D. Picone, The $\alpha$-to- $\beta$ conformational transition of Alzheimer's A $\beta-(1-42)$ peptide in aqueous media is reversible: A step by step conformational analysis suggests the location of $\beta$ conformation seeding, ChemBioChem. 7 (2006) 257-267. doi:10.1002/cbic.200500223.

[124] D.J. Rosenman, C.R. Connors, W. Chen, C. Wang, A.E. García, A $\beta$ monomers transiently sample oligomer and fibril-like configurations: Ensemble characterization using a combined MD/NMR approach, J. Mol. Biol. 425 (2013) 3338-3359. doi:10.1016/j.jmb.2013.06.021.

[125] M. Coles, W. Bicknell, A.A. Watson, D.P. Fairlie, D.J. Craik, Solution structure of amyloid beta-peptide(1-40) in a water-micelle environment., Biochemistry. 37 (1998) 11064-77. doi:10.1021/bi972979f.

[126] S. Vivekanandan, J.R. Brender, S.Y. Lee, A. Ramamoorthy, A partially folded structure of amyloid- $\beta(1-40)$ in an aqueous environment, Biochem. Biophys. Res. Commun. 411 (2011) 312-316. doi:10.1016/j.bbrc.2011.06.133.

[127] H. Sticht, P. Bayer, D. Willbold, S. Dames, C. Hilbich, K. Beyreuther, R.W. Frank, P. Rosch, Structure of amyloid A4-(1-40)-peptide of Alzheimer’s disease., Eur. J. Biochem. 233 (1995) 293-298.

[128] M. Kawahara, N. Arispe, Y. Kuroda, E. Rojas, Alzheimer’s disease amyloid beta-protein 
forms $\mathrm{Zn}(2+)$-sensitive, cation-selective channels across excised membrane patches from hypothalamic neurons., Biophys. J. 73 (1997) 67-75. doi:10.1016/S0006-3495(97)780482.

[129] S.K. Rhee, A.P. Quist, R. Lal, Amyloid beta protein-(1-42) forms calcium-permeable, Zn2+-sensitive channel., J. Biol. Chem. 273 (1998) 13379-13382.

[130] N. Arispe, H.B. Pollard, E. Rojas, Zn2+ interaction with Alzheimer amyloid beta protein calcium channels, Proc. Natl. Acad. Sci. . 93 (1996) 1710-1715. http://www.pnas.org/content/93/4/1710.abstract.

[131] J.-M. Suh, G. Kim, J. Kang, M.H. Lim, Strategies Employing Transition Metal Complexes To Modulate Amyloid- $\beta$ Aggregation, Inorg. Chem. 58 (2019) 8-17. doi:10.1021/acs.inorgchem.8b02813.

[132] A.S. Pithadia, M.H. Lim, Metal-associated amyloid- $\beta$ species in Alzheimer's disease, Curr. Opin. Chem. Biol. 16 (2012) 67-73.

[133] S.-J. Hyung, A.S. DeToma, J.R. Brender, S. Lee, S. Vivekanandan, A. Kochi, J.-S. Choi, A. Ramamoorthy, B.T. Ruotolo, M.H. Lim, Insights into antiamyloidogenic properties of the green tea extract (-)-epigallocatechin-3-gallate toward metal-associated amyloid- $\beta$ species, Proc. Natl. Acad. Sci. 110 (2013) 3743-3748.

[134] J.T. Rubino, K.J. Franz, Coordination chemistry of copper proteins: how nature handles a toxic cargo for essential function, J. Inorg. Biochem. 107 (2012) 129-143.

[135] E. Gaggelli, H. Kozlowski, D. Valensin, G. Valensin, Copper Homeostasis and Neurodegenerative Disorders (Alzheimers, Prion, and Parkinsons Diseases and Amyotrophic Lateral Sclerosis), Chem. Rev. 106 (2006) 1995-2044. doi:10.1021/cr040410w.

[136] M. Siotto, R. Squitti, Copper imbalance in Alzheimer's disease: Overview of the exchangeable copper component in plasma and the intriguing role albumin plays, Coord. Chem. Rev. 371 (2018) 86-95.

[137] E.I. Solomon, D.E. Heppner, E.M. Johnston, J.W. Ginsbach, J. Cirera, M. Qayyum, M.T. Kieber-Emmons, C.H. Kjaergaard, R.G. Hadt, L. Tian, Copper active sites in biology., Chem. Rev. 114 (2014) 3659-3853. doi:10.1021/cr400327t.

[138] M.G. Savelieff, G. Nam, J. Kang, H.J. Lee, M. Lee, M.H. Lim, Development of multifunctional molecules as potential therapeutic candidates for alzheimer's disease, parkinson's disease, and amyotrophic lateral sclerosis in the last decade, Chem. Rev. 119 
(2018) 1221-1322.

[139] S.O. Dahms, I. Konnig, D. Roeser, K.-H. Guhrs, M.C. Mayer, D. Kaden, G. Multhaup, M.E. Than, Metal binding dictates conformation and function of the amyloid precursor protein (APP) E2 domain., J. Mol. Biol. 416 (2012) 438-452.

doi:10.1016/j.jmb.2011.12.057.

[140] S. Zong, M. Wu, J. Gu, T. Liu, R. Guo, M. Yang, Structure of the intact 14-subunit human cytochrome c oxidase, Cell Res. 28 (2018) 1026.

[141] G.K.W. Kong, J.J. Adams, H.H. Harris, J.F. Boas, C.C. Curtain, D. Galatis, C.L. Masters, K.J. Barnham, W.J. McKinstry, R. Cappai, M.W. Parker, Structural Studies of the Alzheimer's Amyloid Precursor Protein Copper-binding Domain Reveal How it Binds Copper Ions, J. Mol. Biol. 367 (2007) 148-161. doi:10.1016/j.jmb.2006.12.041.

[142] R.W. Strange, S. V Antonyuk, M.A. Hough, P.A. Doucette, J.S. Valentine, S.S. Hasnain, Variable metallation of human superoxide dismutase: atomic resolution crystal structures of Cu-Zn, Zn-Zn and as-isolated wild-type enzymes., J. Mol. Biol. 356 (2006) 1152-62. doi:10.1016/j.jmb.2005.11.081.

[143] L. Banci, I. Bertini, R. Del Conte, M. D’Onofrio, A. Rosato, Solution Structure and Backbone Dynamics of the $\mathrm{Cu}(\mathrm{I})$ and Apo Forms of the Second Metal-Binding Domain of the Menkes Protein ATP7A, Biochemistry. 43 (2004) 3396-3403. doi:10.1021/bi036042s.

[144] K.J. Barnham, W.J. McKinstry, G. Multhaup, D. Galatis, C.J. Morton, C.C. Curtain, N. a. Williamson, A.R. White, M.G. Hinds, R.S. Norton, K. Beyreuther, C.L. Masters, M.W. Parker, R. Cappai, Structure of the Alzheimer's disease amyloid precursor protein copper binding domain. A regulator of neuronal copper homeostasis, J. Biol. Chem. 278 (2003) 17401-17407. doi:10.1074/jbc.M300629200.

[145] J. Hidalgo, M. Aschner, P. Zatta, M. Vašák, Roles of the metallothionein family of proteins in the central nervous system, Brain Res. Bull. 55 (2001) 133-145. doi:http://dx.doi.org/10.1016/S0361-9230(01)00452-X.

[146] A.C. Hall, B.W. Young, I. Bremner, Intestinal metallothionein and the mutual antagonism between copper and zinc in the rat, J. Inorg. Biochem. 11 (1979) 57-66. doi:http://dx.doi.org/10.1016/S0162-0134(00)80054-9.

[147] R.S. Chung, C. Howells, E.D. Eaton, L. Shabala, K. Zovo, P. Palumaa, R. Sillard, A. Woodhouse, W.R. Bennett, S. Ray, The native copper-and zinc-binding protein metallothionein blocks copper-mediated $\mathrm{A} \beta$ aggregation and toxicity in rat cortical 
neurons, PLoS One. 5 (2010) e12030.

[148] P. Oestreicher, R.J. Cousins, Copper and zinc absorption in the rat: mechanism of mutual antagonism, J. Nutr. 115 (1985) 159-166.

[149] Y. Qin, P.J. Dittmer, J.G. Park, K.B. Jansen, A.E. Palmer, Measuring steady-state and dynamic endoplasmic reticulum and Golgi Zn2+ with genetically encoded sensors, Proc. Natl. Acad. Sci. 108 (2011) 7351-7356.

[150] A. Takeda, K. Yamada, H. Tamano, S. Fuke, M. Kawamura, N. Oku, Hippocampal calcium dyshomeostasis and long-term potentiation in 2-week zinc deficiency, Neurochem. Int. 52 (2008) 241-246.

[151] G.J. Brewer, S.H. Kanzer, E.A. Zimmerman, D.F. Celmins, S.M. Heckman, R. Dick, Copper and ceruloplasmin abnormalities in Alzheimer’s disease, Am. J. Alzheimer's Dis. Other Dementias. 25 (2010) 490-497.

[152] M.L. Schlief, J.D. Gitlin, Copper homeostasis in the CNS, Mol. Neurobiol. 33 (2006) 8190.

[153] S. Lutsenko, Human copper homeostasis: a network of interconnected pathways, Curr. Opin. Chem. Biol. 14 (2010) 211-217.

[154] H. Kodama, Y. Meguro, T. Abe, M.H. Rayner, K.T. Suzuki, S. Kobayashi, M. Nishimura, Genetic expression of Menkes disease in cultured astrocytes of the macular mouse, $\mathrm{J}$. Inherit. Metab. Dis. 14 (1991) 896-901.

[155] E. Tiffany-Castiglioni, S. Hong, Y. Qian, Copper handling by astrocytes: Insights into neurodegenerative diseases, Int. J. Dev. Neurosci. 29 (2011) 811-818. doi:10.1016/j.ijdevneu.2011.09.004.

[156] J. Telianidis, Y.H. Hung, S. Materia, S. La Fontaine, Role of the P-Type ATPases, ATP7A and ATP7B in brain copper homeostasis, Front. Aging Neurosci. 5 (2013) 44.

[157] M.J. Niciu, X.-M. Ma, R. El Meskini, G. V Ronnett, R.E. Mains, B.A. Eipper, Developmental changes in the expression of ATP7A during a critical period in postnatal neurodevelopment, Neuroscience. 139 (2006) 947-964.

[158] S.G. Kaler, ATP7A-related copper transport diseases-emerging concepts and future trends, Nat. Rev. Neurol. 7 (2011) 15.

[159] N. D’Ambrosi, L. Rossi, Copper at synapse: release, binding and modulation of neurotransmission, Neurochem. Int. 90 (2015) 36-45.

[160] N. Barnes, R. Tsivkovskii, N. Tsivkovskaia, S. Lutsenko, The copper-transporting 
ATPases, Menkes and Wilson disease proteins, have distinct roles in adult and developing cerebellum, J. Biol. Chem. 280 (2005) 9640-9645.

[161] N. Salès, K. Rodolfo, R. Hässig, B. Faucheux, L. Di Giamberardino, K.L. Moya, Cellular prion protein localization in rodent and primate brain, Eur. J. Neurosci. 10 (1998) 24642471.

[162] M.P. Hornshaw, J.R. McDermott, J.M. Candy, Copper binding to the N-terminal tandem repeat regions of mammalian and avian prion protein, Biochem. Biophys. Res. Commun. 207 (1995) 621-629.

[163] M.P. Hornshaw, J.R. McDermott, J.M. Candy, J.H. Lakey, Copper binding to the Nterminal tandem repeat region of mammalian and avian prion protein: structural studies using synthetic peptides, Biochem. Biophys. Res. Commun. 214 (1995) 993-999.

[164] D.R. Brown, K. Qin, J.W. Herms, A. Madlung, J. Manson, R. Strome, P.E. Fraser, T. Kruck, A. von Bohlen, W. Schulz-Schaeffer, The cellular prion protein binds copper in vivo, Nature. 390 (1997) 684.

[165] D.R. Brown, C. Clive, S.J. Haswell, Antioxidant activity related to copper binding of native prion protein, J. Neurochem. 76 (2001) 69-76.

[166] G.L. Millhauser, Copper and the prion protein: methods, structures, function, and disease., Annu. Rev. Phys. Chem. 58 (2007) 299-320.

doi:10.1146/annurev.physchem.58.032806.104657.

[167] H.A. Kretzschmar, T. Tings, A. Madlung, A. Giese, J. Herms, Function of PrP C as a copper-binding protein at the synapse, in: Prion Dis., Springer, 2000: pp. 239-249.

[168] N. Vassallo, J. Herms, Cellular prion protein function in copper homeostasis and redox signalling at the synapse, J. Neurochem. 86 (2003) 538-544.

[169] H. You, S. Tsutsui, S. Hameed, T.J. Kannanayakal, L. Chen, P. Xia, J.D.T. Engbers, S. a. Lipton, P.K. Stys, G.W. Zamponi, A $\beta$ neurotoxicity depends on interactions between copper ions, prion protein, and N-methyl-D-aspartate receptors, Proc. Natl. Acad. Sci. 109 (2012) 1737-1742. doi:10.1073/pnas.1110789109.

[170] H.W. Kessels, L.N. Nguyen, S. Nabavi, R. Malinow, The prion protein as a receptor for amyloid- $\beta$, Nature. 466 (2010) E3.

[171] J. Stöckel, J. Safar, A.C. Wallace, F.E. Cohen, S.B. Prusiner, Prion protein selectively binds copper (II) ions, Biochemistry. 37 (1998) 7185-7193.

[172] J.H. Viles, F.E. Cohen, S.B. Prusiner, D.B. Goodin, P.E. Wright, H.J. Dyson, Copper 
binding to the prion protein: structural implications of four identical cooperative binding sites, Proc. Natl. Acad. Sci. 96 (1999) 2042-2047.

[173] S.B. Prusiner, Novel proteinaceous infectious particles cause scrapie, Science 216 (1982) 136-144.

[174] D.E. Hartter, A. Barnea, Evidence for release of copper in the brain: Depolarizationinduced release of newly taken-up 67copper, Synapse. 2 (1988) 412-415. doi:10.1002/syn.890020408.

[175] A. Hopt, S. Korte, H. Fink, U. Panne, R. Niessner, R. Jahn, H. Kretzschmar, J. Herms, Methods for studying synaptosomal copper release, J. Neurosci. Methods. 128 (2003) 159-172.

[176] D.R. Brown, Prion and prejudice: normal protein and the synapse, Trends Neurosci. 24 (2001) 85-90.

[177] L. Gasperini, E. Meneghetti, B. Pastore, F. Benetti, G. Legname, Prion protein and copper cooperatively protect neurons by modulating NMDA receptor through S-nitrosylation, Antioxid. Redox Signal. 22 (2015) 772-784.

[178] P.C. Pauly, D.A. Harris, Copper stimulates endocytosis of the prion protein, J. Biol. Chem. 273 (1998) 33107-33110.

[179] K. Balamurugan, W. Schaffner, Copper homeostasis in eukaryotes: Teetering on a tightrope, Biochim. Biophys. Acta - Mol. Cell Res. 1763 (2006) 737-746. doi:http://dx.doi.org/10.1016/j.bbamcr.2006.05.001.

[180] T.D. Rae, P.J. Schmidt, R.A. Pufahl, V.C. Culotta, T. V O’halloran, Undetectable intracellular free copper: the requirement of a copper chaperone for superoxide dismutase, Science 284 (1999) 805-808.

[181] X. Huang, M.P. Cuajungco, C.S. Atwood, M.A. Hartshorn, J.D.A. Tyndall, G.R. Hanson, K.C. Stokes, M. Leopold, G. Multhaup, L.E. Goldstein, R.C. Scarpa, A.J. Saunders, J. Lim, R.D. Moir, C. Glabe, E.F. Bowden, C.L. Masters, D.P. Fairlie, R.E. Tanzi, A.I. Bush, $\mathrm{Cu}(\mathrm{II})$ Potentiation of Alzheimer A $\beta$ Neurotoxicity: Correlation with cell-free hydrogen peroxide production and metal reduction, J. Biol. Chem. 274 (1999) 3711137116. http://www.jbc.org/content/274/52/37111.abstract.

[182] G. Multhaup, T. Ruppert, A. Schlicksupp, L. Hesse, E. Bill, R. Pipkorn, C.L. Masters, K. Beyreuther, Copper-binding amyloid precursor protein undergoes a site-specific fragmentation in the reduction of hydrogen peroxide, Biochemistry. 37 (1998) 7224-7230. 
doi:10.1021/bi980022m.

[183] Z. Xiao, F. Loughlin, G.N. George, G.J. Howlett, A.G. Wedd, C-terminal domain of the membrane copper transporter Ctr1 from Saccharomyces cerevisiae binds four $\mathrm{Cu}$ (I) ions as a cuprous-thiolate polynuclear cluster: sub-femtomolar $\mathrm{Cu}$ (I) affinity of three proteins involved in copper trafficking, J. Am. Chem. Soc. 126 (2004) 3081-3090.

[184] D. Terwel, Y. Löschmann, H.H. Schmidt, H.R. Schöler, T. Cantz, M.T. Heneka, Neuroinflammatory and behavioural changes in the Atp7B mutant mouse model of Wilson's disease, J. Neurochem. 118 (2011) 105-112.

[185] K. Schmidt, M. Ralle, T. Schaffer, S. Jayakanthan, B. Bari, A. Muchenditsi, S. Lutsenko, ATP7A and ATP7B copper transporters have distinct functions in the regulation of neuronal dopamine- $\beta$-hydroxylase, J. Biol. Chem. 293 (2018) 20085-20098.

[186] T. Saito, T. Nagao, M. Okabe, K. Saito, Neurochemical and histochemical evidence for an abnormal catecholamine metabolism in the cerebral cortex of the Long-Evans Cinnamon rat before excessive copper accumulation in the brain, Neurosci. Lett. 216 (1996) 195198.

[187] M.C. Linder, Ceruloplasmin and other copper binding components of blood plasma and their functions: an update, Metallomics. 8 (2016) 887-905.

[188] J. Masuoka, J. Hegenauer, B.R. Van Dyke, P. Saltman, Intrinsic stoichiometric equilibrium constants for the binding of zinc (II) and copper (II) to the high affinity site of serum albumin., J. Biol. Chem. 268 (1993) 21533-21537.

[189] N. Liu, L.S. Lo, S.H. Askary, L. Jones, T.Z. Kidane, T. Trang, M. Nguyen, J. Goforth, Y.H. Chu, E. Vivas, M. Tsai, T. Westbrook, M.C. Linder, Transcuprein is a macroglobulin regulated by copper and iron availability, J. Nutr. Biochem. 18 (2007) 597-608. doi:10.1016/j.jnutbio.2006.11.005.

[190] J. Kardos, I. Kovács, F. Hajós, M. Kálmán, M. Simonyi, Nerve endings from rat brain tissue release copper upon depolarization. A possible role in regulating neuronal excitability, Neurosci. Lett. 103 (1989) 139-144.

[191] C.R. Capo, M. Arciello, R. Squitti, E. Cassetta, P.M. Rossini, L. Calabrese, L. Rossi, Features of ceruloplasmin in the cerebrospinal fluid of Alzheimer's disease patients, BioMetals. 21 (2008) 367-372. doi:10.1007/s10534-007-9125-4.

[192] H.J. Stuerenburg, CSF copper concentrations, blood-brain barrier function, and coeruloplasmin synthesis during the treatment of Wilson’s disease, J. Neural Transm. 107 
(2000) 321-329.

[193] J.H. Viles, Metal ions and amyloid fiber formation in neurodegenerative diseases. Copper, zinc and iron in Alzheimer's, Parkinson's and prion diseases, Coord. Chem. Rev. 256 (2012) 2271-2284. doi:10.1016/j.ccr.2012.05.003.

[194] C.G. Dudzik, E.D. Walter, G.L. Millhauser, Coordination features and affinity of the $\mathrm{Cu} 2+$ site in the $\alpha$-synuclein protein of Parkinson's disease, Biochemistry. 50 (2011) 1771-1777.

[195] H. Irving, R.J.P. Williams, The stability of transition-metal complexes, J. Chem. Soc. (1953) 3192-3210. doi:10.1039/JR9530003192.

[196] A. Ala, A.P. Walker, K. Ashkan, J.S. Dooley, M.L. Schilsky, Wilson’s disease, Lancet. 369 (2007) 397-408.

[197] R. Squitti, R. Ghidoni, I. Simonelli, I.D. Ivanova, N.A. Colabufo, M. Zuin, L. Benussi, G. Binetti, E. Cassetta, M. Rongioletti, Copper dyshomeostasis in Wilson disease and Alzheimer's disease as shown by serum and urine copper indicators, J. Trace Elem. Med. Biol. 45 (2018) 181-188.

[198] V.A. Streltsov, R.S.K. Ekanayake, S.C. Drew, C.T. Chantler, S.P. Best, Structural Insight into Redox Dynamics of Copper Bound N-Truncated Amyloid- $\beta$ Peptides from in Situ Xray Absorption Spectroscopy, Inorg. Chem. 57 (2018) 11422-11435. doi:10.1021/acs.inorgchem.8b01255.

[199] S.C. Drew, C.L. Masters, K.J. Barnham, Alzheimer’s Abeta peptides with diseaseassociated N-terminal modifications: influence of isomerisation, truncation and mutation on Cu2+ coordination., PLoS One. 5 (2010) e15875. doi:10.1371/journal.pone.0015875.

[200] N.E. Wezynfeld, E. Stefaniak, K. Stachucy, A. Drozd, D. Płonka, S.C. Drew, A. Krężel, W. Bal, Resistance of $\mathrm{Cu}(\mathrm{A} \beta 4-16)$ to Copper Capture by Metallothionein-3 Supports a Function for the A $\beta 4-42$ Peptide as a Synaptic CuII Scavenger, Angew. Chemie Int. Ed. 55 (2016) 8235-8238. doi:10.1002/anie.201511968.

[201] M. Mital, N.E. Wezynfeld, T. Frączyk, M.Z. Wiloch, U.E. Wawrzyniak, A. Bonna, C. Tumpach, K.J. Barnham, C.L. Haigh, W. Bal, S.C. Drew, A Functional Role for A $\beta$ in Metal Homeostasis? N-Truncation and High-Affinity Copper Binding, Angew. Chemie Int. Ed. 54 (2015) 10460-10464.

[202] L.-E. Cassagnes, V. Hervé, F. Nepveu, C. Hureau, P. Faller, F. Collin, The Catalytically Active Copper-Amyloid-Beta State: Coordination Site Responsible for Reactive Oxygen 
Species Production, Angew. Chemie Int. Ed. 52 (2013) 11110-11113.

doi:10.1002/anie.201305372.

[203] C. Hureau, P. Dorlet, Coordination of redox active metal ions to the amyloid precursor protein and to amyloid- $\beta$ peptides involved in Alzheimer disease. Part 2: Dependence of $\mathrm{Cu}$ (II) binding sites with A $\beta$ sequences, Coord. Chem. Rev. 256 (2012) 2175-2187.

[204] D.T. Richens, Ligand substitution reactions at inorganic centers, Chem. Rev. 105 (2005) 1961-2002.

[205] A. Conte-Daban, M. Beyler, R. Tripier, C. Hureau, Kinetics are crucial when targeting copper ions to fight Alzheimer’s disease: an illustration with azamacrocyclic ligands, Chem. Eur. J. 24 (2018) 8447-8452.

[206] A.K. Somavarapu, F. Shen, K. Teilum, J. Zhang, S. Mossin, P.W. Thulstrup, M.J. Bjerrum, M.K. Tiwari, D. Szunyogh, P.M. Søtofte, K.P. Kepp, L. Hemmingsen, The Pathogenic A2V Mutant Exhibits Distinct Aggregation Kinetics, Metal Site Structure, and Metal Exchange of the Cu2+-A $\beta$ Complex, Chem. - A Eur. J. 23 (2017) 13591-13595. doi:10.1002/chem.201703440.

[207] S. Bucossi, M. Ventriglia, V. Panetta, C. Salustri, P. Pasqualetti, S. Mariani, M. Siotto, P.M. Rossini, R. Squitti, Copper in Alzheimer's disease: a meta-analysis of serum, plasma, and cerebrospinal fluid studies, J. Alzheimer’s Dis. 24 (2011) 175-185.

[208] M. Schrag, C. Mueller, U. Oyoyo, M.A. Smith, W.M. Kirsch, Iron, zinc and copper in the Alzheimer's disease brain: a quantitative meta-analysis. Some insight on the influence of citation bias on scientific opinion, Prog. Neurobiol. 94 (2011) 296-306.

[209] R. Squitti, I. Simonelli, M. Ventriglia, M. Siotto, P. Pasqualetti, A. Rembach, J. Doecke, A.I. Bush, Meta-analysis of serum non-ceruloplasmin copper in Alzheimer's disease, J. Alzheimer's Dis. 38 (2014) 809-822.

[210] J. Wang, L. Tan, H.-F. Wang, C.-C. Tan, X.-F. Meng, C. Wang, S.-W. Tang, J.-T. Yu, Anti-inflammatory drugs and risk of Alzheimer's disease: an updated systematic review and meta-analysis, J. Alzheimer's Dis. 44 (2015) 385-396.

[211] D.-D. Li, W. Zhang, Z.-Y. Wang, P. Zhao, Serum copper, zinc, and iron levels in patients with Alzheimer's disease: a meta-analysis of case-control studies, Front. Aging Neurosci. 9 (2017) 300.

[212] R. Squitti, R. Ghidoni, M. Siotto, M. Ventriglia, L. Benussi, A. Paterlini, M. Magri, G. Binetti, E. Cassetta, D. Caprara, Value of serum nonceruloplasmin copper for prediction 
of mild cognitive impairment conversion to Alzheimer disease, Ann. Neurol. 75 (2014) $574-580$.

[213] M. Schrag, C. Mueller, M. Zabel, A. Crofton, W.M. Kirsch, O. Ghribi, R. Squitti, G. Perry, Oxidative stress in blood in Alzheimer's disease and mild cognitive impairment: a meta-analysis, Neurobiol. Dis. 59 (2013) 100-110.

[214] S.A. James, I. Volitakis, P.A. Adlard, J.A. Duce, C.L. Masters, R.A. Cherny, A.I. Bush, Elevated labile $\mathrm{Cu}$ is associated with oxidative pathology in Alzheimer disease, Free Radic. Biol. Med. 52 (2012) 298-302.

[215] A. Rembach, D.J. Hare, M. Lind, C.J. Fowler, R.A. Cherny, C. McLean, A.I. Bush, C.L. Masters, B.R. Roberts, Decreased copper in Alzheimer's disease brain is predominantly in the soluble extractable fraction, Int. J. Alzheimer’s Dis. 2013 (2013).

[216] J. Xu, S.J. Church, S. Patassini, P. Begley, H.J. Waldvogel, M.A. Curtis, R.L.M. Faull, R.D. Unwin, G.J.S. Cooper, Evidence for widespread, severe brain copper deficiency in Alzheimer’s dementia, Metallomics. 9 (2017) 1106-1119.

[217] M. Siotto, I. Simonelli, P. Pasqualetti, S. Mariani, D. Caprara, S. Bucossi, M. Ventriglia, R. Molinario, M. Antenucci, M. Rongioletti, Association between serum ceruloplasmin specific activity and risk of Alzheimer’s disease, J. Alzheimer’s Dis. 50 (2016) 11811189.

[218] G. Torsdottir, J. Kristinsson, J. Snaedal, T. Jóhannesson, Ceruloplasmin and iron proteins in the serum of patients with Alzheimer's disease, Dement. Geriatr. Cogn. Dis. Extra. 1 (2011) 366-371.

[219] R. Squitti, M. Siotto, E. Cassetta, I.G. El Idrissi, N.A. Colabufo, Measurements of serum non-ceruloplasmin copper by a direct fluorescent method specific to $\mathrm{Cu}$ (II), Clin. Chem. Lab. Med. 55 (2017) 1360-1367.

[220] J. Snaedal, J. Kristinsson, S. Gunnarsdottir, A. Olafsdottir, M. Baldvinsson, T. Johannesson, Copper, ceruloplasmin and superoxide dismutase in patients with Alzheimer’s disease, Dement. Geriatr. Cogn. Disord. 9 (1998) 239-242.

[221] K. Nakamura, N. Go, Function and molecular evolution of multicopper blue proteins, Cell. Mol. Life Sci. 62 (2005) 2050-2066. doi:10.1007/s00018-004-5076-X.

[222] D.J. Waggoner, T.B. Bartnikas, J.D. Gitlin, The role of copper in neurodegenerative disease., Neurobiol. Dis. 6 (1999) 221-230. doi:10.1006/nbdi.1999.0250.

[223] B.N. Patel, S. David, A novel glycosylphosphatidylinositol-anchored form of 
ceruloplasmin is expressed by mammalian astrocytes, J. Biol. Chem. 272 (1997) 2018520190.

[224] H.P. Roeser, G.R. Lee, S. Nacht, G.E. Cartwright, The role of ceruloplasmin in iron metabolism, J. Clin. Invest. 49 (1970) 2408-2417. doi:10.1172/JCI106460.

[225] P. Bielli, L. Calabrese, Structure to function relationships in ceruloplasmin: a’moonlighting'protein, Cell. Mol. Life Sci. C. 59 (2002) 1413-1427.

[226] R. Squitti, C.C. Quattrocchi, G.D. Forno, P. Antuono, D.R. Wekstein, C.R. Capo, C. Salustri, P.M. Rossini, Ceruloplasmin (2-D PAGE) pattern and copper content in serum and brain of Alzheimer disease patients, Biomark. Insights. 1 (2006) 117727190600100020.

[227] S.W. Mercer, J. Wang, R. Burke, In Vivo Modeling of the Pathogenic Effect of Copper Transporter Mutations That Cause Menkes and Wilson Diseases, Motor Neuropathy, and Susceptibility to Alzheimer’s Disease, J. Biol. Chem. 292 (2017) 4113-4122.

[228] R. Squitti, P. Pasqualetti, G. Dal Forno, F. Moffa, E. Cassetta, D. Lupoi, F. Vernieri, L. Rossi, M. Baldassini, P.M. Rossini, Excess of serum copper not related to ceruloplasmin in Alzheimer disease, Neurology. 64 (2005) 1040-1046.

[229] R. Squitti, P. Pasqualetti, R. Polimanti, C. Salustri, F. Moffa, E. Cassetta, D. Lupoi, M. Ventriglia, M. Cortesi, M. Siotto, Metal-score as a potential non-invasive diagnostic test for Alzheimer’s disease, Curr. Alzheimer Res. 10 (2013) 191-198.

[230] R. Squitti, F. Bressi, P. Pasqualetti, C. Bonomini, R. Ghidoni, G. Binetti, E. Cassetta, F. Moffa, M. Ventriglia, F. Vernieri, Longitudinal prognostic value of serum “free” copper in patients with Alzheimer disease, Neurology. 72 (2009) 50-55.

[231] R. Squitti, R. Ghidoni, F. Scrascia, L. Benussi, V. Panetta, P. Pasqualetti, F. Moffa, S. Bernardini, M. Ventriglia, G. Binetti, Free copper distinguishes mild cognitive impairment subjects from healthy elderly individuals, J. Alzheimer’s Dis. 23 (2011) 239-248.

[232] L. Rozzini, F. Lanfranchi, A. Pilotto, S. Catalani, M.E. Gilberti, M. Paganelli, P. Apostoli, A. Padovani, Serum non-ceruloplasmin non-albumin copper elevation in mild cognitive impairment and dementia due to Alzheimer's disease: a case control study, J. Alzheimer’s Dis. 61 (2018) 907-912.

[233] X.-L. Shen, J.-H. Yu, D.-F. Zhang, J.-X. Xie, H. Jiang, Positive Relationship between Mortality from Alzheimer's Disease and Soil Metal Concentration in Mainland China, J. Alzheimers Dis. J. Alzheimer’s Dis. J. Alzheimers Dis, J Alzheim D, J Alzheimers Dis, J. 
Alzheimers Dis. J Alzheimer’s Dis. 42 (2014) 893-900. doi:10.3233/jad-140153.

[234] M.C. Morris, D.A. Evans, C.C. Tangney, J.L. Bienias, J.A. Schneider, R.S. Wilson, P.A. Scherr, Dietary copper and high saturated and trans fat intakes associated with cognitive decline, Arch. Neurol. 63 (2006) 1085-1088.

[235] P.K. Lam, D. Kritz-Silverstein, E. Barrett-Connor, D. Milne, F. Nielsen, A. Gamst, D. Morton, D. Wingard, Plasma trace elements and cognitive function in older men and women: the Rancho Bernardo study, J. Nutr. Heal. Aging. 12 (2008) 22-27.

[236] G. Zhou, X. Ji, N. Cui, S. Cao, C. Liu, J. Liu, Association between serum copper status and working memory in schoolchildren, Nutrients. 7 (2015) 7185-7196.

[237] M. Kicinski, J. Vrijens, G. Vermier, E. Den Hond, G. Schoeters, V. Nelen, L. Bruckers, I. Sioen, W. Baeyens, N. Van Larebeke, Neurobehavioral function and low-level metal exposure in adolescents, Int. J. Hyg. Environ. Health. 218 (2015) 139-146.

[238] H. Takeuchi, Y. Taki, R. Nouchi, R. Yokoyama, Y. Kotozaki, S. Nakagawa, A. Sekiguchi, K. Iizuka, Y. Yamamoto, S. Hanawa, Association of copper levels in the hair with gray matter volume, mean diffusivity, and cognitive functions, Brain Struct. Funct. (2019) 115.

[239] C. Salustri, G. Barbati, R. Ghidoni, L. Quintiliani, S. Ciappina, G. Binetti, R. Squitti, Is cognitive function linked to serum free copper levels? A cohort study in a normal population, Clin. Neurophysiol. 121 (2010) 502-507.

[240] S.L. Sensi, A. Granzotto, M. Siotto, R. Squitti, Copper and Zinc Dysregulation in Alzheimer’s Disease, Trends Pharmacol. Sci. 39 (2018) 1049-1063.

[241] R. Squitti, I. Simonelli, E. Cassetta, D. Lupoi, M. Rongioletti, M. Ventriglia, M. Siotto, Patients with increased non-ceruloplasmin copper appear a distinct sub-group of Alzheimer's disease: a neuroimaging study, Curr. Alzheimer Res. 14 (2017) 1318-1326.

[242] R. Squitti, M. Ventriglia, M. Siotto, C. Salustri, Copper in Alzheimer’s Disease, in: Biometals Neurodegener. Dis., Elsevier, 2017: pp. 19-34.

[243] R. Squitti, M. Ventriglia, M. Gennarelli, N.A. Colabufo, I.G. El Idrissi, S. Bucossi, S. Mariani, M. Rongioletti, O. Zanetti, C. Congiu, Non-ceruloplasmin copper distincts subtypes in Alzheimer's disease: a genetic study of ATP7B frequency, Mol. Neurobiol. 54 (2017) 671-681.

[244] I. Singh, A.P. Sagare, M. Coma, D. Perlmutter, R. Gelein, R.D. Bell, R.J. Deane, E. Zhong, M. Parisi, J. Ciszewski, R.T. Kasper, R. Deane, Low levels of copper disrupt brain 
amyloid-beta homeostasis by altering its production and clearance., Proc. Natl. Acad. Sci. U. S. A. 110 (2013) 14771-14776. doi:10.1073/pnas.1302212110.

[245] T. Hartmann, J. Kuchenbecker, M.O.W. Grimm, Alzheimer’s disease: the lipid connection., J. Neurochem. 103 Suppl (2007) 159-170. doi:10.1111/j.14714159.2007.04715.x.

[246] L.M. Refolo, M.A. Pappolla, J. LaFrancois, B. Malester, S.D. Schmidt, T. ThomasBryant, G.S. Tint, R. Wang, M. Mercken, S.S. Petanceska, A cholesterol-lowering drug reduces $\beta$-amyloid pathology in a transgenic mouse model of Alzheimer's disease, Neurobiol. Dis. 8 (2001) 890-899.

[247] D.L. Sparks, S.W. Scheff, J.C. Hunsaker III, H. Liu, T. Landers, D.R. Gross, Induction of Alzheimer-like $\beta$-amyloid immunoreactivity in the brains of rabbits with dietary cholesterol, Exp. Neurol. 126 (1994) 88-94.

[248] L.M. Refolo, M.A. Pappolla, B. Malester, J. LaFrancois, T. Bryant-Thomas, R. Wang, G.S. Tint, K. Sambamurti, K. Duff, Hypercholesterolemia accelerates the Alzheimer’s amyloid pathology in a transgenic mouse model, Neurobiol. Dis. 7 (2000) 321-331.

[249] D.L. Sparks, J. Lochhead, D. Horstman, T. Wagoner, T. Martin, Water quality has a pronounced effect on cholesterol-induced accumulation of Alzheimer amyloid $\beta(A \beta)$ in rabbit brain, J. Alzheimer’s Dis. 4 (2002) 523-529.

[250] D.L. Sparks, B.G. Schreurs, Trace amounts of copper in water induce beta-amyloid plaques and learning deficits in a rabbit model of Alzheimer's disease., Proc. Natl. Acad. Sci. U. S. A. 100 (2003) 11065-11069. doi:10.1073/pnas.1832769100.

[251] D.L. Sparks, R. Friedland, S. Petanceska, B.G. Schreurs, J. Shi, G. Perry, M.A. Smith, A. Sharma, S. DeRosa, C. Ziolkowski, G. Stankovic, Trace copper levels in the drinking water, but not zinc or aluminum influence CNS Alzheimer-like pathology., J. Nutr. Heal. Aging. 10 (2006) 247-254.

[252] X. Huang, C.S. Atwood, R.D. Moir, M.A. Hartshorn, R.E. Tanzi, A.I. Bush, Trace metal contamination initiates the apparent auto-aggregation, amyloidosis, and oligomerization of Alzheimer's A $\beta$ peptides, J. Biol. Inorg. Chem. 9 (2004) 954-960.

[253] J. Hidalgo, J. Carrasco, A. Quintana, A. Molinero, S. Florit, M. Giralt, A. Ortega-Aznar, Metallothionein I, II and III in Alzheimer Disease and Animal Models of Neuroinflammation, Exp. Biol. Med. (2006) 1450-1458.

[254] P. Zambenedetti, R. Giordano, P. Zatta, Metallothioneins are highly expressed in 
astrocytes and microcapillaries in Alzheimer's disease, J. Chem. Neuroanat. 15 (1998) 21-26.

[255] B. Ruttkay-Nedecky, L. Nejdl, J. Gumulec, O. Zitka, M. Masarik, T. Eckschlager, M. Stiborova, V. Adam, R. Kizek, The role of metallothionein in oxidative stress., Int. J. Mol. Sci. 14 (2013) 6044-66. doi:10.3390/ijms14036044.

[256] M. Vašák, G. Meloni, Chemistry and biology of mammalian metallothioneins, J. Biol. Inorg. Chem. 16 (2011) 1067.

[257] G. Meloni, P. Faller, M. Vašák, Redox silencing of copper in metal-linked neurodegenerative disorders: Reaction of Zn7metallothionein-3 with Cu2+ ions, J. Biol. Chem. 282 (2007) 16068-16078. doi:10.1074/jbc.M701357200.

[258] M. Vašák, G. Meloni, Mammalian metallothionein-3: New functional and structural insights, Int. J. Mol. Sci. 18 (2017) 1117.

[259] W.H. Yu, W.J. Lukiw, C. Bergeron, H.B. Niznik, P.E. Fraser, Metallothionein III is reduced in Alzheimer's disease, Brain Res. 894 (2001) 37-45.

[260] H.G. Kim, Y.P. Hwang, E.H. Han, C.Y. Choi, C.Y. Yeo, J.Y. Kim, K.Y. Lee, H.G. Jeong, Metallothionein-III provides neuronal protection through activation of nuclear factor- $\kappa \mathrm{B}$ via the TrkA/phosphatidylinositol-3 kinase/Akt signaling pathway, Toxicol. Sci. 112 (2009) 435-449. doi:10.1093/toxsci/kfp230.

[261] G. Meloni, V. Sonois, T. Delaine, L. Guilloreau, A. Gillet, J. Teissié, P. Faller, M. Vašák, Metal swap between Zn7-metallothionein-3 and amyloid- $\beta-\mathrm{Cu}$ protects against amyloid- $\beta$ toxicity, Nat. Chem. Biol. 4 (2008) 366-372.

[262] B. Midthune, S.-H. Tyan, J.J. Walsh, F. Sarsoza, S. Eggert, P.R. Hof, D.L. Dickstein, E.H. Koo, Deletion of the amyloid precursor-like protein 2 (APLP2) does not affect hippocampal neuron morphology or function., Mol. Cell. Neurosci. 49 (2012) 448-455. doi:10.1016/j.mcn.2012.02.001.

[263] S. Heber, J. Herms, V. Gajic, J. Hainfellner, A. Aguzzi, T. Rulicke, H. von Kretzschmar, C. von Koch, S. Sisodia, P. Tremml, H.P. Lipp, D.P. Wolfer, U. Muller, Mice with combined gene knock-outs reveal essential and partially redundant functions of amyloid precursor protein family members., J. Neurosci. 20 (2000) 7951-7963.

[264] M. Korte, U. Herrmann, X. Zhang, A. Draguhn, The role of APP and APLP for synaptic transmission, plasticity, and network function: lessons from genetic mouse models., Exp. Brain Res. 217 (2012) 435-440. doi:10.1007/s00221-011-2894-6. 
[265] C.S. von Koch, H. Zheng, H. Chen, M. Trumbauer, G. Thinakaran, L.H. van der Ploeg, D.L. Price, S.S. Sisodia, Generation of APLP2 KO mice and early postnatal lethality in APLP2/APP double KO mice., Neurobiol. Aging. 18 (1997) 661-669.

[266] X. Zhang, U. Herrmann, S.W. Weyer, M. Both, U.C. Muller, M. Korte, A. Draguhn, Hippocampal network oscillations in APP/APLP2-deficient mice., PLoS One. 8 (2013) e61198. doi:10.1371/journal.pone.0061198.

[267] G.R. Dawson, G.R. Seabrook, H. Zheng, D.W. Smith, S. Graham, G. O’Dowd, B.J. Bowery, S. Boyce, M.E. Trumbauer, H.Y. Chen, L.H. Van der Ploeg, D.J. Sirinathsinghji, Age-related cognitive deficits, impaired long-term potentiation and reduction in synaptic marker density in mice lacking the beta-amyloid precursor protein., Neuroscience. 90 (1999) 1-13.

[268] M.L. Giuffrida, F. Caraci, B. Pignataro, S. Cataldo, P. De Bona, V. Bruno, G. Molinaro, G. Pappalardo, A. Messina, A. Palmigiano, D. Garozzo, F. Nicoletti, E. Rizzarelli, A. Copani, $\beta$-Amyloid Monomers Are Neuroprotective, J. Neurosci. 29 (2009) 10582-10587. doi:10.1523/JNEUROSCI.1736-09.2009.

[269] G. Mitteregger, J. Herms, H.A. Kretzschmar, B. Krebs, C. Priller, T. Bauer, Synapse Formation and Function Is Modulated by the Amyloid Precursor Protein, J. Neurosci. 26 (2006) 7212-7221. doi:10.1523/jneurosci.1450-06.2006.

[270] S.W. Weyer, M. Klevanski, A. Delekate, V. Voikar, D. Aydin, M. Hick, M. Filippov, N. Drost, K.L. Schaller, M. Saar, M.A. Vogt, P. Gass, A. Samanta, A. Jaschke, M. Korte, D.P. Wolfer, J.H. Caldwell, U.C. Muller, APP and APLP2 are essential at PNS and CNS synapses for transmission, spatial learning and LTP., EMBO J. 30 (2011) 2266-2280. doi:10.1038/emboj.2011.119.

[271] J.E. Morley, S.A. Farr, W.A. Banks, S.N. Johnson, K.A. Yamada, L. Xu, A physiological role for amyloid- $\beta$ protein: Enhancement of learning and memory, J. Alzheimer's Dis. 19 (2010) 441-449. doi:10.3233/JAD-2010-1230.

[272] K. Zou, J.-S. Gong, K. Yanagisawa, M. Michikawa, A novel function of monomeric amyloid $\beta$-protein serving as an antioxidant molecule against metal-induced oxidative damage, J. Neurosci. 22 (2002) 4833-4841.

[273] H.A. Pearson, C. Peers, Physiological roles for amyloid beta peptides., J. Physiol. 575 (2006) 5-10. doi:10.1113/jphysiol.2006.111203.

[274] E. Abramov, I. Dolev, H. Fogel, G.D. Ciccotosto, E. Ruff, I. Slutsky, Amyloid-beta as a 
positive endogenous regulator of release probability at hippocampal synapses., Nat. Neurosci. 12 (2009) 1567-1576. doi:10.1038/nn.2433.

[275] B.A. Yankner, L.K. Duffy, D.A. Kirschner, Neurotrophic and neurotoxic effects of amyloid beta protein: reversal by tachykinin neuropeptides., Science. 250 (1990) 279-282.

[276] M.A. Smith, G. Casadesus, J.A. Joseph, G. Perry, Amyloid- $\beta$ and $\tau$ serve antioxidant functions in the aging and Alzheimer brain, Free Radic. Biol. Med. 33 (2002) 1194-1199. doi:http://dx.doi.org/10.1016/S0891-5849(02)01021-3.

[277] K.P. Kepp, Alzheimer's disease due to loss of function: A new synthesis of the available data, Prog. Neurobiol. 143 (2016) 36-60. doi:10.1016/j.pneurobio.2016.06.004.

[278] L.D. Plant, J.P. Boyle, I.F. Smith, C. Peers, H.A. Pearson, The production of amyloid beta peptide is a critical requirement for the viability of central neurons., J. Neurosci. 23 (2003) 5531-5535.

[279] D. Kaden, L.M. Munter, B. Reif, G. Multhaup, The amyloid precursor protein and its homologues: structural and functional aspects of native and pathogenic oligomerization., Eur. J. Cell Biol. 91 (2012) 234-239. doi:10.1016/j.ejcb.2011.01.017.

[280] L. Hesse, D. Beher, C.L. Masters, G. Multhaup, The beta A4 amyloid precursor protein binding to copper., FEBS Lett. 349 (1994) 109-116.

[281] S.O. Dahms, S. Hoefgen, D. Roeser, B. Schlott, K.-H. Guhrs, M.E. Than, Structure and biochemical analysis of the heparin-induced E1 dimer of the amyloid precursor protein., Proc. Natl. Acad. Sci. U. S. A. 107 (2010) 5381-5386. doi:10.1073/pnas.0911326107.

[282] V. Tõugu, P. Palumaa, Coordination of zinc ions to the key proteins of neurodegenerative diseases: A $\beta$, APP, $\alpha$-synuclein and PrP, Coord. Chem. Rev. 256 (2012) 2219-2224. doi:10.1016/j.ccr.2011.12.008.

[283] G.K.-W. Kong, J.J. Adams, R. Cappai, M.W. Parker, Structure of Alzheimer's disease amyloid precursor protein copper-binding domain at atomic resolution., Acta Crystallogr. Sect. F. Struct. Biol. Cryst. Commun. 63 (2007) 819-824. doi:10.1107/S1744309107041139.

[284] A.I. Bush, G. Multhaup, R.D. Moir, T.G. Williamson, D.H. Small, B. Rumble, P. Pollwein, K. Beyreuther, C.L. Masters, A novel zinc(II) binding site modulates the function of the beta A4 amyloid protein precursor of Alzheimer's disease., J. Biol. Chem. 268 (1993) 16109-16112.

[285] M.C. Mayer, D. Kaden, L. Schauenburg, M.A. Hancock, P. Voigt, D. Roeser, C. 
Barucker, M.E. Than, M. Schaefer, G. Multhaup, Novel zinc-binding site in the E2 domain regulates amyloid precursor-like protein 1 (APLP1) oligomerization., J. Biol. Chem. 289 (2014) 19019-19030. doi:10.1074/jbc.M114.570382.

[286] G. Multhaup, A. Schlicksupp, L. Hesse, D. Beher, T. Ruppert, C.L. Masters, K. Beyreuther, The amyloid precursor protein of Alzheimer's disease in the reduction of copper(II) to copper(I), Science. 271 (1996) 1406-1409.

[287] C.E. Ooi, E. Rabinovich, A. Dancis, J.S. Bonifacino, R.D. Klausner, Copper-dependent degradation of the Saccharomyces cerevisiae plasma membrane copper transporter Ctr1p in the apparent absence of endocytosis., EMBO J. 15 (1996) 3515-3523.

[288] A.R. White, R. Reyes, J.F.B. Mercer, J. Camakaris, H. Zheng, A.I. Bush, G. Multhaup, K. Beyreuther, C.L. Masters, R. Cappai, Copper levels are increased in the cerebral cortex and liver of APP and APLP2 knockout mice, Brain Res. 842 (1999) 439-444.

[289] R. Squitti, G. Barbati, L. Rossi, M. Ventriglia, G. Dal Forno, S. Cesaretti, F. Moffa, I. Caridi, E. Cassetta, P. Pasqualetti, Excess of nonceruloplasmin serum copper in AD correlates with MMSE, CSF $\beta$-amyloid, and h-tau, Neurology. 67 (2006) 76-82.

[290] D. Strozyk, L.J. Launer, P.A. Adlard, R.A. Cherny, A. Tsatsanis, I. Volitakis, K. Blennow, H. Petrovitch, L.R. White, A.I. Bush, Zinc and copper modulate Alzheimer A $\beta$ levels in human cerebrospinal fluid, Neurobiol. Aging. 30 (2009) 1069-1077.

[291] A.R. White, G. Multhaup, F. Maher, S. Bellingham, J. Camakaris, H. Zheng, A.I. Bush, K. Beyreuther, C.L. Masters, R. Cappai, The Alzheimer's disease amyloid precursor protein modulates copper-induced toxicity and oxidative stress in primary neuronal cultures, J. Neurosci. 19 (1999) 9170-9179. http://www.jneurosci.org/content/19/21/9170.short.

[292] M. Suazo, C. Hodar, C. Morgan, W. Cerpa, V. Cambiazo, N.C. Inestrosa, M. Gonzalez, Overexpression of amyloid precursor protein increases copper content in HEK293 cells, Biochem. Biophys. Res. Commun. 382 (2009) 740-744.

[293] C.J. Maynard, R. Cappai, I. Volitakis, R.A. Cherny, A.R. White, K. Beyreuther, C.L. Masters, A.I. Bush, Q.-X. Li, Overexpression of Alzheimer’s disease amyloid-beta opposes the age-dependent elevations of brain copper and iron., J. Biol. Chem. 277 (2002) 44670-44676. doi:10.1074/jbc.M204379200.

[294] C. Treiber, A. Simons, M. Strauss, M. Hafner, R. Cappai, T.A. Bayer, G. Multhaup, Clioquinol mediates copper uptake and counteracts copper efflux activities of the amyloid 
precursor protein of Alzheimer’s disease., J. Biol. Chem. 279 (2004) 51958-51964. doi:10.1074/jbc.M407410200.

[295] W.F. Cerpa, M.I. Barria, M.A. Chacon, M. Suazo, M. Gonzalez, C. Opazo, A.I. Bush, N.C. Inestrosa, The N-terminal copper-binding domain of the amyloid precursor protein protects against Cu2+ neurotoxicity in vivo., FASEB J. 18 (2004) 1701-1703. doi:10.1096/fj.03-1349fje.

[296] M. Lang, Q. Fan, L. Wang, Y. Zheng, G. Xiao, X. Wang, W. Wang, Y. Zhong, B. Zhou, Inhibition of human high-affinity copper importer Ctr1 orthologous in the nervous system of Drosophila ameliorates Abeta42-induced Alzheimer's disease-like symptoms., Neurobiol. Aging. 34 (2013) 2604-2612. doi:10.1016/j.neurobiolaging.2013.05.029.

[297] J.D. Buxbaum, A.A. Ruefli, C.A. Parker, A.M. Cypess, P. Greengard, Calcium regulates processing of the Alzheimer amyloid protein precursor in a protein kinase C-independent manner., Proc. Natl. Acad. Sci. U. S. A. 91 (1994) 4489-4493.

[298] M.P. Mattson, B. Cheng, A.R. Culwell, F.S. Esch, I. Lieberburg, R.E. Rydel, Evidence for excitoprotective and intraneuronal calcium-regulating roles for secreted forms of the betaamyloid precursor protein., Neuron. 10 (1993) 243-254.

[299] H.S. Kim, C.H. Park, S.H. Cha, J.H. Lee, S. Lee, Y. Kim, J.C. Rah, S.J. Jeong, Y.H. Suh, Carboxyl-terminal fragment of Alzheimer’s APP destabilizes calcium homeostasis and renders neuronal cells vulnerable to excitotoxicity., FASEB J. 14 (2000) 1508-1517.

[300] T. Kanekiyo, C.-C. Liu, M. Shinohara, J. Li, G. Bu, LRP1 in brain vascular smooth muscle cells mediates local clearance of Alzheimer's amyloid-beta., J. Neurosci. 32 (2012) 16458-16465. doi:10.1523/JNEUROSCI.3987-12.2012.

[301] G. Bu, J. Cam, C. Zerbinatti, LRP in amyloid-beta production and metabolism., Ann. N. Y. Acad. Sci. 1086 (2006) 35-53. doi:10.1196/annals.1377.005.

[302] J.A. Cam, C. V Zerbinatti, J.M. Knisely, S. Hecimovic, Y. Li, G. Bu, The low density lipoprotein receptor-related protein $1 \mathrm{~B}$ retains beta-amyloid precursor protein at the cell surface and reduces amyloid-beta peptide production., J. Biol. Chem. 279 (2004) 2963929646. doi:10.1074/jbc.M313893200.

[303] T.A. Bayer, S. Schafer, A. Simons, A. Kemmling, T. Kamer, R. Tepest, A. Eckert, K. Schussel, O. Eikenberg, C. Sturchler-Pierrat, D. Abramowski, M. Staufenbiel, G. Multhaup, Dietary Cu stabilizes brain superoxide dismutase 1 activity and reduces amyloid Abeta production in APP23 transgenic mice., Proc. Natl. Acad. Sci. U. S. A. 100 
(2003) 14187-14192. doi:10.1073/pnas.2332818100.

[304] M.A. Cater, K.T. McInnes, Q.-X. Li, I. Volitakis, S. La Fontaine, J.F.B. Mercer, A.I. Bush, Intracellular copper deficiency increases amyloid- $\beta$ secretion by diverse mechanisms, Biochem. J. 412 (2008) 141-152.

[305] P. Faller, C. Hureau, G. La Penna, Metal ions and intrinsically disordered proteins and peptides: from Cu/Zn amyloid-beta to general principles., Acc. Chem. Res. 47 (2014) 2252-2259. doi:10.1021/ar400293h.

[306] S.C. Drew, K.J. Barnham, The heterogeneous nature of Cu2+ interactions with Alzheimer’s amyloid-beta peptide, Acc Chem Res. 44 (2011) 1146-1155. doi:10.1021/ar200014u.

[307] B. Alies, H. Eury, C. Bijani, L. Rechignat, P. Faller, C. Hureau, pH-Dependent Cu(II) Coordination to Amyloid- $\beta$ Peptide: Impact of Sequence Alterations, Including the H6R and D7N Familial Mutations., Inorg. Chem. 50 (2011) 11192-11201. doi:10.1021/ic201739n.

[308] K.L. Summers, K.M. Schilling, G. Roseman, K.A. Markham, N. V Dolgova, T. Kroll, D. Sokaras, G.L. Millhauser, I.J. Pickering, G.N. George, X-ray Absorption Spectroscopy Investigations of Copper (II) Coordination in the Human Amyloid $\beta$ Peptide, Inorg. Chem. (2019).

[309] V. Tõugu, A. Karafin, P. Palumaa, Binding of zinc(II) and copper(II) to the full-length Alzheimer's amyloid- $\beta$ peptide, J. Neurochem. 104 (2008) 1249-1259. doi:10.1111/j.1471-4159.2007.05061.x.

[310] C.S. Atwood, R.C. Scarpa, X. Huang, R.D. Moir, W.D. Jones, D.P. Fairlie, R.E. Tanzi, A.I. Bush, Characterization of copper interactions with alzheimer amyloid beta peptides: identification of an attomolar-affinity copper binding site on amyloid beta1-42., J. Neurochem. 75 (2000) 1219-1233.

[311] C.J. Sarell, C.D. Syme, S.E.J. Rigby, J.H. Viles, Copper(II) binding to amyloid-beta fibrils of Alzheimer's disease reveals a picomolar affinity: stoichiometry and coordination geometry are independent of Abeta oligomeric form., Biochemistry. 48 (2009) 43884402. doi:10.1021/bi900254n.

[312] L.Q. Hatcher, L. Hong, W.D. Bush, T. Carducci, J.D. Simon, Quantification of the Binding Constant of Copper(II) to the Amyloid-Beta Peptide, J. Phys. Chem. B. 112 (2008) 8160-8164. doi:10.1021/jp710806s. 
[313] I. Zawisza, M. Rózga, W. Bal, Affinity of copper and zinc ions to proteins and peptides related to neurodegenerative conditions (A $\beta$, APP, $\alpha$-synuclein, PrP), Coord. Chem. Rev. 256 (2012) 2297-2307. doi:10.1016/j.ccr.2012.03.012.

[314] G. Arena, G. Pappalardo, I. Sovago, E. Rizzarelli, Copper(II) interaction with amyloid- $\beta$ : Affinity and speciation, Coord. Chem. Rev. 256 (2012) 3-12.

doi:10.1016/j.ccr.2011.07.012.

[315] V. Tõugu, A. Karafin, K. Zovo, R.S. Chung, C. Howells, A.K. West, P. Palumaa, Zn(II)and $\mathrm{Cu}(\mathrm{II})$-induced non-fibrillar aggregates of amyloid- $\beta$ (1-42) peptide are transformed to amyloid fibrils, both spontaneously and under the influence of metal chelators, J. Neurochem. 110 (2009) 1784-1795. doi:10.1111/j.1471-4159.2009.06269.x.

[316] T. Miura, K. Suzuki, N. Kohata, H. Takeuchi, Metal binding modes of Alzheimer’s amyloid beta-peptide in insoluble aggregates and soluble complexes., Biochemistry. 39 (2000) 7024-7031.

[317] D. Drago, S. Bolognin, P. Zatta, Role of metal ions in the A $\beta$ oligomerization in Alzheimer's disease and in other neurological disorders, Curr. Alzheimer Res. 5 (2008) 500-507. doi:10.2174/156720508786898479.

[318] A.K. Sharma, S.T. Pavlova, J. Kim, J. Kim, L.M. Mirica, The effect of $\mathrm{Cu}(2+)$ and $\mathrm{Zn}(2+)$ on the A 342 peptide aggregation and cellular toxicity., Metallomics. 5 (2013) 1529-36. doi:10.1039/c3mt00161j.

[319] S.S. Leal, H.M. Botelho, C.M. Gomes, Metal ions as modulators of protein conformation and misfolding in neurodegeneration, Coord. Chem. Rev. 256 (2012) 2253-2270. doi:10.1016/j.ccr.2012.04.004.

[320] K. Ono, M.M. Condron, D.B. Teplow, Structure-neurotoxicity relationships of amyloid beta-protein oligomers., Proc. Natl. Acad. Sci. U. S. A. 106 (2009) 14745-14750. doi:10.1073/pnas.0905127106.

[321] J.I. Kourie, C.L. Henry, P. Farrelly, Diversity of amyloid beta protein fragment [1-40]formed channels., Cell. Mol. Neurobiol. 21 (2001) 255-284.

[322] M. Ramsden, Z. Henderson, H.A. Pearson, Modulation of Ca2+ channel currents in primary cultures of rat cortical neurones by amyloid beta protein (1-40) is dependent on solubility status., Brain Res. 956 (2002) 254-261.

[323] R. Bhatia, H. Lin, R. Lal, Fresh and globular amyloid beta protein (1-42) induces rapid cellular degeneration: evidence for AbetaP channel-mediated cellular toxicity., FASEB J. 
14 (2000) 1233-1243.

[324] H. Lin, R. Bhatia, R. Lal, Amyloid beta protein forms ion channels: implications for Alzheimer's disease pathophysiology., FASEB J. 15 (2001) 2433-2444. doi:10.1096/fj.01-0377com.

[325] A. Demuro, E. Mina, R. Kayed, S.C. Milton, I. Parker, C.G. Glabe, Calcium dysregulation and membrane disruption as a ubiquitous neurotoxic mechanism of soluble amyloid oligomers., J. Biol. Chem. 280 (2005) 17294-17300. doi:10.1074/jbc.M500997200.

[326] V. Minicozzi, F. Stellato, M. Comai, M.D. Serra, C. Potrich, W. Meyer-Klaucke, S. Morante, Identifying the Minimal Copper- and Zinc-binding Site Sequence in Amyloid- $\beta$ Peptides, J. Biol. Chem. . 283 (2008) 10784-10792. http://www.jbc.org/content/283/16/10784.abstract.

[327] M.K. Tiwari, K.P. Kepp, Pathogenic properties of Alzheimer's $\beta$-amyloid identified from structure-property patient-phenotype correlations, Dalt. Trans. 44 (2015) 2747-2754. doi:10.1039/c4dt03122a.

[328] W. Qiang, W.-M. Yau, Y. Luo, M.P. Mattson, R. Tycko, Antiparallel beta-sheet architecture in Iowa-mutant beta-amyloid fibrils., Proc. Natl. Acad. Sci. U. S. A. 109 (2012) 4443-4448. doi:10.1073/pnas.1111305109.

[329] A. Lomakin, D.B. Teplow, D.A. Kirschner, G.B. Benedek, Kinetic theory of fibrillogenesis of amyloid beta-protein., Proc. Natl. Acad. Sci. U. S. A. 94 (1997) 79427947.

[330] P. Seubert, C. Vigo-Pelfrey, F. Esch, M. Lee, H. Dovey, D. Davis, S. Sinha, M. Schlossmacher, J. Whaley, C. Swindlehurst, Isolation and quantification of soluble Alzheimer’s beta-peptide from biological fluids., Nature. 359 (1992) 325-327. doi:10.1038/359325a0.

[331] D. Galasko, L. Chang, R. Motter, C.M. Clark, J. Kaye, D. Knopman, R. Thomas, D. Kholodenko, D. Schenk, I. Lieberburg, B. Miller, R. Green, R. Basherad, L. Kertiles, M.A. Boss, P. Seubert, High cerebrospinal fluid tau and low amyloid beta42 levels in the clinical diagnosis of Alzheimer disease and relation to apolipoprotein E genotype., Arch. Neurol. 55 (1998) 937-945.

[332] S. Sinha, J.P. Anderson, R. Barbour, G.S. Basi, R. Caccavello, D. Davis, M. Doan, H.F. Dovey, N. Frigon, J. Hong, K. Jacobson-Croak, N. Jewett, P. Keim, J. Knops, I. Lieberburg, M. Power, H. Tan, G. Tatsuno, J. Tung, D. Schenk, P. Seubert, S.M. 
Suomensaari, S. Wang, D. Walker, J. Zhao, L. McConlogue, V. John, Purification and cloning of amyloid precursor protein [beta]-secretase from human brain, Nature. 402 (1999) 537-540. http://dx.doi.org/10.1038/990114.

[333] L.M. Munter, H. Sieg, T. Bethge, F. Liebsch, F.S. Bierkandt, M. Schleeger, H.J. Bittner, J. Heberle, N. Jakubowski, P.W. Hildebrand, G. Multhaup, Model peptides uncover the role of the beta-secretase transmembrane sequence in metal ion mediated oligomerization., $\mathrm{J}$. Am. Chem. Soc. 135 (2013) 19354-19361. doi:10.1021/ja410812r.

[334] C. Dingwall, A copper-binding site in the cytoplasmic domain of BACE1 identifies a possible link to metal homoeostasis and oxidative stress in Alzheimer's disease., Biochem. Soc. Trans. 35 (2007) 571-573. doi:10.1042/BST0350571.

[335] B. Angeletti, K.J. Waldron, K.B. Freeman, H. Bawagan, I. Hussain, C.C.J. Miller, K.-F. Lau, M.E. Tennant, C. Dennison, N.J. Robinson, C. Dingwall, BACE1 cytoplasmic domain interacts with the copper chaperone for superoxide dismutase- 1 and binds copper., J. Biol. Chem. 280 (2005) 17930-17937. doi:10.1074/jbc.M412034200.

[336] P. Hou, G. Liu, Y. Zhao, Z. Shi, Q. Zheng, G. Bu, H. Xu, Y. Zhang, Role of copper and the copper-related protein CUTA in mediating APP processing and A $\beta$ generation., Neurobiol. Aging. 36 (2015) 1310-1315. doi:10.1016/j.neurobiolaging.2014.12.005.

[337] F. Liebsch, M.R.P. Aurousseau, T. Bethge, H. McGuire, S. Scolari, A. Herrmann, R. Blunck, D. Bowie, G. Multhaup, Full-length cellular $\beta$-secretase has a trimeric subunit stoichiometry, and its sulfur-rich transmembrane interaction site modulates cytosolic copper compartmentalization, J. Biol. Chem. 292 (2017) 13258-13270.

[338] R.A. Cherny, C.S. Atwood, M.E. Xilinas, D.N. Gray, W.D. Jones, C. a. McLean, K.J. Barnham, I. Volitakis, F.W. Fraser, Y.S. Kim, X. Huang, L.E. Goldstein, R.D. Moir, J.T. Lim, K. Beyreuther, H. Zheng, R.E. Tanzi, C.L. Masters, A.I. Bush, Treatment with a copper-zinc chelator markedly and rapidly inhibits $\beta$-amyloid accumulation in Alzheimer’s disease transgenic mice, Neuron. 30 (2001) 665-676. doi:10.1016/S08966273(01)00317-8.

[339] M. Huang, S.-S. Xie, N. Jiang, J.-S. Lan, L.-Y. Kong, X.-B. Wang, Multifunctional coumarin derivatives: Monoamine oxidase B (MAO-B) inhibition, anti- $\beta$-amyloid (A $\beta$ ) aggregation and metal chelation properties against Alzheimer's disease, Bioorg. Med. Chem. Lett. 25 (2015) 508-513. doi:https://doi.org/10.1016/j.bmcl.2014.12.034.

[340] L. Huang, C. Lu, Y. Sun, F. Mao, Z. Luo, T. Su, H. Jiang, W. Shan, X. Li, Multitarget- 
Directed Benzylideneindanone Derivatives: Anti- $\beta$-Amyloid (A $\beta$ ) Aggregation, Antioxidant, Metal Chelation, and Monoamine Oxidase B (MAO-B) Inhibition Properties against Alzheimer’s Disease, J. Med. Chem. 55 (2012) 8483-8492. doi:10.1021/jm300978h.

[341] A.S. DeToma, J.-S. Choi, J.J. Braymer, M.H. Lim, Myricetin: A Naturally Occurring Regulator of Metal-Induced Amyloid- $\beta$ Aggregation and Neurotoxicity, ChemBioChem. 12 (2011) 1198-1201. doi:10.1002/cbic.201000790.

[342] J.-Y. Lee, J.E. Friedman, I. Angel, A. Kozak, J.-Y. Koh, The lipophilic metal chelator DP109 reduces amyloid pathology in brains of human beta-amyloid precursor protein transgenic mice., Neurobiol. Aging. 25 (2004) 1315-1321. doi:10.1016/j.neurobiolaging.2004.01.005.

[343] A. Venti, T. Giordano, P. Eder, A.I. Bush, D.K. Lahiri, N.H. Greig, J.T. Rogers, The integrated role of desferrioxamine and phenserine targeted to an iron-responsive element in the APP-mRNA 5'-untranslated region., Ann. N. Y. Acad. Sci. 1035 (2004) 34-48. doi:10.1196/annals.1332.003.

[344] M. Ho, D.E. Hoke, Y.J. Chua, Q.-X. Li, J.G. Culvenor, C. Masters, A.R. White, G. Evin, Effect of Metal Chelators on gamma-Secretase Indicates That Calcium and Magnesium Ions Facilitate Cleavage of Alzheimer Amyloid Precursor Substrate., Int. J. Alzheimers. Dis. 2011 (2010) 950932. doi:10.4061/2011/950932.

[345] W. Wu, P. Lei, Q. Liu, J. Hu, A.P. Gunn, M. Chen, Y. Rui, X. Su, Z. Xie, Y.-F. Zhao, A.I. Bush, Y. Li, Sequestration of copper from beta-amyloid promotes selective lysis by cyclen-hybrid cleavage agents., J. Biol. Chem. 283 (2008) 31657-31664. doi:10.1074/jbc.M804722200.

[346] L. Perrone, E. Mothes, M. Vignes, A. Mockel, C. Figueroa, M.-C. Miquel, M.-L. Maddelein, P. Faller, Copper transfer from $\mathrm{Cu}-\mathrm{A} \beta$ to human serum albumin inhibits aggregation, radical production and reduces A $\beta$ toxicity., Chembiochem. 11 (2010) 110118. doi:10.1002/cbic.200900474.

[347] S.K. Singh, P. Sinha, L. Mishra, S. Srikrishna, Neuroprotective Role of a Novel Copper Chelator against Abeta 42 Induced Neurotoxicity., Int. J. Alzheimers. Dis. 2013 (2013) 567128. doi:10.1155/2013/567128.

[348] J. Ceccom, F. Cosledan, H. Halley, B. Frances, J.M. Lassalle, B. Meunier, Copper chelator induced efficient episodic memory recovery in a non-transgenic Alzheimer's 
mouse model., PLoS One. 7 (2012) e43105. doi:10.1371/journal.pone.0043105.

[349] Y. Miller, B. Ma, R. Nussinov, Metal binding sites in amyloid oligomers: Complexes and mechanisms, Coord. Chem. Rev. 256 (2012) 2245-2252.

doi:http://dx.doi.org/10.1016/j.ccr.2011.12.022.

[350] M. Rana, A.K. Sharma, Cu and Zn interactions with A $\beta$ peptides: Consequence of coordination on aggregation and formation of neurotoxic soluble $A \beta$ oligomers, Metallomics. 11 (2019) 64-84.

[351] D.G. Smith, R. Cappai, K.J. Barnham, The redox chemistry of the Alzheimer's disease amyloid $\beta$ peptide, Biochim. Biophys. Acta - Biomembr. 1768 (2007) 1976-1990. doi:http://dx.doi.org/10.1016/j.bbamem.2007.02.002.

[352] A.N. Pham, G. Xing, C.J. Miller, T.D. Waite, Fenton-like copper redox chemistry revisited: hydrogen peroxide and superoxide mediation of copper-catalyzed oxidant production, J. Catal. 301 (2013) 54-64.

[353] P.N. Lacor, M.C. Buniel, L. Chang, S.J. Fernandez, Y. Gong, K.L. Viola, M.P. Lambert, P.T. Velasco, E.H. Bigio, C.E. Finch, G.A. Krafft, W.L. Klein, Synaptic targeting by Alzheimer's-related amyloid beta oligomers., J. Neurosci. 24 (2004) 10191-10200. doi:10.1523/JNEUROSCI.3432-04.2004.

[354] J. Han, H.J. Lee, K.Y. Kim, S.J.C. Lee, J.-M. Suh, J. Cho, J. Chae, M.H. Lim, Tuning Structures and Properties for Developing Novel Chemical Tools toward Distinct Pathogenic Elements in Alzheimer’s Disease, ACS Chem. Neurosci. 9 (2018) 800-808. doi:10.1021/acschemneuro.7b00454.

[355] M.G. Savelieff, A.S. DeToma, J.S. Derrick, M.H. Lim, The ongoing search for small molecules to study metal-associated amyloid-beta species in Alzheimer’s disease., Acc. Chem. Res. 47 (2014) 2475-2482. doi:10.1021/ar500152x.

[356] S. Lee, X. Zheng, J. Krishnamoorthy, M.G. Savelieff, H.M. Park, J.R. Brender, J.H. Kim, J.S. Derrick, A. Kochi, H.J. Lee, C. Kim, A. Ramamoorthy, M.T. Bowers, M.H. Lim, Rational Design of a Structural Framework with Potential Use to Develop Chemical Reagents That Target and Modulate Multiple Facets of Alzheimer's Disease, J. Am. Chem. Soc. 136 (2014) 299-310. doi:10.1021/ja409801p.

[357] Y. Ji, H.J. Lee, M. Kim, G. Nam, S.J.C. Lee, J. Cho, C.-M. Park, M.H. Lim, Strategic Design of 2,2'-Bipyridine Derivatives to Modulate Metal-Amyloid- $\beta$ Aggregation, Inorg. Chem. 56 (2017) 6695-6705. doi:10.1021/acs.inorgchem.7b00782. 
[358] S. Hong, Y.K. Go, J.S. Derrick, S. Han, J. Kim, M.H. Lim, S.H. Kim, Advanced Electron Paramagnetic Resonance Studies of a Ternary Complex of Copper, Amyloid- $\beta$, and a Chemical Regulator, Inorg. Chem. 57 (2018) 12665-12670.

doi:10.1021/acs.inorgchem.8b01824.

[359] A.M. Mancino, S.S. Hindo, A. Kochi, M.H. Lim, Effects of Clioquinol on MetalTriggered Amyloid- $\beta$ Aggregation Revisited, Inorg. Chem. 48 (2009) 9596-9598. doi:10.1021/ic9014256.

[360] D. Attwell, S.B. Laughlin, An energy budget for signaling in the grey matter of the brain, J. Cereb. Blood Flow Metab. 21 (2001) 1133-1145.

[361] M.E. Raichle, D.A. Gusnard, Appraising the brain’s energy budget, Proc. Natl. Acad. Sci. 99 (2002) 10237-10239.

[362] C. Zhang, R.A. Rissman, J. Feng, Characterization of ATP alternations in an Alzheimer's disease transgenic mouse model., J. Alzheimers. Dis. 44 (2015) 375-378. doi:10.3233/JAD-141890.

[363] A.R. Hipkiss, On the Relationship between Energy Metabolism, Proteostasis, Aging and Parkinson’s Disease: Possible Causative Role of Methylglyoxal and Alleviative Potential of Carnosine, Aging Dis. 8 (2017) 334-345. doi:10.14336/AD.2016.1030.

[364] F. Yin, A. Boveris, E. Cadenas, Mitochondrial energy metabolism and redox signaling in brain aging and neurodegeneration, Antioxid. Redox Signal. 20 (2014) 353-371.

[365] W.S. Liang, E.M. Reiman, J. Valla, T. Dunckley, T.G. Beach, A. Grover, T.L. Niedzielko, L.E. Schneider, D. Mastroeni, R. Caselli, W. Kukull, J.C. Morris, C.M. Hulette, D. Schmechel, J. Rogers, D.A. Stephan, Alzheimer’s disease is associated with reduced expression of energy metabolism genes in posterior cingulate neurons, Proc. Natl. Acad. Sci. . 105 (2008) 4441-4446. http://www.pnas.org/content/105/11/4441.abstract.

[366] D. Kapogiannis, M.P. Mattson, Disrupted energy metabolism and neuronal circuit dysfunction in cognitive impairment and Alzheimer's disease, Lancet Neurol. 10 (2011) 187-198. doi:10.1016/S1474-4422(10)70277-5.

[367] S. Hoyer, Brain glucose and energy metabolism abnormalities in sporadic Alzheimer disease. Causes and consequences: an update, Exp. Gerontol. 35 (2000) 1363-1372. doi:http://dx.doi.org/10.1016/S0531-5565(00)00156-X.

[368] R.H. Swerdlow, Brain aging, Alzheimer’s disease, and mitochondria, Biochim. Biophys. Acta - Mol. Basis Dis. 1812 (2011) 1630-1639. doi:10.1016/j.bbadis.2011.08.012. 
[369] C. Carvalho, S.C. Correia, R.X. Santos, S. Cardoso, P.I. Moreira, T.A. Clark, X. Zhu, M.A. Smith, G. Perry, Role of mitochondrial-mediated signaling pathways in Alzheimer disease and hypoxia, J. Bioenerg. Biomembr. 41 (2009) 433-440. doi:10.1007/s10863009-9247-1.

[370] L.J. Martin, Mitochondrial pathobiology in ALS., J. Bioenerg. Biomembr. 43 (2011) 56979. doi:10.1007/s10863-011-9395-y.

[371] K.P. Kepp, P. Dasmeh, A model of proteostatic energy cost and its use in analysis of proteome trends and sequence evolution., PLoS One. 9 (2014) e90504. doi:10.1371/journal.pone.0090504.

[372] K.P. Kepp, Genotype-Property Patient-Phenotype Relations Suggest that Proteome Exhaustion Can Cause Amyotrophic Lateral Sclerosis, PLoS One. 10 (2015) e0118649. doi:10.1371/journal.pone.0118649.

[373] J.M. Walshe, E. Waldenström, V. Sams, H. Nordlinder, K. Westermark, Abdominal malignancies in patients with Wilson’s disease, Qjm. 96 (2003) 657-662.

[374] M. Akil, G.J. Brewer, Psychiatric and behavioral abnormalities in Wilson's disease., Adv. Neurol. 65 (1995) 171-178.

[375] M.G. Carta, O. Sorbello, M.F. Moro, K.M. Bhat, E. Demelia, A. Serra, G. Mura, F. Sancassiani, M. Piga, L. Demelia, Bipolar disorders and Wilson’s disease, BMC Psychiatry. 12 (2012) 52.

[376] S.K. Das, K. Ray, Wilson’s disease: an update, Nat. Rev. Neurol. 2 (2006) 482.

[377] O. Bandmann, K.H. Weiss, S.G. Kaler, Wilson's disease and other neurological copper disorders, Lancet Neurol. 14 (2015) 103-113.

[378] W. Oder, G. Grimm, H. Kollegger, P. Ferenci, B. Schneider, L. Deecke, Neurological and neuropsychiatric spectrum of Wilson's disease: a prospective study of 45 cases, J. Neurol. 238 (1991) 281-287.

[379] K. Srinivas, S. Sinha, A.B. Taly, L.K. Prashanth, G.R. Arunodaya, Y.C.J. Reddy, S. Khanna, Dominant psychiatric manifestations in Wilson's disease: a diagnostic and therapeutic challenge!, J. Neurol. Sci. 266 (2008) 104-108.

[380] P.C. Zimbrean, M.L. Schilsky, Psychiatric aspects of Wilson disease: a review, Gen. Hosp. Psychiatry. 36 (2014) 53-62.

[381] M. Südmeyer, A. Saleh, L. Wojtecki, M. Cohnen, J. Gross, M. Ploner, H. Hefter, L. Timmermann, A. Schnitzler, Wilson’s disease tremor is associated with magnetic 
resonance imaging lesions in basal ganglia structures, Mov. Disord. Off. J. Mov. Disord. Soc. 21 (2006) 2134-2139.

[382] H. Barthel, W. Hermann, R. Kluge, S. Hesse, D.R. Collingridge, A. Wagner, O. Sabri, Concordant pre-and postsynaptic deficits of dopaminergic neurotransmission in neurologic Wilson disease, Am. J. Neuroradiol. 24 (2003) 234-238.

[383] S.H. Hahn, S.Y. Lee, Y.-J. Jang, S.N. Kim, H.C. Shin, S.Y. Park, H.S. Han, E.S. Yu, H.W. Yoo, J.S. Lee, Pilot study of mass screening for Wilson’s disease in Korea, Mol. Genet. Metab. 76 (2002) 133-136.

[384] A.J. Coffey, M. Durkie, S. Hague, K. McLay, J. Emmerson, C. Lo, S. Klaffke, C.J. Joyce, A. Dhawan, N. Hadzic, A genetic study of Wilson's disease in the United Kingdom, Brain. 136 (2013) 1476-1487.

[385] S. Bucossi, R. Polimanti, M. Ventriglia, S. Mariani, M. Siotto, F. Ursini, L. Trotta, F. Scrascia, A. Callea, F. Vernieri, Intronic rs2147363 variant in ATP7B transcription factorbinding site associated with Alzheimer's disease, J. Alzheimer’s Dis. 37 (2013) 453-459.

[386] R. Squitti, M. Siotto, I. Ivanova, M. Rongioletti, Chapter 42 - ATP7B and Alzheimer Disease, in: N. Kerkar, E.A.B.T.-C. and T.P. on W.D. Roberts (Eds.), Academic Press, 2019: pp. 427-436. doi:https://doi.org/10.1016/B978-0-12-810532-0.00042-2.

[387] J. Pujol, R. Fenoll, D. Macià, G. Martínez-Vilavella, M. Alvarez-Pedrerol, I. Rivas, J. Forns, J. Deus, L. Blanco-Hinojo, X. Querol, J. Sunyer, Airborne copper exposure in school environments associated with poorer motor performance and altered basal ganglia, Brain Behav. 6 (2016) e00467. doi:10.1002/brb3.467.

[388] R. Squitti, F. Tecchio, M. Ventriglia, The role of copper in human diet and risk of dementia, Curr. Nutr. Rep. 4 (2015) 114-125.

[389] C.M. Ackerman, C.J. Chang, Copper signaling in the brain and beyond, J. Biol. Chem. 293 (2018) 4628-4635.

[390] K.L. Viola, P.T. Velasco, W.L. Klein, Why Alzheimer's is a disease of memory: the attack on synapses by A beta oligomers (ADDLs)., J. Nutr. Health Aging. 12 (2008) 51S7S.

[391] B. Alies, E. Renaglia, M. Rózga, W. Bal, P. Faller, C. Hureau, Cu (II) affinity for the Alzheimer’s peptide: Tyrosine fluorescence studies revisited, Anal. Chem. 85 (2013) 1501-1508.

[392] N. Doreulee, Y. Yanovsky, H.L. Haas, Suppression of long-term potentiation in 
hippocampal slices by copper, Hippocampus. 7 (1997) 666-669.

[393] A. Goldschmith, C. Infante, J. Leiva, E. Motles, M. Palestini, Interference of chronically ingested copper in long-term potentiation (LTP) of rat hippocampus, Brain Res. 1056 (2005) 176-182.

[394] J. Leiva, M. Palestini, C. Infante, A. Goldschmidt, E. Motles, Copper suppresses hippocampus LTP in the rat, but does not alter learning or memory in the morris water maze, Brain Res. 1256 (2009) 69-75.

[395] Y. Nishida, The chemical process of oxidative stress by copper(II) and iron(III) ions in several neurodegenerative disorders, Monatshefte Für Chemie - Chem. Mon. 142 (2011) 375-384. doi:10.1007/s00706-010-0444-8.

[396] G. Multhaup, Amyloid precursor protein, copper and Alzheimer’s disease, Biomed. Pharmacother. 51 (1997) 105-111.

[397] P. Ip, V. Mulligan, A. Chakrabartty, ALS-causing SOD1 mutations promote production of copper-deficient misfolded species, J. Mol. Biol. 409 (2011) 839-852. doi:10.1016/j.jmb.2011.04.027.

[398] A. Nordlund, L. Leinartaite, Functional features cause misfolding of the ALS-provoking enzyme SOD1, Proc. Natl. Acad. Sci. U. S. A. 106 (2009) 9667-9672. http://www.pnas.org/content/106/24/9667.short (accessed June 28, 2014).

[399] J. Perry, D. Shin, E. Getzoff, J. Tainer, The structural biochemistry of the superoxide dismutases, Biochim. Biophys. Acta. 1804 (2010) 245-262. doi:10.1016/j.bbapap.2009.11.004.

[400] J.R. Connor, P. Tucker, M. Johnson, B. Snyder, Ceruloplasmin levels in the human superior temporal gyrus in aging and Alzheimer's disease, Neurosci. Lett. 159 (1993) 8890. doi:https://doi.org/10.1016/0304-3940(93)90805-U.

[401] A.I. Bush, The metallobiology of Alzheimer's disease, Trends Neurosci. 26 (2003) 207214. doi:https://doi.org/10.1016/S0166-2236(03)00067-5.

[402] S. Miyata, H. Nagata, S. Yamao, S. Nakamura, M. Kameyama, Dopamine- $\beta$-hydroxylase activities in serum and cerebrospinal fluid of aged and demented patients, J. Neurol. Sci. 63 (1984) 403-409. doi:https://doi.org/10.1016/0022-510X(84)90163-1.

[403] C.J. Maynard, A.I. Bush, C.L. Masters, R. Cappai, Q.-X. Li, Metals and amyloid-beta in Alzheimer’s disease, Int. J. Exp. Pathol. 86 (2005) 147-159. doi:10.1111/j.09599673.2005.00434.x. 
[404] M.E. Letelier, A.M. Lepe, M. Faúndez, J. Salazar, R. Marín, P. Aracena, H. Speisky, Possible mechanisms underlying copper-induced damage in biological membranes leading to cellular toxicity, Chem. Biol. Interact. 151 (2005) 71-82.

[405] L. Guilloreau, S. Combalbert, A. Sournia-Saquet, H. Mazarguil, P. Faller, Redox Chemistry of Copper-Amyloid- $\beta$ : The Generation of Hydroxyl Radical in the Presence of Ascorbate is Linked to Redox-Potentials and Aggregation State, ChemBioChem. 8 (2007) 1317-1325. doi:10.1002/cbic.200700111.

[406] G.J. Brewer, Copper toxicity in Alzheimer's disease: cognitive loss from ingestion of inorganic copper, J. Trace Elem. Med. Biol. 26 (2012) 89-92.

[407] G.J. Brewer, The risks of copper toxicity contributing to cognitive decline in the aging population and to Alzheimer's disease, J. Am. Coll. Nutr. 28 (2009) 238-242.

[408] G.J. Brewer, Copper-2 hypothesis for causation of the current Alzheimer's disease epidemic together with dietary changes that enhance the epidemic, Chem. Res. Toxicol. 30 (2017) 763-768.

[409] A. Saghazadeh, M. Mahmoudi, A. Meysamie, M. Gharedaghi, G.W. Zamponi, N. Rezaei, Possible role of trace elements in epilepsy and febrile seizures: a meta-analysis, Nutr. Rev. 73 (2015) 760-779.

[410] F. Zhou, F. Wu, S. Zou, Y. Chen, C. Feng, G. Fan, Dietary, nutrient patterns and blood essential elements in Chinese children with ADHD, Nutrients. 8 (2016) 352.

[411] S. Alemany, N. Vilor-Tejedor, M. Bustamante, M. Álvarez-Pedrerol, I. Rivas, J. Forns, X. Querol, J. Pujol, J. Sunyer, Interaction between airborne copper exposure and ATP7B polymorphisms on inattentiveness in scholar children, Int. J. Hyg. Environ. Health. 220 (2017) 51-56. 